\title{
Virtual Approach to the Comparative Analysis of Biomaterials Used in Endodontic Treatment
}

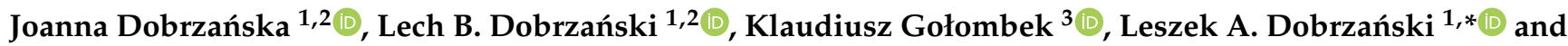 \\ Anna D. Dobrzańska-Danikiewicz ${ }^{4}$ (D) \\ 1 Medical and Dental Engineering Centre for Research, Design and Production ASKLEPIOS, \\ 13 D Krolowej Bony St., 44-100 Gliwice, Poland; joanna.dobrzanska@centrumasklepios.pl (J.D.); \\ dobrzanski@centrumasklepios.pl (L.B.D.) \\ 2 Medical and Dental Centre SOBIESKI, 12/1 King Jan III Sobieski St., 44-100 Gliwice, Poland \\ 3 Faculty of Mechanical Engineering, Silesian University of Technology, 18 A Konarski St., \\ 44-100 Gliwice, Poland; klaudiusz.golombek@polsl.pl \\ 4 Faculty of Mechanical Engineering, University of Zielona Góra, 4 Prof. Z. Szafrana St., \\ 65-516 Zielona Góra, Poland; anna.dobrzanska.danikiewicz@gmail.com \\ * Correspondence: leszek.dobrzanski@centrumasklepios.pl
}

Citation: Dobrzańska, J.; Dobrzański, L.B.; Gołombek, K.; Dobrzański, L.A.; Dobrzańska-Danikiewicz, A.D. Virtual Approach to the Comparative Analysis of Biomaterials Used in Endodontic Treatment. Processes 2021, 9, 926. https://doi.org/10.3390/ pr9060926

Academic Editor: Tao Sun

Received: 30 April 2021

Accepted: 21 May 2021

Published: 25 May 2021

Publisher's Note: MDPI stays neutral with regard to jurisdictional claims in published maps and institutional affiliations.

Copyright: (c) 2021 by the authors. Licensee MDPI, Basel, Switzerland. This article is an open access article distributed under the terms and conditions of the Creative Commons Attribution (CC BY) license (https:/ / creativecommons.org/licenses/by/ $4.0 /)$.
Abstract: The importance of endodontics is presented within our own concept of Dentistry Sustainable Development (DSD) consisting of three inseparable elements; i.e., Advanced Interventionist Dentistry 4.0 (AID 4.0), Global Dental Prevention (GDP), and the Dentistry Safety System (DSS) as a polemic, with the hypothesis of the need to abandon interventionist dentistry in favour of the domination of dental prevention. In view of the numerous systemic complications of caries that affect 3-5 billion people globally, endodontic treatment effectively counteracts them. Regardless of this, the prevention of oral diseases should be developed very widely, and in many countries dental care should reach the poorest sections of society. The materials and methods of clinical management in endodontic procedures are characterized. The progress in the field of filling materials and techniques for the development and obturation of root canals is presented. The endodontics market is forecast to reach USD 2.1 billion in 2026, with a CAGR of $4.1 \%$. The most widely used and recognized material for filling root canals is gutta-percha, recognized as the "gold standard". An alternative is a synthetic thermoplastic filler material based on polyester materials, known mainly under the trade name Resilon. There are still sceptical opinions about the need to replace gutta-percha with this synthetic material, and many dentists still believe that this material cannot compete with guttapercha. The results of studies carried out so far do not allow for the formulation of a substantively and ethically unambiguous view that gutta-percha should be replaced with another material. There is still insufficient clinical evidence to formulate firm opinions in this regard. In essence, materials and technologies used in endodontics do not differ from other groups of materials, which justifies using material engineering methodology for their research. Therefore, a detailed methodological approach is presented to objectify the assessment of endodontic treatment. Theoretical analysis was carried out using the methods of procedural benchmarking and comparative analysis with the use of contextual matrices to virtually optimize the selection of materials, techniques for the development and obturation of root canals, and methods for assessing the effectiveness of filling, which methods are usually used, e.g., in management science, and especially in foresight research as part of knowledge management. The results of these analyses are presented in the form of appropriate context matrices. The full usefulness of the research on the effectiveness and tightness of root canal filling using scanning electron microscopy is indicated. The analysis results are a practical application of the so-called "digital twins" approach concerning the virtual comparative analysis of biomaterials used in endodontic treatment.

Keywords: dentistry; endodontics; filling materials; sealants; obturation; gutta-percha; Resilon; procedural benchmarking; comparative matrices; virtual approach; digital twin; scanning electron microscopy 


\section{The Importance of Endodontics in the General Concept of Sustainable Dentistry Development}

The authors' work [1] presents the concept of Dentistry Sustainable Development (DSD > 2020) consisting of three inseparable elements; i.e., Advanced Interventionist Dentistry 4.0 (AID 4.0), Global Dental Prevention (GDP), and the Dentistry Safety System (DSS). The concept of Dentistry Sustainable Development and the authors' view on this subject is a polemic, with the main part of the thoughts contained in the series of two papers [2,3] promoting the hypothesis regarding the need to abandon interventionist dentistry, excluding therapeutic activities undertaken by dentists for the domination of dental prevention. It is impossible to agree with the approach that one should completely abandon interventionist dentistry in favour of the universally dominant prevention, if only because in many countries, e.g., due to the socio-economic situation, widespread lack of oral hygiene or eating habits, such a postulate is highly unlikely to be implemented. Treating caries and periodontal diseases is of great importance due to the scale of these diseases of the oral cavity, which currently affect $3-5$ billion people in the world [1]. Dental caries is the most common infectious disease globally. It includes interactions between bacterial biofilm and the surface of teeth, saliva, and genes; dietary carbohydrates, including sugars and starches; and the influence of behavioural, social, and psychological factors [4-6]. There are six countries with the most common caries in the 5-14 age group, including Kyrgyzstan, Uzbekistan, Romania, Bulgaria, Poland, and Ecuador [7]. The countries most affected by this disease in the entire age range also include France, Spain, Iceland, Greece, and Georgia [1].

Untreated dental caries is the direct cause of many systemic complications that place enormous pressure on health care systems and health insurance and disruptions in labour markets in all countries. The numerous complications of this type include, among others, nephritis, bacterial pneumonia, rheumatoid arthritis, endocarditis, ischemic heart disease, brain abscess, osteoporosis, premature delivery, reduction in infant birth weight, and even direct death of the patient [8-13]. Because tooth extraction caused by caries is often unavoidable, including due to the ineffectiveness of endodontic treatment, it can lead to partial or even complete toothlessness. Apart from the obvious loss of aesthetic value and eating ailments, toothlessness resulting from caries causes many systemic diseases [14-28], including even direct shortening of human life, cardiovascular diseases, heart failure, ischemic heart disease, hypertension and stroke, some cancers, diabetes, insulin independence, kidney disease and rheumatoid arthritis, gastritis, duodenal ulcer, pancreatic diseases (including tumours), neoplastic changes of the oesophagus and upper gastrointestinal tract, unfavourable course of pregnancy, mood and neurocognitive disorders, obstructive sleep apnea, cervical spine pain, migraine and headaches, disorders of cerebrospinal fluid metabolism and changes in the hippocampus in the elderly [29-35] and related spatial and episodic memory disorders, exacerbating symptoms of multiple sclerosis, and increasing the risk of dementia in general. The mentioned aspects fully justify the necessity of caries treatment.

The most important risk factors contributing to caries include excessive consumption of sugars, insufficient saliva flow, hygiene negligence, fluoride deficiency during daily tooth brushing, socio-economic degradation due to nutritional deficiencies causing deformation of the teeth, and lack of proper dental care [1]. Accurate and professional dental care reduces the risk of developing caries in every patient, which is presented schematically by the caries development pyramid (CDP), from Background Level Care (BLC) through Preventive Treatment Option (PTO) to Operative Treatment Option (OTO) (Figure 1). The 5D Caries Management Cycle Rules (CMCR), by analogy to the Deming Plan-Do-CheckAct behavioural approach, is presented in Figure 1c. Before cavitation symptoms become apparent, preventive measures should be taken to detect caries at the earliest possible stages of the disease (Figure 1d), with proper risk assessment and determination of adequate actions with an appropriate frequency of reminders [36-39]. 


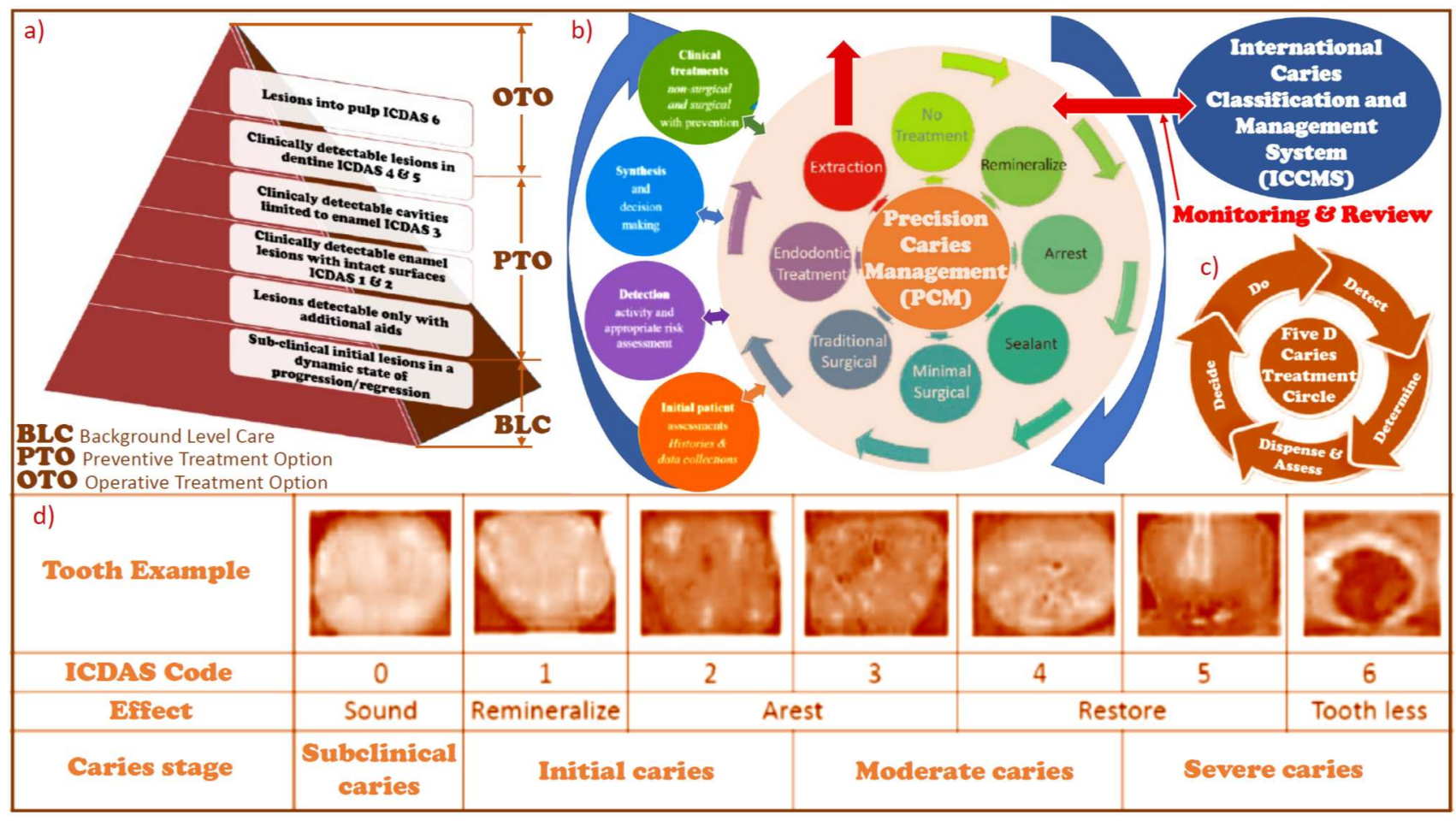

Figure 1. Diagram: (a) CDP caries development pyramid; (b) the Precision Caries Management (PCM) in cooperation with the International Caries Classification and Management System (ICCMS); (c) the 5D Caries Management Cycle Rules (CMCRs); (d) the International Caries Detection and Assessment System (ICDAS) application.

Visually, changes in enamel, dentine, and pulp allow for the separation of three primary grades of caries severity [40,41]. Work to date for over a century [42] has led to the development of the so-called "caries continuum". According to the International Caries Detection and Assessment System (ICDAS) [43-46], classification is evidence-based and oriented towards the prevention, detection, and evaluation of the stages of caries. The International Caries Classification and Management System (ICCMS) [47-50] is useful for improving long-term caries outcomes in conjunction with the Precision Caries Management (Figure 1b).

Dentists treat patients while actively preventing the spread of the previously mentioned serious systemic complications. The carefully performed endodontic treatment eliminates many of the risks as mentioned above and allows for a relatively long time to keep healed teeth in the patient's mouth, preventing complications, as well as partial or even complete toothlessness. After eight years from the end of endodontic treatment, in only $3 \%$ of cases, there are periapical changes such as cysts or granulomas [51], although in $90 \%$ of cases, these changes are caused by errors in the preparation and filling of root canals [52-56], as well as a crown or root fractures or other iatrogenic factors [57]. It is highly inappropriate to discredit the dentist community by criticizing the alleged approach in the slogan "drilling, filling, and billing" presented in the public discourse [58]. The authors remain convinced that this is a substantive manifestation of populism and trivialization of the real role of dentistry, especially endodontic treatment, or even contempt for such work, and a fundamentally inaccurate finding. Of course, the development of a root canal can be called drilling, while obturation with suitable material can be called filling. Dental services in many countries are in the private sector, so the patient has to finance all treatment costs. However, that is not a reason to mock this situation. These are serious medical activities, and treatments that are essentially cosmetological constitute a narrow range of activities of the dental community, although they most likely take place. However, they are not the motivation for the statistically overwhelming activity undertaken by dentists for the benefit of patients and in the name of well-understood ethical obligations of a dentist. Such an 
assessment must be surprising, especially as it comes from within the dentist community. There is every reason to believe that disseminating such false information is an ethical tort.

Although probably insufficiently developed, an important aspect of dentists' activity, especially in countries with low economic levels, is prevention. There is no doubt that prevention should be developed very widely. Dental care should cover all social strata, including the poorest and preferably in all countries, including in the original concept of the sustainable development of dentistry [1]. However, the facts seem to indicate that in many countries, especially low-income countries (LICs), this postulate is impossible to meet to a large extent or even at all.

An important part in the development of dentistry $[1,10]$ is to ensure the safety of dentists and dental staff in the face of the COVID-19 disease pandemic caused by the transmission of the SARS-CoV-2 coronavirus. The dentist is constantly exposed to infection because they are doing their job in the patient's respiratory tract. The issue was widely discussed in the authors' work [10], which also presented the authors' technical solution serving this purpose [59]. This aspect of the endodontist's work was also highlighted in $[60,61]$.

The basis of many therapeutic activities undertaken by dentists is close cooperation with the engineering and technical environment. In addition to the use of numerous devices, they range from a dental unit with a dental chair, through modern medical diagnosis methods using conical beam computed tomography (CBCT) and intraoral and extraoral scanning, to a wide range related to Dentistry $4.0[62,63]$ as an activity within Industry 4.0. The centres for producing dental prosthetic restorations fit into this idea as smart factories [62-98].

Cooperation in the field of conservative dentistry and endodontics also requires wide participation in engineering and technical activities, including proper selection of filling materials, sealants, and appropriate techniques for the development of the root canal and obturation, requiring the use of various instruments and tools. This paper aims to develop and present the methodological assumptions of the virtual comparative analysis of biomaterials used in endodontic treatment, including the production and selection of filling and sealing materials; the selection of dental devices and tools, including specialized tools; the selection and application of the technology for the development and obturation of the root canal; and assessment effectiveness and tightness of root canal filling as a result of endodontic treatment.

\section{General Characteristics of Materials and Clinical Procedures in Endodontic Treatment}

Precision Caries Management (PCM) involves making the right decisions depending on the caries stage established based on the International Caries Detection and Assessment System (ICDAS) (Figure 1). Each decision is based on the evidence obtained from a thorough dental examination by a dentist. Dental pulp attacked by caries bacteria causes pain, and dental intervention becomes indispensable. As it means caries advancement above the second stage according to ICDAS, it is necessary to start endodontic treatment [99-101] because it is simply too late for any prevented treatment. This is especially true of the maxillary and mandibular incisors of the first molars, most affected by endodontic diseases [102]. Keeping the tooth functional when it is no longer possible to keep it alive is the basis of the conventional approach that prescribes endodontic treatment, which is the subject of this paper. Of course, an alternative could be extracting a diseased tooth, but dentists prefer endodontic treatment for pragmatic and ethical reasons [103,104]. The paradigm shift of this approach leads to revascularization and regenerative endodontic procedures. Regenerative endodontics aims to create and deliver tissues to replace the diseased and traumatized tooth pulp. Although it is a breakthrough approach, it should be expected to become real. It will bring tremendous benefits to patients, regardless of the scale of the costs incurred, as it offers a chance to restore the natural function of the teeth instead of surgical placement of implants or even artificial dentures. This problem is 
beyond the scope of these considerations and is presented in more detail in the literature review $[105,106]$.

Endodontic treatment aims to leave the tooth in the mouth and prevent, and preferably eliminate, apical periodontitis [107]. This treatment consists of preparing the root canal by removing the pulp of the tooth and ensuring the best hermetization of the root canal after introducing replacement filling material and after prior disinfecting and shaping the canal. The selection of appropriate tools is important [108]. By introducing filling material, the tooth's hard tissues are directly restored, and the living tissue is replaced with a filling [109]. It is necessary coronally, with lateral and apical sealing of the previously infected and then prepared root canal of the tooth. It prevents the spread of bacteria with possible toxins towards the root tip [110-112] and saliva [113].

In this way, a tooth treated endodontically may continue to function in the oral cavity, even though it has been deprived of a viable intraroot structure. The filling material should meet numerous expectations: it should be biocompatible, prevent bacterial growth and preferably be bactericidal, be sterile, adapt well to the geometrical features of the prepared root canal, allow for easy removal if it is necessary to repeat endodontic treatment [114,115], and not cause adverse aesthetic effects; e.g., tooth discolouration [115-117]. Preferably, the filling material enhances the strength of the prepared tooth root [118].

Progress in filling materials and techniques for the development and obturation of root canals is made systematically, and newer materials are introduced [119-125] (Figure 2). However, the pace of these changes is not significant. Significant changes have been observed over the past half-century, and some of the methods or materials listed in Figure 2 may now be of historical importance.
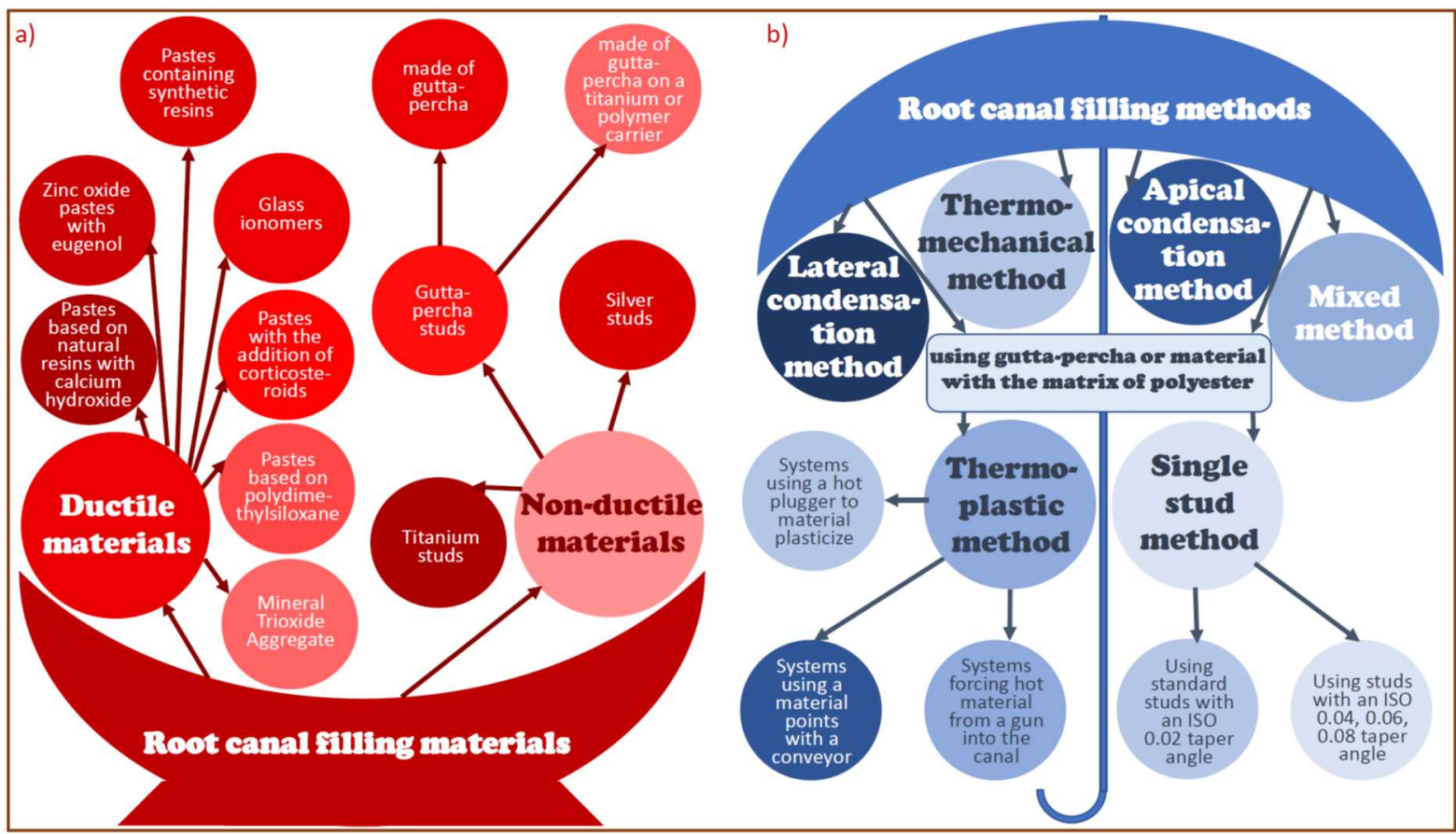

Figure 2. Scheme: (a) ikebana full of all types of root canal filling materials; (b) umbrella surrounding all types of root canal filling methods.

Apart from the substantive literature reports grouped in Figure 2 in the form of ikebana materials used in endodontics and the umbrella of obstructive techniques, an important indication for the assessment of the development of endodontics on a global scale is the results of the analysis of global markets related to this field of health protection. There are several main factors determining the growth of the endodontic market in the world. Undoubtedly, one of the most important factors is the increasing incidence of caries 
and other oral diseases. Together with a detailed analysis of the territorial distribution of caries and other diseases of the oral cavity, this issue was presented in the authors' study [1]. The increase in the incidence of caries and the consequent need for endodontic treatment is strongly associated with the rapid growth of the geriatric population and the ageing of societies. According to data provided by WHO, it is estimated that by 2050 the global population of elderly people will reach approximately 2 billion worldwide, when in 2010 it was already around 524 million people [126]. The rapid growth takes place in highly developed countries, including in the United States, Japan, and Europe in Italy, Germany, and the United Kingdom. According to the US Census Bureau, the US population of people aged 65 and over will increase more than twice between 2011 and 2050, from around 40 million to approximately 89 million [126]. The knowledge about oral hygiene and health in low-income groups is low, which inevitably affects the lack or inadequate level of prevention of oral diseases [127], which affects huge numbers of people worldwide. At the same time, higher- and high-income societies systematically increase awareness of oral hygiene and the need to treat oral diseases [128], which is an important driver of the growth of the endodontic market. This is accompanied by an increase in government support in many countries to promote awareness of dental disorders and diseases [128] due to the noticeable negative impact of these diseases on the macroeconomic situation in various countries and the related increasing expenditure on dental care. Such government initiatives in the last few years include, for example, the National Tobacco Control Program (NTCP) implemented in India, implementing the World Health Organization Framework Convention on Tobacco Control. In the UK, the National Health System accredits physicians to provide endodontic and oral surgery services not yet covered by the Standard General Dental Services (GDS). The growth of the endodontic market in the world is influenced by the growing number of dentists and dental offices. Technological progress and modernization of endodontic devices resulted in disseminating improved rotary equipment for the development of root canals and reducing iatrogenic errors during this treatment. The improvement of root canal development is significantly influenced by the restriction of conventional stainless-steel hand-file systems in favour of a significant increase in the use of reciprocating nickel-titanium rotary files [127].

The corollary of this is a significant improvement in root canal preparation. An overall increase in consumers' disposable income is enabling them to increase their dental care spending and increase dental tourism, especially in developing countries due to the availability of low-cost services, including transportation, accommodation, and dental care, including in India, Mexico, and Brazil [127]. There is also a huge untapped market potential in emerging countries such as South Africa and India, where the demand for dental services is growing, including motivations resulting not from health but also aesthetic reasons [128]. The opposite effect is the high cost of dental products, limited reimbursement rules, and low medical services, including dental services, especially in many low- and middle-income countries (LIC and MIC), limiting the development of this market dentistry in general [128].

The endodontics market was forecast to reach USD 1.56 billion in 2018; in 2020, it was estimated at USD 1.7 billion and to grow to USD 2.1 billion by 2026, with a CAGR of $4.1 \%$ [127], and previous forecasts indicated that the market would reach USD 1.61 billion by 2022, rising from USD 1.21 billion in 2016, with a CAGR of $5.1 \%$ in 2017 to 2022. The territorial structure of the growth of this market in this period is shown in Figure 3a, and the breakdown by end-users is shown in Figure 3b [129]. The global dental consumables market in 2016 reached USD 38.921 million, while it is forecasted that in 2023 it will reach USD 55.584 million, with a CAGR of 5.2\% from 2017 to 2023 [128]. To some extent, the global dental consumables market concerns endodontics (Figure 3c) in the field of obturators and permanent endodontic sealants, files divided in terms of material into steel and Ni-Ti alloy, and type into manual and rotary, as well as filling materials and sealants and general dental materials consumables, dental sealants, dental drills, patient bibs, aspirator tubes, saliva ejectors, and other auxiliary materials. 


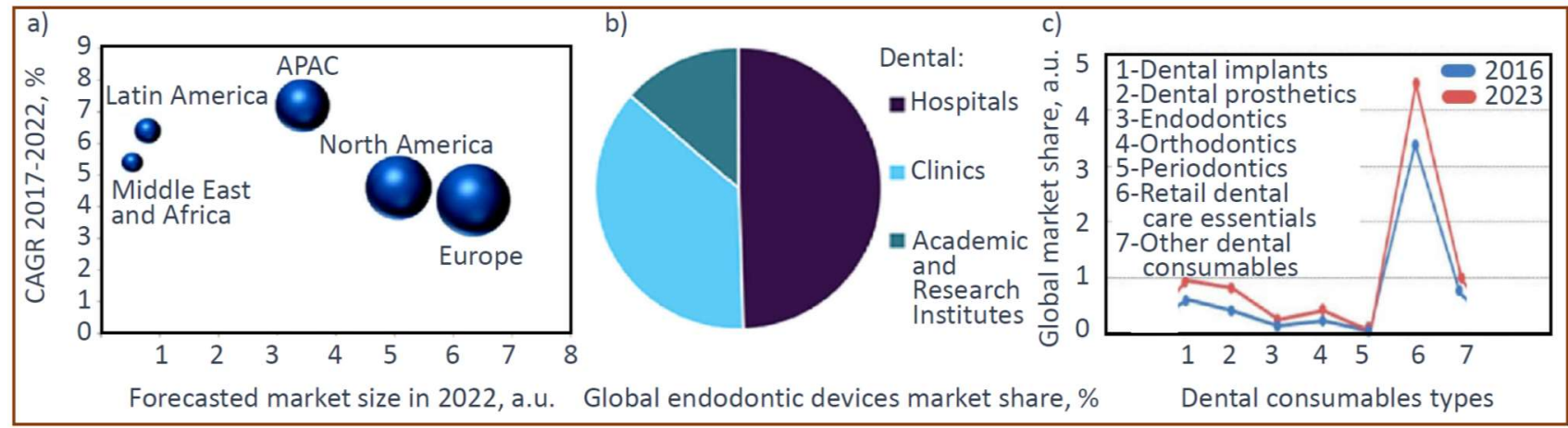

Figure 3. Forecasts for the growth of dental markets: (a) matrix of the forecasted size of the endodontics market (the diameter of the marker symbolizes the relative value) depending on the CAGR; (b) breakdown of the global endodontics market in 2018 by end-user; (c) an increase in the dental consumables market with the participation of endodontics in 2016-2023.

On the one hand, important elements of the global endodontic market, and most importantly, decisive for the effectiveness of endodontic treatments, are filling materials and the sealants used with them. For many years, the most commonly used and recognized material for filling root canals was gutta-percha [130-135]. The name gutta-percha refers to a stiff, naturally biologically inert, resilient, electrically nonconductive, thermoplastic latex made from the milk juice of certain plant species. The most important is the genus Palaquium from the Sapotaceae family, especially Palaquium gutta, as a tree growing in the Malay Peninsula and Indonesia, as well as Palaquium oblongifolia and Mimusops balata. However, it also occurs in Eucommia ulmoides, and in Europe in papillary and ordinary euonymus. In Australia, gutta-percha is a popular name used specifically for the euphorbia tree, Excoecaria parvifolia. The word gutta-percha comes from the name of the plant in Malay: "getah", which means "latex", while Percha or perca is the old name for the island of Sumatra. Gutta-percha is a natural polyterpene, a trans exclusively double-bonded polyisoprene polymer containing 1,4 polyisoprene, which forms a rubbery elastomer. The cis structure of polyisoprene is a typical latex elastomer. The polymer is sometimes referred to as gutta, and the name gutta-percha refers to a mixture of such a polymer with alcohol derivatives of triterpenes. While latex rubbers are amorphous with a molecular structure, the trans gutta-percha crystallizes, resulting in a more rigid material. Gutta-percha, which is less flexible than rubber, is characterized by greater chemical resistance, except for oxidizing acids, and it dissolves in aromatic and chlorinated hydrocarbons. It is not resistant to weather conditions, although it is ageing in the oxygen from the atmosphere. The product of these reactions is a brittle mass, which can be counteracted with appropriate additives. Gutta-percha is a good electrical insulator. The indigenous people of Malaysia used gutta-percha for many years, including on the handles of knives and walking sticks and for other purposes, until John Tradescant discovered it as the first European in 1656. William Montgomerie, a medical officer, was the first to use this material in 1842 for medical purposes, and even received a gold medal from the Royal Society of Arts in London in 1843 [136]. Since then, gutta-percha has been assessed as a useful practically natural thermoplastic and gained many practical and industrial uses in the second half of the 19th century. It was used as insulation for underwater telegraph cables and other electrical cables from 1851, which only changed with the invention of polyethene around 1940. It was also used to produce furniture and numerous kitchen utensils and, among others, golf balls, glues, gutta-percha paper, electroforming matrices, and stamps in the 19th century and first half of the 20th century.

Gutta-percha is a polymer that exists in three isomorphic forms: $\alpha, \beta$, and $\gamma$, with the $\alpha$ form being brittle at room temperature. Forms of gutta-percha $\alpha$ and $\beta$ go into the amorphous form and become liquid in the temperature range of $40-70^{\circ} \mathrm{C}$, while the melting point of the $\beta$ form is lower than the $\alpha$ forms. The $\alpha$ form is characteristic of 
gutta-percha produced by trees. Both forms contain trans bonds that differ in particle size. Gutta-percha density is $0.95-1.02 \mathrm{~g} / \mathrm{cm}^{3}$. In dentistry, only two isomorphic forms of gutta-percha are used- $\beta$, which exists in a solid state and changes into the $\alpha$ form of gutta-percha at temperatures of $48.6-55.7^{\circ} \mathrm{C}$; the melting point is $64^{\circ} \mathrm{C}$. Gutta-percha in the form of studs or pellets is used in endodontics. The pure form of $\beta$ gutta-percha is only $18-22 \%$, and the rest is a mixture of zinc oxide in the proportion of $59-75 \%$, barium and strontium sulphate in the proportion of $1.1-31.2 \%$, as well as other polymers and wax in the proportion of $1-4.1 \%$ [1]. The addition of zinc oxide improves plasticity and reduces brittleness, while barium sulphate provides X-ray impermeability so that it is possible to identify the filling using X-rays.

The physical and chemical properties of gutta-percha, including inter alia, indifference and biocompatibility, melting point, and ductility and plasticity, determined the usefulness of gutta-percha in endodontics. Thanks to thermoplasticity, polymeric materials with a gutta-percha matrix enable three-dimensional filling of the space inside the root canal. The use of gutta-percha each time requires the combined use of sealants based on synthetic resins, both in using cold and thermoplastic condensation methods. A gutta-percha matrix material together with the sealant used ensures a tight bond with the root canal wall. The tightness of filling the root canal with the filling material and its tight connection with the canal dentin are the main factors decided in the quality of endodontic treatment. The history of the use of thermally plasticized gutta-percha and sealer slightly exceeds half a century, since its first use by Herbert Schilder in 1967 [137-139]. However, this method of filling turned out to be too time-consuming and technically difficult to master, as this technique required the use of a heat-transfer device, which was heated several times over the burner until it was red, and inserted into the channel next to the gutta-percha point and then withdrawn to leave a plasticized material inside condensed apical with a plugger.

The cycle was repeated several times using several consecutive gutta-percha points and with the heating and condensation cycles repeated several times. The dentist's ability to perform vertical condensation using hot pluggers had significantly increased since the introduction in 1982 of the Touch's Heat Electric Heat Conveyor, which was activated when the tip was inserted into the root canal, eliminating the need for a torch and preventing frequent burns to the lips. The system introduced in 1987 by Stephen Buchanan provides a constant pressure to fill the irregular space of the canal with its side branches with warm gutta-percha and sealant, thanks to the continuous supply of heat for a sufficiently long time and the condensation of the gutta-percha with a constant vertical movement in the apical direction. Buchanan pluggers, available in four sizes, are designed so that their shape closely follows the shape of the developed channel and corresponds to the expansion of nonstandard main studs. Buchanan pluggers are made of stainless steel, and their plastic deformation allows deeper condensation, especially in narrow, bent channels. The Buchanan system enables temperature control up to $600^{\circ} \mathrm{C}$. Temperatures not higher than $350{ }^{\circ} \mathrm{C}$ do not cause irreversible damage to the periapical tissues, as confirmed clinically [137-139]. However, mild periodontitis associated with overheating may be short-lived but resolve no later than $12 \mathrm{~h}$. The Thermo-Hydraulic-Condensation [140-145] technique of filling root canals with the use of the Buchanan system, introduced 20 years ago, enables the lateral canals to be filled to a greater extent and consists of increasing the plasticity time of gutta-percha under the influence of temperature and pressure obtained during this procedure by using appropriate tooling (Figure 4) 


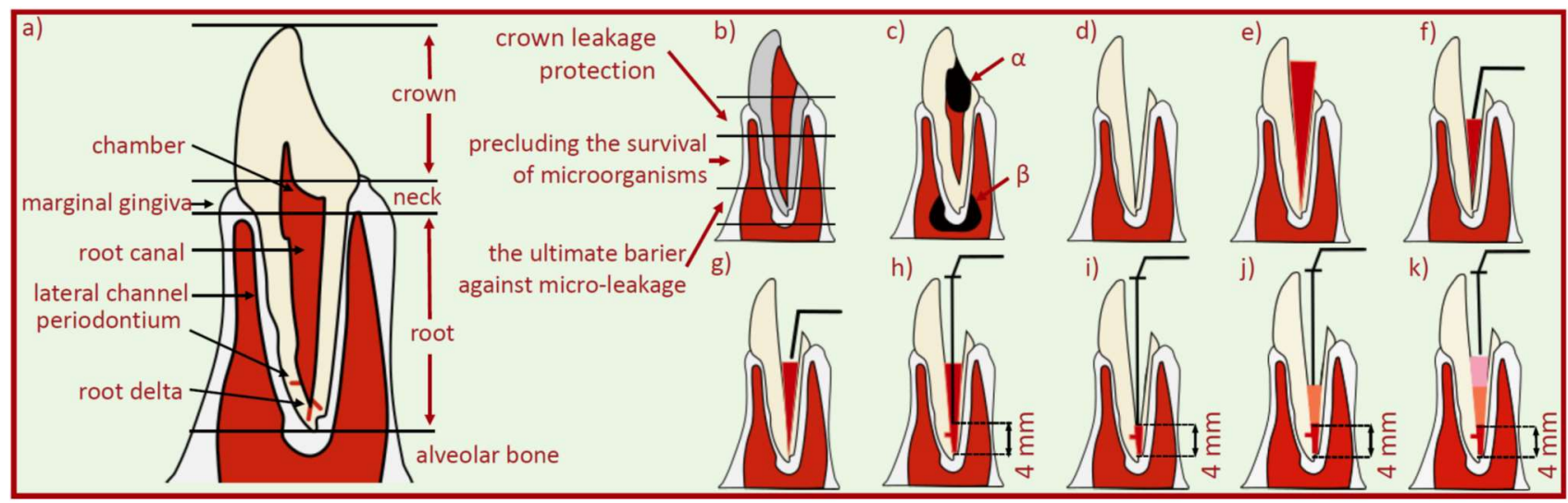

Figure 4. A diagram of a tooth cross-section showing: (a) the functions of the tooth pulp; (b) functions of filling the root canal; (c) dead pulp due to a carious lesion $(\alpha)$ with a periapical lesion $(\beta)$; $(\mathbf{d})$ evacuation of the ventricular-root pulp and conical preparation of the root canal; (e) fitting the main cone to the root canal; (f) cutting off the main stud with a heated plugger; (g) condensation at the mouth of the severed main cone with a cold Buchanan plugger; (h) plasticizing the main stud by introducing the heated plugger to a depth $4 \mathrm{~mm}$ less than the working length and cutting off the excess stud; (i) condensation of the plasticized main cone with a cold Buchanan plugger; (j) filling $1 / 3$ of the central part of the canal with liquid gutta-percha plasticized outside the canal and then condensing the material with a cold Buchanan plugger as in (i); (k) final filling of the canal with liquid gutta-percha plasticized outside the canal and then condensation of the material with a cold Buchanan plugger as in point (i).

Gutta-percha can also be used as a liquid for filling cold canals. For this purpose, capsules are available filled with gutta-percha powder with a particle size of less than 30 $\mu \mathrm{m}$ with the addition of anti-infective nanosilver particles and sealant particles.

Despite the numerous advantages of gutta-percha, documented by multiple clinical trials, which made it even considered the "gold standard" of endodontics, there were alarming signals that in some cases, it lacked proper bonding to dentin, which could suggest inadequacies in leakage prevention [146-155]. However, obturation errors of the dentist cannot be ruled out in such cases. Undoubtedly, the result of various assessments of the effectiveness of individual filler and sealing materials is determined by the methodology of these assessments, which has been pointed out in some publications [156,157]. There are also reports of difficulties in removing gutta-percha from the root canal, if necessary, with endodontic retreatment $[158,159]$. It can be counteracted by selecting nonstandard sealing materials [118,160-163] and attempts to use other filling materials, among the many given in Figure $2[164,165]$. Typically, this may improve some of the expected aspects of sealing previously reported, but it almost always worsens the removal of the filling material during subsequent endodontic treatment [166].

An alternative to gutta-percha is a synthetic thermoplastic filling material based on polyester materials, consisting of an organic part constituting a matrix of methacrylate resin and inorganic fillers, including bioactive glass and barium sulfate and X-ray impermeable oxychloride [167-173], first introduced in 2004 by Resilon Research, LLC, Madison, CT, USA [168]. Hence, this filler material is mainly known by the trade name Resilon, and the sealant has an eponymous name introduced by Sybron Dental Specialities, Orange, CA, USA, although it may also be presented as RealSeal from Pentron Clinical Technologies, Wallingford, CT, USA, or AH-26/AH-plus from Dentsply Maillefer (Ballaigues, Switzerland). Endorez (Ultradent Products, South Jordan, UT, USA), for example, has the ability to dissolve in some solvents such as chloroform, or to heat soften, which is of particular importance when endodontic retreatment is required, although gutta-percha can also be removed with a suitable solvent.

This system consists of three components, including [167,174,175]:

1. A self-etching primer comprising a sulfonic acid-terminated functional monomer, HEMA 2-hydroxyelylmethacrylate, water, and a polymerization initiator; 
2. A dual-curing resin sealant containing approximately $70 \%$ calcium hydroxide, bismuth oxychloride, barium glass, and silica filler;

3. A core made of synthetic thermoplastic filling material based on polyester materials, including approximately $65 \%$ of fillers with bismuth oxychloride, bioactive glass, and barium sulphate.

The core materials of this material, similarly to gutta-percha, are provided as studs and pellets, in ISO sizes in $0.02,0.04$ and 0.06 cones, and can be used as single studs or for use in the thermoplastic obturation method.

In the initial period of implementation, the filling material with a matrix of polyester materials showed leaks at the interface between the polyester-polymer material and the root canal walls much more often than gutta-percha. This was the result of, among other causes, polymerization contraction [131,132], and it was one of the reasons why many dentists refrained from using this material. Many more research results are available, focusing on identifying which of the two materials, gutta-percha or polyester matrix filling material, was more appropriate for endodontic treatment. Much less attention is paid to the remaining filling materials presented in Figure 2, which may indirectly indicate a real loss of their practical and clinical significance. Systematic research in many centres was prompted by good reports about the advantage of this new material over gutta-percha $[168,176,177]$ and the practical importance of the newly implemented sealants [178].

Moreover, it was pointed out that the characteristics of both materials are so similar that obturation techniques, including thermoplastic ones, commonly used concerning gutta-percha, can be easily transferred to this material [168]. It was reported that the bonding of this filling material with a matrix of polyester materials with dentine forms a monoblock [179-181], which would prove the dominance of this particular material. But opinions on this subject are not uniform, and in [182], it was even stated that this monoblock concept is not true. Statements have been presented in the literature that it is a material that legitimately competes with gutta-percha and even surpasses it; e.g., it has better adhesion to the surface of the prepared root canal $[183,184]$. Simultaneously, in the presence of chloroform, a distinct advantage is held by gutta-percha [185], and the opposite in the case of hydration or dampness of the root canal [186]. This view does not stand up to criticism, as many papers [118,187-189] indicate that gutta-percha has undoubtedly better adhesion, and it was very often concluded that both materials behave in the same way [190], even with the use of different sealants [181,191,192]. The result of these differences is the other sealing abilities of individual materials, which have been the subject of numerous studies [168,193]. Gutta-percha provides the best filling and tightness in the root canal, which is reported in a large number of papers [160,194-207], especially after longer periods [208,209], and even better antimicrobial protection than all other filling materials, especially filling materials with a matrix made of polyester materials. In the works [193,210-229], no differences were found in ensuring the tightness between gutta-percha and filling material with a matrix of polyester materials. However, in one of these studies, the advantage of the material with a polyester matrix was noticed in the apical zone of the root canal. In several studies [223,230,231], it was found out that the material with a matrix of polyester materials is not better than gutta-percha. Finally, in the works $[168,178,184,194,200,211,215,216,230,232-245]$, on the contrary, it is this material that provides the best tightness and reduces the number of gaps. It has also been more effective than mineral trioxide aggregate (MTA) $[246,247]$. The papers $[225,248]$ also indicated that it was not found that the technique of obturation, both cold and hot, was of any importance in ensuring tightness [249], which the authors of this article find to be highly controversial and not confirmed in their clinical practice. The effect of filling root canals with various materials on the fracture strength of endodontically treated teeth was also investigated. The obtained results are as ambiguous as in the previously discussed cases. It has been found that filling with gutta-percha improves these properties to the greatest extent $[250,251]$. However, in the works $[118,176,252-254]$, it is shown that it is the filling material with a matrix of polyester materials that provides better properties than gutta-percha. However, 
other studies $[255,256]$ indicated that these results did not differ, that there was no effect of changing the filler material [257], and that the matrix material made of polyester materials did not improve these properties [258].

A similar dispersion of opinions and assessments concerns the importance of material selection for cytotoxicity and possible postoperative complications related to it. Guttapercha provides better resistance to cytotoxic interactions $[259,260]$, although the opposite also is believed [261,262], as well as that the interactions of both materials are comparable [263-265]. Moreover, these fillings do not have antibacterial activity against many bacterial strains [266], or the effect is residual [267]. The research was also carried out on removing the filling if it was necessary to repeat the procedure [268-284], especially after some time. It turns out that in several studies, the lack of any differences was indicated [268,272], both with the use of hand tools [273-275] and rotary tools [269], although the advantage of gutta-percha with and without chloroform was also indicated [272-276], and when using other solvents, such as orange or eucalyptus oil [277], and when using tetrachlorethylene [278]. On the contrary, the advantages of the filling material with a matrix of polyester materials [279-282] were distinguished in this respect, also in the case of using chloroform $[268,279,280,283]$ and tools of the K3 type $[279,282]$. Thus, there are still some sceptical opinions as to the need to replace gutta-percha with another synthetic filling material based on polyester materials [284]. Many dentists still believe that this material cannot compete with gutta-percha, although many examples have shown that this may not be the case.

Nevertheless, such a significant dispersion of the results of the cited studies does not allow for a precise formulation of conclusions, especially since the commonly accepted mental abbreviation referring to the Hippocratic oath [285] dictates not to harm in the first place. These research results do not formulate a detailed and substantive, ethical view that gutta-percha should be replaced with another material, but it is no certainty that this is the truth. There is still insufficient clinical evidence to form a firm opinion in this regard, so further research is needed to determine the ranking of this filling material among all the others and, above all, its possible advantage over gutta-percha.

\section{General Concept and Scope of the Work Performed}

In the literature on the subject, we can find numerous reports on both clinical aspects of endodontic procedures performed by dentists, as well as publications focusing on the technical side, including the selection of materials, root canal preparation and obturation techniques, and the visualization results as given in Section 2 of this paper. Unfortunately, this last aspect is presented many times that to a small extent, and most often is not corresponding to the methodological and apparatus possibilities, which are currently at the disposal of materials science and engineering. It should be noted that, in essence, the materials and technology used in endodontics do not differ from other groups of materials, and the fact that dentists undertake such tests cannot constitute a sufficient, or actually any, justification in this matter. It should be stated, however, that works with a proper methodological level also appear. Therefore, regardless of the will and need to publish the substantive research results in this area, it was decided to present this paper on methodological issues in this area, which may be useful to subsequent authors who prepare their publications in this area.

Therefore, this paper presents a detailed methodological approach to objectivity in the assessment of endodontic treatment through in vitro studies, including a comparative analysis on the example of human incisors of the maxilla, canines, and single-canal premolars of the maxilla and mandible, removed from various patients for orthodontic, prosthetic, and periodontal indications, while respecting all ethical principles and under the supervision of the territorially competent Bioethics Committee.

The tasks presented in this paper were focused mainly on the development of research methodology. In a series of other publications [286], the detailed results of these studies in which the methodology received less attention are presented. In this paper, however, only 
some symptomatic research results confirmed the adopted methodological approach. In this sense, this paper is the first in a series of research results presented in this way. The analysed methodological aspects included selection of:

1. Root canal filling material during endodontic treatment, assuming that the process can be carried out both cold and warm;

2. The methodology of root canal preparation with the use of available methods and various tools to ensure three-dimensional hermetization of the root canal with replacement material;

3. Root canal obturation technology during cold and hot endodontic treatment;

4. The most advantageous visualization methods for assessing the effectiveness of endodontic treatment, including the use of methodological experiences used in materials science and engineering for the study of micro- and nanostructured objects.

To analyse these aspects, it is possible to use several basic methods of organization and management: literature review; source data analysis; issue mapping; Social, Technological, Economical, Environmental, and Political (STEEP) analysis; Strengths, Weaknesses, Opportunities, and Threats (SWOT) analysis; and auxiliary methods including benchmarking, multicriteria analysis, and statistical methods. In this paper, several of these methods were used to increase the knowledge of endodontic treatment and ensure greater clinical success. For the selection of the filling material and the most beneficial developing and obturation methods of the root canal due to the patient's health conditions, and to develop a methodology for assessing the tightness of root canal filling, with a resolving power comparable to that required in material engineering for the study of micro- or nanostructured objects, a detailed multipoint research methodology was planned, including several subsequent activities:

1. Performing a literature review and preliminary analyses to determine the scope of materials, techniques for the development and obturation of root canals, and the selection of methods for assessing the effectiveness of the filling, which will be subjected to detailed tests, with the results presented in subsequent publications in this series [286];

2. Performing a theoretical analysis using the methods of procedural benchmarking and comparative analysis, with the use of contextual matrices to optimize the selection of materials virtually, techniques for the development and obturation of root canals, methods for assessing the effectiveness of fillings, which methods are usually used among others in management science and especially in foresight research as part of knowledge management; the results of the analyses are the subject of this paper;

3. Performing a series of in vitro tests on the removed human incisors of the maxilla, canines, and single-canal premolars of the maxilla and mandible for empirical confirmation of the correctness of the methodology selected in the virtual analysis mode presented in this paper, and substantive studies of the regularities presented in the series of subsequent publications [286];

4. Development of teeth for testing with the use of rotary nickel-titanium conical drills, and comparatively, nickel-titanium hand-held drills;

5. Obturation with filling material selected in the virtual analysis mode, with the use of contextual matrices and comparative material based on polymeric polyester materials: Resilon, of the trade name RealSeal, with the use of cold and hot techniques;

6. Demineralization of parts of the prepared and filled teeth with the use of various analysed methods to prepare them for microscopic examinations;

7. Making longitudinal fractures in the parts of the prepared and filled tooth roots, after cutting the notches along the axis of the teeth, cooling them in liquid nitrogen, and making longitudinal fractures in these conditions initiated by the incisions made;

8. Performing materialographic examinations on the transverse and longitudinal sections of the prepared and filled tooth roots;

9. Performing microscopic examinations of exams, fractures, and demineralized teeth with the use of a stereoscopic light microscope, scanning electron microscope, and 
confocal laser microscope to verify experimentally the developed methodology of material selection, techniques for the development and obturation of root canals, methods for assessing the effectiveness of fillings, and substantive tests of regularities presented in a series of subsequent publications [286];

10. Development of methodological procedures for the selection of materials, development and obturation techniques of root canals, assessing methods of the filling effectiveness, and the substantive results of the examination of the regularities, together with the examinations of statistical results, presented in a series of subsequent publications [286].

The implementation of the research tasks assigned in this way enables the achievement of the following basic goals:

1. Selecting the conditions for the preparation and obstruction of the root canals to ensure that the filling remains in the oral cavity of the endodontically treated teeth for the longest possible time;

2. Selecting the optimal methods for the preparation and obturation of root canals, ensuring the best tightness of the filling;

3. Development of the most appropriate and useful research methods to assess the effectiveness of endodontic treatment due to the appropriate quality of root canal fillings and the required high tightness, possibly with the minimum number of the smallest gaps on the border of the root canal wall and the filling material;

4. Explanation of the reasons for the differences in the tightness of the filling between the root canal wall and the filling material in connection with the considered methods of root canal preparation and obturation;

5. In line with the previously presented assumptions, this paper covers the first three of the presented research tasks, while the fourth task is the main content of subsequent papers from the announced series [286].

\section{Description of the Methodological Concept of Materials Selection, Techniques for the Development and Obturation of Root Canals, and the Assessment of the Effectiveness of Fillings}

The assumptions of the so-called "digital twins" as an approach characteristic of Industry $4.0[64,65,67-98]$ and the resulting idea of Dentistry $4.0[62,63,66]$ were adopted to achieve the set research goals. The concept of the "digital twin" allows many experiments to be carried out in a virtual space before the analysed product or object is physically created or made available for research, even without its physical existence. Experimental verification of the solution or variant selected virtually as the most advantageous is sufficient due to considered criteria.

Therefore, appropriate laboratory tests were preceded by a theoretical analysis with methods usually used, among others, in the science of management, especially in foresight research as part of knowledge management, which also includes procedural benchmarking and comparative analysis with the use of contextual matrices. To solve the issues constituting the essence of this paper, the methodology and research results, developed and published in own works on surface engineering technologies [69,287-304], were appropriately adapted.

Each time the issues subject to research using knowledge engineering must be considered while taking into account the background, which is the closer and further environment, it is best to use integrated methods of strategic analysis. A SWOT analysis can be directly implemented to characterize and assess the intensity of the impact of positive and negative external factors, called opportunities and threats, respectively, additionally taking into account internal factors: positive (strengths) and negative (weaknesses) (Figure 5). 


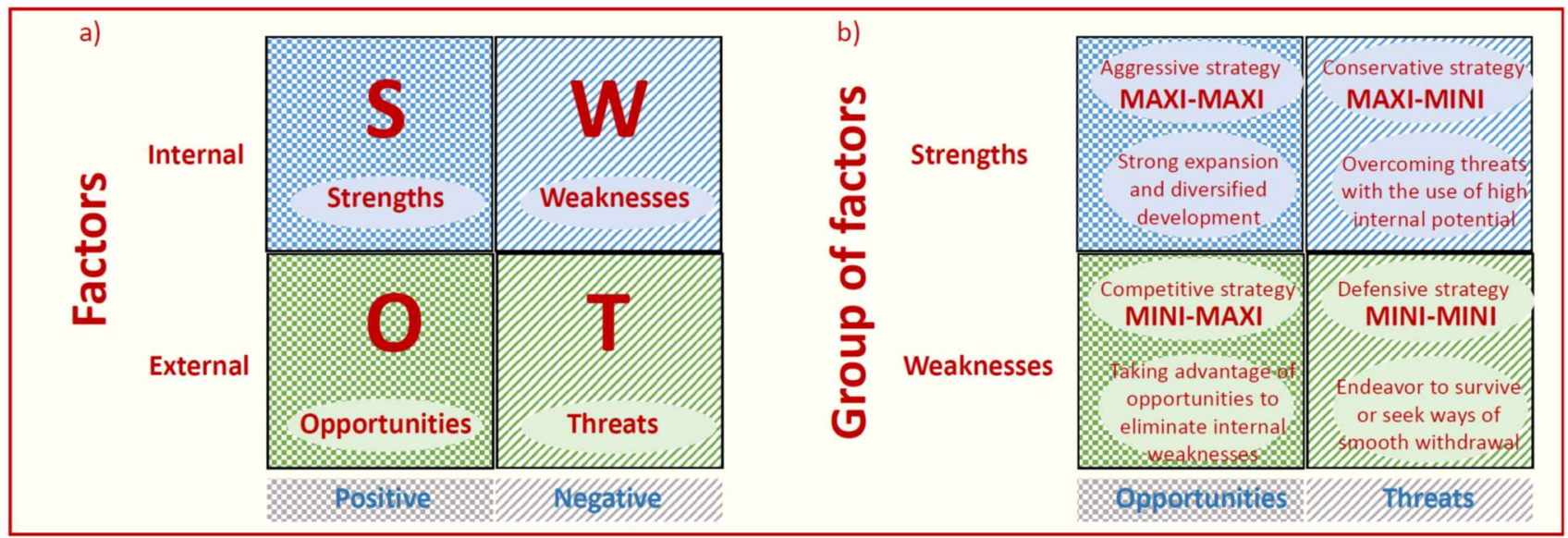

Figure 5. Scheme of the SWOT (strengths-weaknesses-opportunities-threats) analysis: (a) the considered factor groups; (b) the recommended strategies of activity concerning the analysed groups of technologies.

Multicriteria analysis can be used by defining technology assessment criteria to quantify the strengths and weaknesses of technologies, as well as opportunities and threats to them from the environment and assigning them, to sum up, weights reflecting their importance, and then assessing individual technologies according to previously adopted criteria in a specific scale. The Universal Relative State Scale (Figure 6) can be used; it is a 10-point unipolar positive interval scale without zero, where 1 is the minimum and 10 is the maximum possible score.

\begin{tabular}{|c|c|c|c|}
\hline Numerical value & Class discriminant & Level & perfection \\
\hline 10 & $0.95 \longleftarrow$ & Excellent & \\
\hline 9 & 0.85 & Very high & \\
\hline 8 & 0.75 & High & normally \\
\hline 7 & 0.65 & Quite high & \\
\hline 6 & $0.55 \leftarrow$ & Moderate & \\
\hline 5 & 0.45 & Medium & \\
\hline 4 & $-0.35 \leftarrow$ & Quite low & mediocrity \\
\hline 3 & 0.25 & Low & \\
\hline 2 & 0.15 & Very low & \\
\hline 1 & 0.05 & Minimal & \\
\hline
\end{tabular}

Figure 6. The Universal Relative State Scale.

The numerical rating of the technology awarded under each of the criteria should be multiplied by its weight. Then the individual partial results are summed up, thus obtaining a weighted average that is a tool for comparative analysis, allowing us to determine the significance of a given technology against others that also were analysed. When applying multicriteria analysis of each technology, four ratings should be given, expressing numerically its strengths, weaknesses, opportunities, and threats arising from the environment. Depending on the predominance of strengths or weaknesses and opportunities or threats, each analysed group of technologies can be assigned one of four general strategies of conduct (Figure 5b). It uses such a selected methodological apparatus, allowing for a comparative analysis of technology, defining critical technologies understood as priority technologies with the best development prospects and/or key importance in the industry. 
The basis for actions taken in this mode is expert knowledge; i.e., generally including the life and professional experience of experts. This assessment can be objectified by consulting a large group of experts, although the view can be obtained even after using the knowledge of one expert who is close to the issues assessed. It is about transforming inherently difficult to measure, tacit expert knowledge into explicit knowledge, available to the environment and possible to describe in the form of, e.g., a publication or a feasible procedure (Figure 7a), with the use of qualitative, semiquantitative and quantitative methods dedicated to this task. In the undertaken activities, the benchmarking method is helpful; it is based on comparing the situation of the assessed entity to the leader, on using to solve problems of a similar type, and proven and effective solutions successfully applied in other areas. The approach presented in this paper uses research methods from a completely different subject area. The material engineering research apparatus and the achievements of technological foresight of surface engineering were used to assess the quality and tightness of root canal fillings. An approach from the area of concurrent engineering was also used, the essence of which boils down to the methodology of solving important tasks, in this case concerning the methodology of endodontic treatment, by a sufficiently large group of participants, as a result of combining activities and knowledge and the obtained synergistic effect (Figure $7 b$ ).

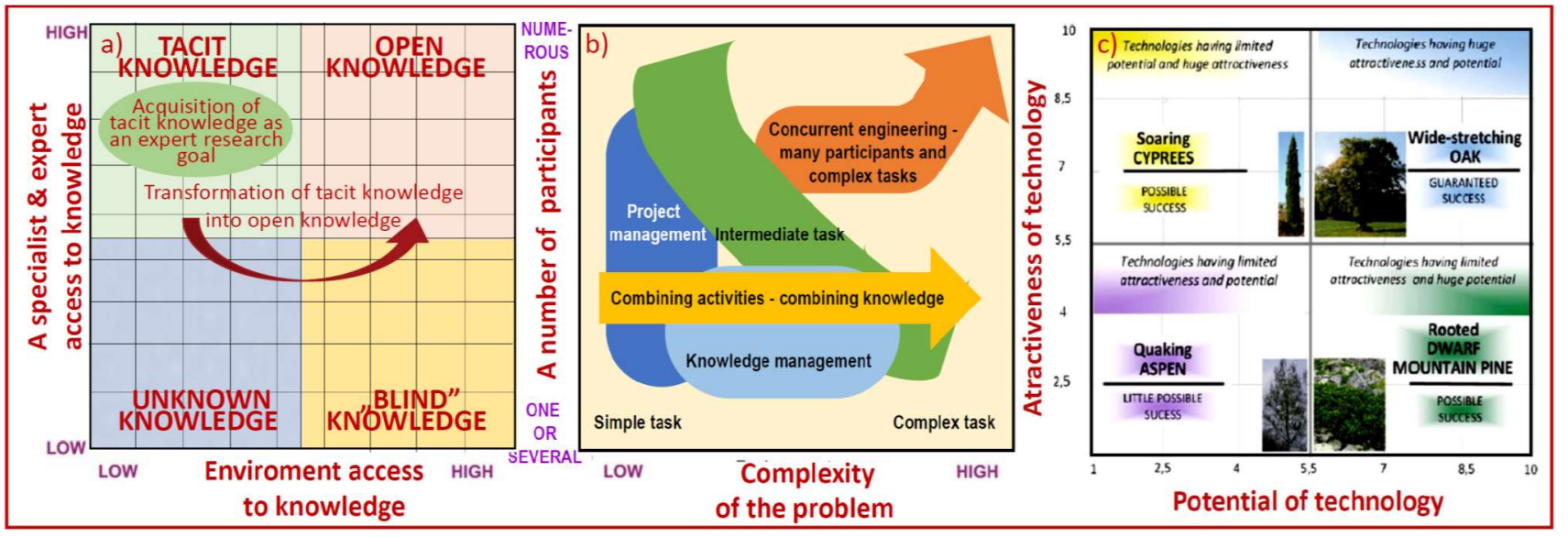

Figure 7. Schemes of context matrices: (a) knowledge availability; (b) dependence of the complexity of the problem to be solved on the number of participants in concurrent engineering; (c) dendrological value of technology-presentation of the approach.

Positioning of the method or procedure among those covered by the analysis and their usefulness in endodontological treatment is achieved by a set of contextual matrices, containing in particular matrices analogous to dendrological technology value matrices, adopted in the foresight analysis of surface engineering technology, where individual technologies were positioned depending on their potential and attractiveness, using original dendrological matrices (Figure 7c). These matrices are tools for comparative graphical analysis of particular methods and materials or their groups. The dendrological matrix of technology values graphically presents the assessment of individual groups of technologies in terms of their potentials, which is the real objective value of a given technology and attractiveness, reflecting the subjective perception of a given technology among its potential users.

The potential of a given group of technologies, expressed with the use of the previously described 10-degree universal scale of relative states, plotted on the horizontal axis of the dendrological matrix, is the result of a multicriteria analysis carried out based on expert assessment, taking into account in appropriate proportions the creative, application, qualitative, developmental, and technical potential expressed by an appropriately selected set of criteria that were assigned appropriate weights. On the vertical axis of the dendrological matrix, the level of attractiveness of a given group of technologies was plotted, being 
a weighted average of expert assessment made based on detailed criteria corresponding to economic, ecological, humanistic, natural and systemic attractiveness. Depending on the value of the potential and the level of attractiveness, which were determined as part of the expert assessment, each of the analysed technologies or, more generally, objects were placed in one of the matrix quarters, which were distinguished in the dendrological matrix of the value of technologies or other analysed objects. This approach has already been generalized and used to analyse many problems related to, among others, materials engineering, surface engineering, and technology of material processes, included in our own published works $[1,64,69,132,287-314]$ and in the works of other authors [315-328].

Depending on the location of the analysed aspect, product, or object in a given quarter, one can conclude about its successes, respectively market or methodological, as in the discussed case concerning endodontics. Because of the generalization of the method, in this case, to the issues of endodontics, the concepts of potential and attractiveness should also be treated as generalized, and can be selected in each specific case according to actual needs.

The quarter of wide-stretching oak includes technologies or aspects characterised by the high potential in the range $(5.5 ; 10)$ and high attractiveness $(5.5 ; 10)$, reflecting the best possible situation for future success and expansion; e.g., market. The analysed case is, of course, a comparative analysis of the aspects characterizing individual methods and materials used in endodontics.

The quarter of the soaring cypress tree includes technologies or, more generally, objects with limited potential in the range $(1 ; 5.5)$, but with high attractiveness in the range $(5.5 ; 10)$, which makes these technologies possible. However, care should be taken that the apparent advantages of such an object or aspect do not obscure the actual application possibilities.

The next quarter of rooted dwarf mountain pine includes technologies and, more generally, objects of limited attractiveness in the range $(1 ; 5.5)$, but with high potential in the range $(5.5 ; 10)$, making their future success highly probable. However, it would require a lot of additional activity to improve the practical applicability of such locations.

The quarter of quaking aspen, on the other hand, contains the weakest technologies or objects on limited potential in the range $(1 ; 5.5)$ and of limited attractiveness in the range $(1 ; 5.5)$, whose future success is unlikely or impossible in such a situation; very often it is necessary to refrain from engaging in activities aimed at the practical application of such a solution.

The inspiration for developing methodological assumptions during the creation of the dendrological matrix was the portfolio methods commonly known in management sciences, serving to characterize the company's product portfolio. The methodological construction of dendrological matrices and all other portfolio matrices allows for a graphic presentation of the comparative analysis carried out, with results based on two criteria/factors placed on the horizontal (x) and vertical (y) axis of the matrix, respectively. The most famous matrix of this type was developed by the Boston Consulting Group (BCG) [329] (Figure 8a). BCG matrices owe their extraordinary popularity to their appeal to simple associations and intuitive inference. In management sciences, associations with the star as the dominant market entity and cash cow are well known, and the dog is a symbol of a failed offer while a question mark does not bode well for a given project but does not exclude it. 

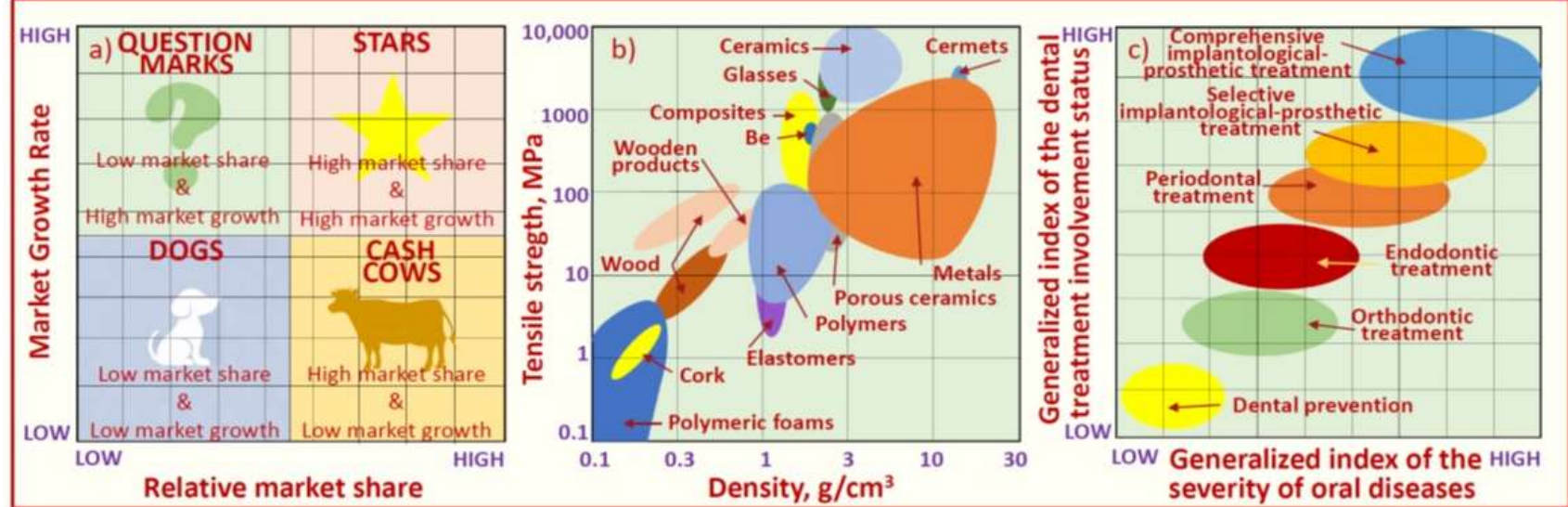

Figure 8. Contextual matrix schemas: (a) BCG for market assessment; (b) properties of various groups of engineering materials, the so-called "Maps of M.F. Ashby"; (c) an original concept of the matrix of advancement and treatment of oral diseases.

Even though the methodological assumptions are analogous to the previous one, such a matrix concerning the technology was called the meteorological matrix of environmental impact, concerning the graphical analysis of the influence of external factors on particular groups of technologies, or other aspects, respectively. The group of such matrices also includes the so-called "Maps of M.F. Ashby". However, their structure consists of two groups of properties of engineering materials; for example, as presented in Figure 8b. Similarly, it is possible to analyse directly the difficulties affecting negatively and opportunities positively influencing the analysed aspects in dentistry. Figure $8 \mathrm{c}$ schematically presents the authors' general concept of the matrix of advancement and treatment of oral diseases. In the following chapters, the authors' quantitative assessments of the impact of various factors on the effects of endodontic treatment are presented.

In the case analysed in this paper, appropriate, proprietary contextual matrices for endodontics were developed, containing strategic positions of individual methods resulting from this work. The axes are equipped with descriptors other than in the case of the surface engineering technology analysis, adequate for the analysed problem of selecting the appropriate root canal filling material, selecting the optimal method of developing and filling the root canal, and an effective method of assessing the tightness of the root canal filling, guaranteeing the effectiveness of endodontic treatment. To select the descriptors listed for research, we determined their generalized attractiveness for them and used the technique of procedural benchmarking, using the weighted scoring method for the analysis of preferences and the universal scale of relative states. The ranking and scoring methods were used to analyse tendencies, and general attractiveness in the analysed contexts was adopted as the basic criterion. This procedure was used to decide what research issues should be dealt with using the literature knowledge. First, the materials that best performed their functions when used for filling root canals were identified. Their attractiveness was analysed in terms of mechanical strength influencing a potential root fracture and the quality of the filling performed in the root canal. Next, using the effect of the first analysis, an analysis of obstruction techniques used in root canal treatment with the use of previously selected materials was carried out. The usefulness of these techniques was analysed in terms of the technique's effectiveness and the resistance of the used material to tooth root fracture. This feature is of key importance in determining the durability of the applied filling and, consequently, the effectiveness of the entire treatment. The analysis of the assessment results of obturation techniques allowed the third analysis to be carried out, which determined which techniques of root canal filling with previously selected materials and obturation techniques would meet the patient's requirements. The attractiveness of root canal filling methods was checked in terms of the quality of the performed filling and organizational aspects, including the overall cost of applying the 
technique and the difficulty of mastering the technique by the operator. The last analysis concerned the method selection for assessing the tightness of root canal fillings, which would be best for the analysed materials combined with organic material. The methods used on a large scale in studies dealing with the topic of tightness of root canal fillings were analysed, and methods used in other fields of knowledge could be implemented for use in this case. All the results of these analyses have been included in this paper and an exemplary description of the obtained test results. The detailed test results will be included in subsequent papers from the announced series.

The generalized attractiveness was determined for comparative evaluation, aimed at qualifying the importance of individual features in the relationship between them, using the weighted scoring method. The principle of relativization of evaluation criteria was applied, assuming differences in the significance of the criteria used, and the principle of admissibility. It used a specific group of admissibility conditions, constituting a selection filter that positively or negatively qualified a given object. The weighted scoring method allowed for the multicriteria aggregate assessment using a range scale. Detailed evaluation criteria were adopted, and their gradation was introduced. The specific weights to individual criteria were assigned based on the literature analysis on the considered criteria, interviews with dentists, and our own experience gained during dental practice. Then, the weighted values for the individual criteria were calculated. The values that were the basis for the comparative analysis were summed up to obtain finally. Table 1 presents the types of proprietary endodontic contextual matrices developed and presented in this paper.

Table 1. Types of contextual matrices related to endodontics presented in the paper.

\begin{tabular}{|c|c|c|c|c|c|}
\hline No. & Table & Figure & $\begin{array}{l}\text { Analysed Dependence on the } \\
\text { Context Matrix }\end{array}$ & $\begin{array}{l}\text { Quantity on the Horizontal } \\
\text { Axis (Generalized Potential) }\end{array}$ & $\begin{array}{l}\text { Quantity on the Vertical Axis } \\
\text { (Generalized Attractiveness) }\end{array}$ \\
\hline 1. & Table 2 & Figure 4 & Materials selection & & $\begin{array}{l}\text { Generalized index of material } \\
\text { strength in the root canal }\end{array}$ \\
\hline 2. & Table 3 & Figure & $\begin{array}{l}\text { Root canal development } \\
\text { technique selection }\end{array}$ & $\begin{array}{l}\text { Generalized organizational } \\
\text { index of techniques for the } \\
\text { development of root canals }\end{array}$ & $\begin{array}{l}\text { Generalized index of the } \\
\text { quality of filling with selected } \\
\text { techniques }\end{array}$ \\
\hline 3. & Table 4 & Figure 7 & Techniques of obturation selection & $\begin{array}{c}\text { Generalized index of material } \\
\text { strength applied in root canal } \\
\text { obturation techniques }\end{array}$ & $\begin{array}{l}\text { Generalized index of the } \\
\text { effectiveness of root canal } \\
\text { obturation techniques }\end{array}$ \\
\hline 4. & Table 5 & Figure 8 & $\begin{array}{l}\text { Assessing the tightness of root } \\
\text { canal filling selection }\end{array}$ & $\begin{array}{l}\text { Generalized index of } \\
\text { organizational conditions }\end{array}$ & $\begin{array}{l}\text { Generalized index of } \\
\text { investigations effectiveness }\end{array}$ \\
\hline
\end{tabular}

\section{Description of Authors' Contextual Matrices Concerning Materials for Filling Root Canals}

The seven most common materials used to fill root canals for obturation were analysed. The suitability of individual materials depended on the material strength index in the root canal and the material quality index. To determine the strength index of the material in the root canal, we assessed to what extent the assessed material in the root canal strengthens the tooth root after time so that it maintains mechanical resistance to fracture in combination with keeping the tightness of the filling by minimizing resorption of the filling over time. The material quality index in the root canal was determined by analysing the features of individual materials according to the criteria proposed by Grossman [330]. The impact of the introduced material on the patient's body; the possibility of eliminating bacteria from the filled root canal also through the possibility of sterilization, increasing the asepsis of the treatment and minimizing the risk of reintroducing bacteria into the treatment area; the ease with which the material can be removed in the event of retreatment, as well as the possibility of correct X-ray diagnostics and control were assessed. Table 2 lists all the analysed materials used to fill the root canals and specifies the criteria of mechanical strength influencing a potential root fracture and the quality of the root canal filling. 
Table 2. The set of criteria adopted for the virtual contextual analysis regarding the selection of the material filling the root canal during endodontic treatment.

\begin{tabular}{|c|c|c|c|c|c|c|c|c|c|}
\hline \multicolumn{3}{|c|}{ General Descriptors } & \multirow{2}{*}{\multicolumn{5}{|c|}{$\begin{array}{l}\text { Criteria for Determining the } \\
\text { Generalized Quality Index of the } \\
\text { Root Canal Filling Material }\end{array}$}} & \multirow{2}{*}{\multicolumn{2}{|c|}{$\begin{array}{l}\text { Criteria for } \\
\text { Determining the } \\
\text { Generalized Strength } \\
\text { Index of the Root } \\
\text { Canal Filling Materia }\end{array}$}} \\
\hline Material & $\begin{array}{c}\text { Application } \\
\text { Form/Consistency }\end{array}$ & $\begin{array}{l}\text { Method of } \\
\text { Application to the } \\
\text { Root Canal }\end{array}$ & & & & & & & \\
\hline $\begin{array}{c}\text { Based on } \\
\text { gutta-percha } \\
\text { Based on } \\
\text { polyesters } \\
\text { silver studs } \\
\text { Based on synthetic } \\
\text { resins } \\
\text { Based on zinc } \\
\text { oxide with eugenol } \\
\text { Based on silicones } \\
\text { Based on calcium } \\
\text { hydroxide } \\
\text { glass ionomer } \\
\text { cements }\end{array}$ & Pellets & $\begin{array}{l}\text { Independently } \\
\text { On the Lentulo } \\
\text { needle } \\
\text { As a sealant for } \\
\text { studs } \\
\text { As a gutta-percha } \\
\text { sealant }\end{array}$ & 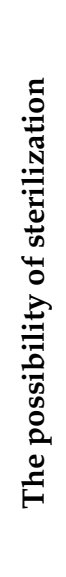 & 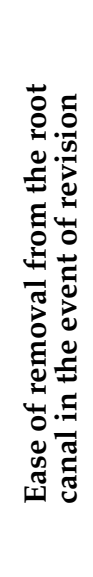 & 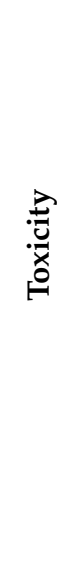 & 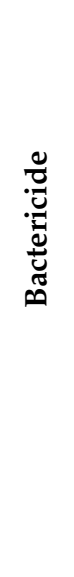 & 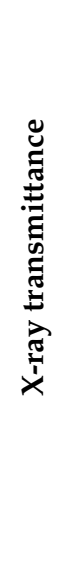 & 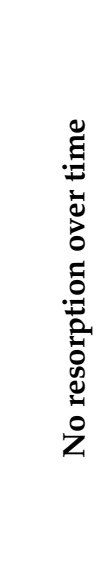 & 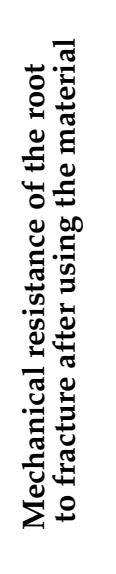 \\
\hline & Weight & & 0.1 & 0.25 & 0.4 & 0.2 & 0.05 & 0.4 & 0.6 \\
\hline
\end{tabular}

The performed analysis allowed for the elimination of three materials from further considerations, which stood out after the analysis, without achieving minimal results in terms of the normality of relative states. Silver studs and materials based on zinc oxide and eugenol achieved both quality and strength indexes that were below average, while materials based on calcium hydroxide achieved a quality index at a high level; however, when compared to the index of material strength in the root canal, the overall result turned out to be unsatisfactory because, despite the fulfilment of the Grossman criterion, it was not certain whether the analysed material would be able to preserve the patient's tooth several years after the treatment. The remaining four obturation methods achieved high results in the strength index of materials in the root canal. Still, none of them reached the filling quality index at the level of normality. The analysis results showed that none of the materials selected for evaluation was flawless. Still, it was possible to decide which materials stood out from the others unequivocally. Those were selected for further research, the detailed results of which are presented in the announced series. Thus, the analysis of the results made it possible to select two materials for further research: a filling material based on gutta-percha and a material based on polymeric polyester materials. The first one achieved an excellent result in terms of strength and a relatively high level of filling quality. On the other hand, the second material had a worse strength score but a relatively high-quality index. Figure 9 shows the attractiveness matrix of materials used to fill root canals, including the results of the analyses performed and described above. 


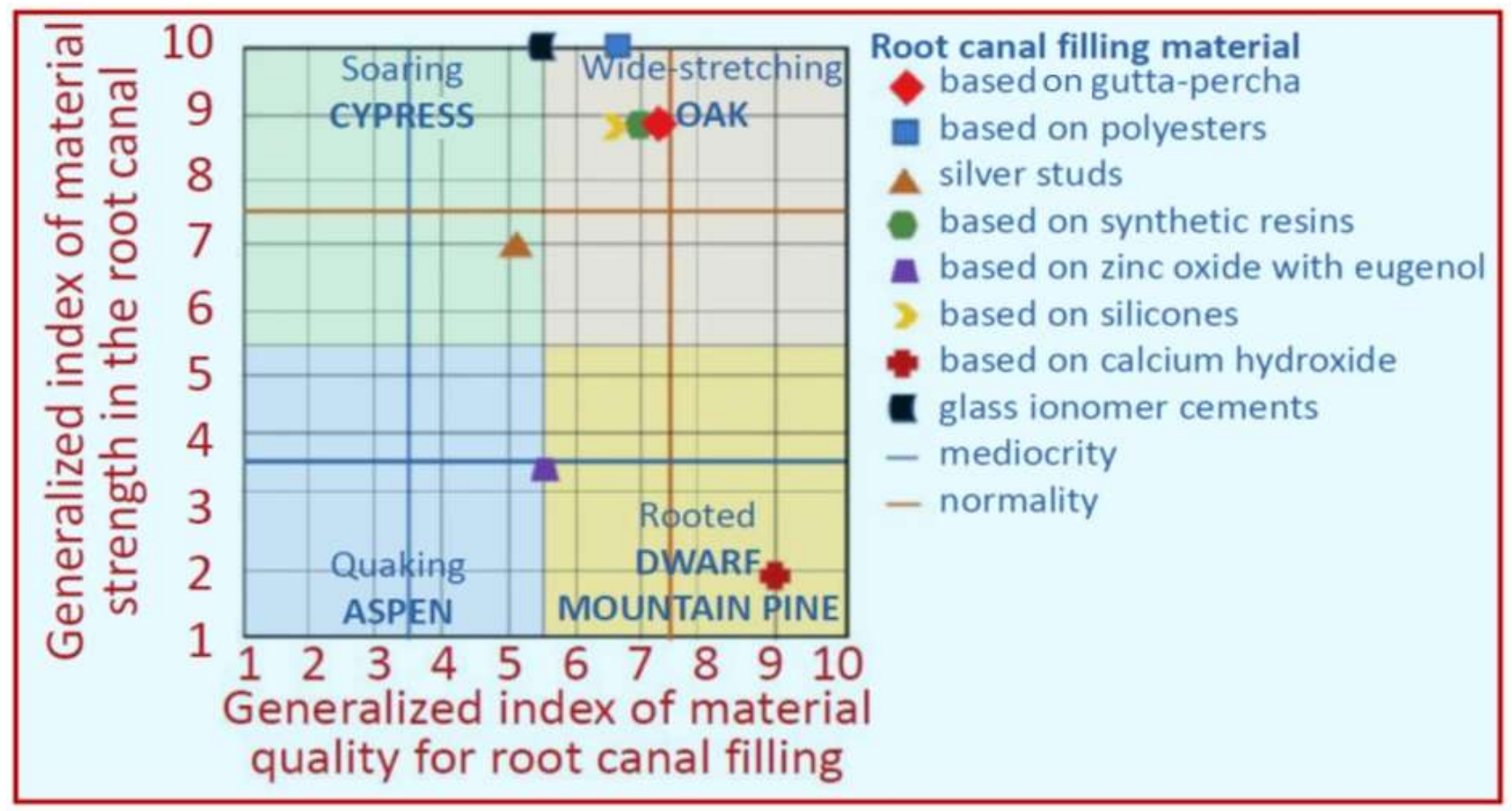

Figure 9. Contextual matrix of the attractiveness of materials used to fill root canals.

\section{Description of Authors' Contextual Matrices Relating to Techniques for the Development of Root Canals}

For an endodontic treatment to proceed without complications, it is extremely important to select the root canal preparation technique correctly. Therefore, all three currently used techniques of development were analysed: laser techniques, ultrasound techniques, and commonly used mechanical techniques, including the material from which the tools are manufactured. The usefulness of unique techniques for the development of the root canal and the material of the tools was dependent on the quality indicator of the performed root canal preparation. In this context, the feasibility of conical preparation and the potential for errors during the procedure, such as pushing the cut dentin beyond the periapical opening and the loss of the natural course of the canal results in the formation of niches, were assessed. Another extremely important element is the minimization of the risk of breaking the tool in the canal. Hence, the highest importance was given to this feature. The possibility of disinfecting the root canal and the risk of thermal damage to the tooth tissues were also assessed. These have a major impact on the time the treated tooth can remain in the mouth without complications, such as bacterial growth and bone changes. The second aspect in which the techniques for the development of root canals have been analysed were organizational conditions, which include the unit cost of the procedure, which should be understood as the cost of purchasing equipment, replaceable tips, materials used in a given technique, and the duration of the procedure. These factors affect the costs of the procedure and the difficulty of mastering a given technique by the dentist, taking into account access to specialist training, the duration and costs of training, and the period in which the operator will be fully operational. Table 3 summarizes all the described techniques for the development of root canals and specifies the quality criteria for developing root canals and the related organizational conditions. 
Table 3. The set of criteria adopted for the virtual contextual analysis concerning the selection of techniques for the development of root canals in endodontic treatment.

\begin{tabular}{|c|c|c|}
\hline $\begin{array}{l}\text { General } \\
\text { Descriptors-Techniques } \\
\text { for the Development of } \\
\text { Root Canals }\end{array}$ & $\begin{array}{c}\text { Criteria for Determining the Generalized Quality } \\
\text { Index of the Root Canal Filling with Selected } \\
\text { Techniques }\end{array}$ & $\begin{array}{c}\text { Criteria for Determining the } \\
\text { Generalized Organizational Index of } \\
\text { Techniques for the Development of } \\
\text { Root Canals }\end{array}$ \\
\hline
\end{tabular}

Laser

Ultrasonic

Mechanical-nickeltitanium tools

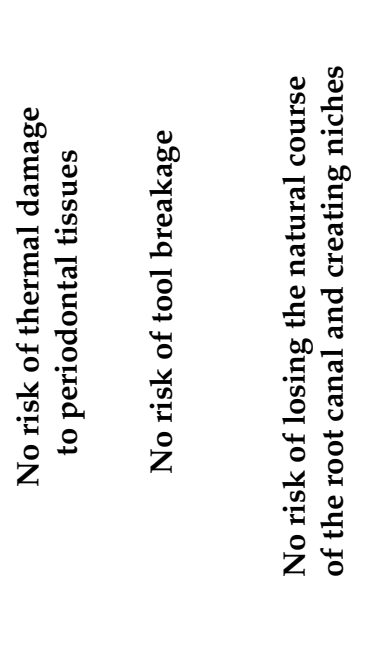

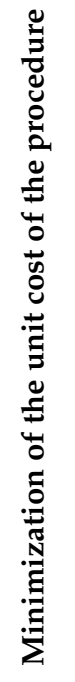

\section{Weight}

0.2

0.1

0.1

0.2

0.1

0.5

0.5

The analysis made it possible to eliminate two techniques of root canal development from detailed studies i.e., the laser technique and the ultrasound technique. The laser processing technique achieved an average result in terms of the quality of the prepared study. The value of the indicator of organizational conditions was disqualified because it is an extremely expensive and complicated method, and the expenditure incurred does not translate into measurable benefits from its use. Therefore, it was rejected as nondevelopmental. The technique of root canal preparation using ultrasound also achieved unsatisfactory results in the attractiveness analysis. This technique was extremely average in terms of the quality of the studies performed and disqualifying in terms of organizational conditions. The costs of its use, similar to laser technology, are very high, and the quality of the study was not higher than with mechanical methods. Therefore, the analysis results allowed the choice of mechanical methods, as they have just achieved the best results due to the analysis carried out.

It should be noted, however, that mechanical methods are not without weaknesses. Their effective use also requires experience, and the risk of complications is also high. However, the cost of their use is relatively low due to the universality of their application, and the access to training materials and courses is wide, which makes it easier for the operator to acquire skills allowing for their wide application in a relatively short time. A better-quality index characterized the method using steel tools, but a lower index of organizational conditions than the technique using nickel-titanium tools. The selection between these two methods depends on the specific case and operator preference. As the results of the analyses show, there is a need to find a method of developing a breakthrough method of developing root canals that will meet the requirements of dentists to a greater extent than the ones used so far, and even more important requirements resulting from the actual needs of patients. Figure 10 shows the attractiveness matrix for techniques for the development of root canals. 


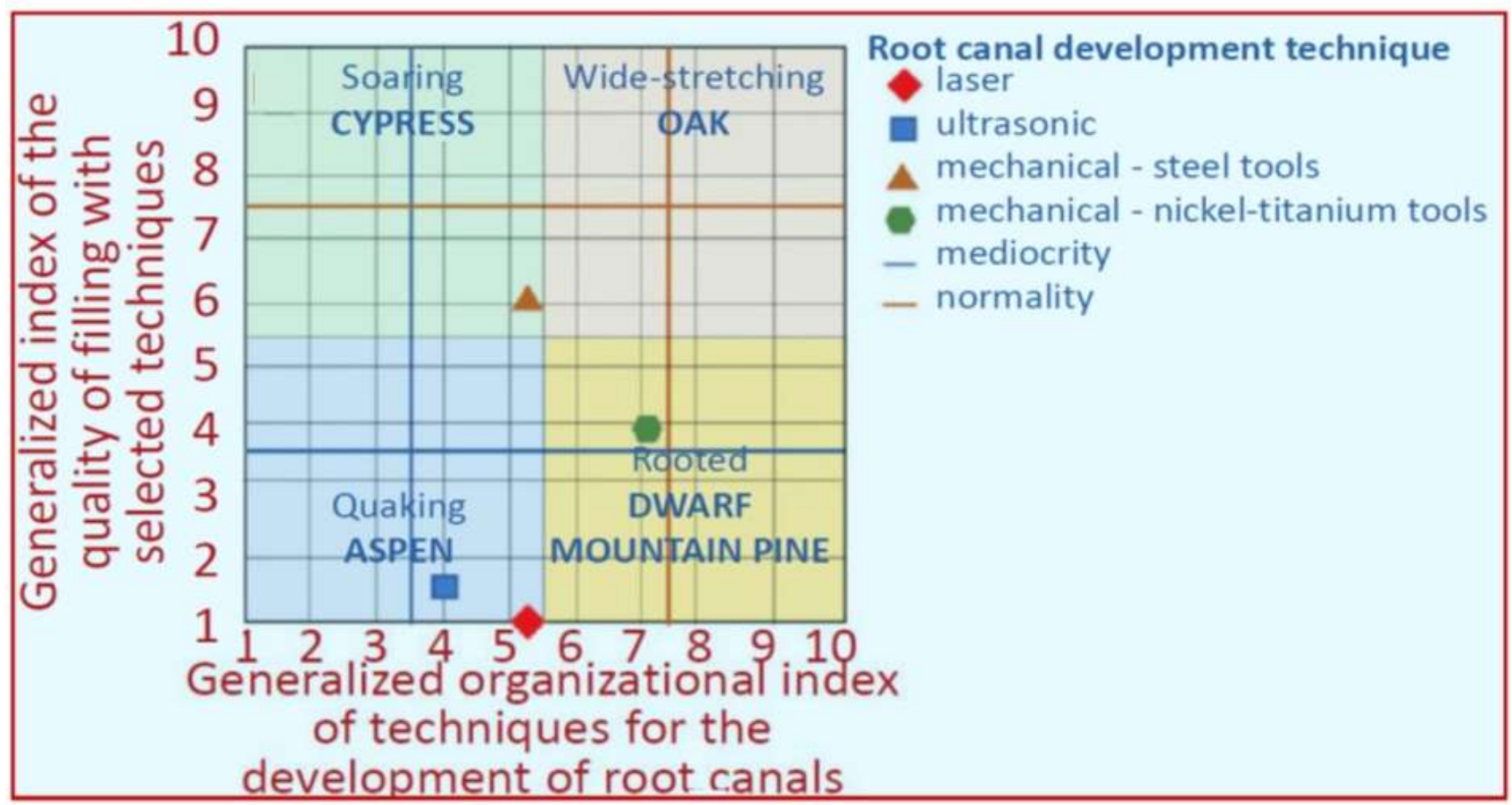

Figure 10. Contextual matrix of the attractiveness of root canal preparation techniques during endodontic treatment.

\section{Description of the Authors' Contextual Matrices Concerning the Techniques of Obturation of Root Canals}

The attractiveness of root canal filling methods should be analysed in terms of the quality of the filling and organizational aspects. The effectiveness of obturation methods was determined by first analysing the risk of pushing the material beyond the root apical. This is an important aspect of the period during which the treated tooth remains in the oral cavity without pain symptoms and lesions requiring its removal. An important element is the volume of the sealant used, because its high presence in the treated canal may result in the appearance of fissures in which bacteria develop over time and a reduction in the mechanical resistance of the root to fracture. The sealant is characterized by rapid resorption over time and, in fact, little mechanical strength. An additional analysed criterion for the evaluation of obturation methods is the possibility of filling additional tubules, which additionally reduces the risk of the occurrence of places where bacteria can develop. The last analysed criterion is the speed of applying the technique. It is a less-important feature, but due to the need to perform the procedure in cooperation with the patient experiencing pain, weariness, and fatigue, the obturation procedure should not take too long. For these reasons, this feature was included in the analysis, but with the lowest weight. The analysis in this aspect should be treated as control of the excessively long working time of the operator. Simultaneously, the speed of the procedure itself is not an aspect that distinguishes the method used. Table 4 summarizes all the described techniques of obturation, and lists the criteria and the weights assigned to them in detail, characterizing the analysed obturation techniques.

The analysis made it possible to unquestionably eliminate from detailed studies the method of filling the canal with paste as significantly different from the other methods, and the method of the central cone, which showed average values in terms of effectiveness. The cold lateral condensation technique achieved very good results in terms of the strength of the material used to fill the root canal, but only average results in terms of effectiveness. 
Table 4. The set of criteria adopted for the virtual contextual analysis concerning the selection of assessing the tightness of root canal fillings during endodontic treatment.

\section{General Descriptors}

\begin{tabular}{|c|c|}
\hline $\begin{array}{l}\text { Techniques of Root } \\
\text { Canal Obstruction }\end{array}$ & Type of Material Used \\
\hline $\begin{array}{l}\text { Filling the root canal } \\
\text { with paste }\end{array}$ & Sealant \\
\hline Central stud & Gutta-percha + sealant \\
\hline $\begin{array}{l}\text { Cold side condensation } \\
\text { Hot side condensation }\end{array}$ & $\begin{array}{c}\text { Gutta-percha or material } \\
\text { based on polyester polymeric } \\
\text { materials + sealant }\end{array}$ \\
\hline $\begin{array}{l}\text { Thermo-mechanical } \\
\text { condensation }\end{array}$ & $\begin{array}{l}\text { Gutta-percha on a compactor; } \\
\text { e.g., Quickfill + sealant }\end{array}$ \\
\hline $\begin{array}{l}\text { Gutta-percha } \\
\text { plasticized }\end{array}$ & $\begin{array}{l}\text { Gutta-percha on plastic; e.g., } \\
\text { Thermafil + sealant }\end{array}$ \\
\hline $\begin{array}{l}\text { Thermo-hydraulic- } \\
\text { condensation }\end{array}$ & $\begin{array}{c}\text { Gutta-percha or material } \\
\text { based on polyester polymeric } \\
\text { materials + sealant }\end{array}$ \\
\hline
\end{tabular}

Criteria For Determining
the Generalized Quality Index
of the Root
Canal Obturation
Technique
Effectiveness

Criteria for

Determining the

Generalized Index

of Material Strength

Applied in Root

Canal Obturation Techniques
Additional Devices

Lentulo needle

Cold plugger

Hot plugger + cold plugger

Caecum

Heating furnace; e.g., TermaPrep

Hot plugger, cold plugger, hot gutta-percha feeding device; e.g., System B + Obtura III

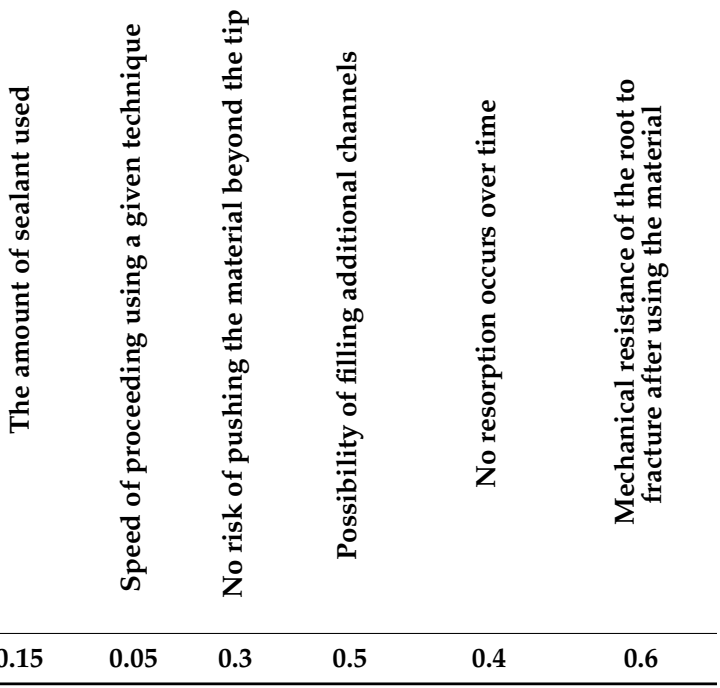

Weight

The analysis shows that the lateral heat condensation of the root canal filling with material based on gutta-percha plasticized on a plasticizer achieved better results than other methods. The most attractive technique of root canal obturation turns out to be the Thermo-Hydraulic-Condensation (THC) technique, which obtained the best results both in terms of effectiveness and strength. The matrix of the attractiveness of root canal obstruction techniques is presented in Figure 11.

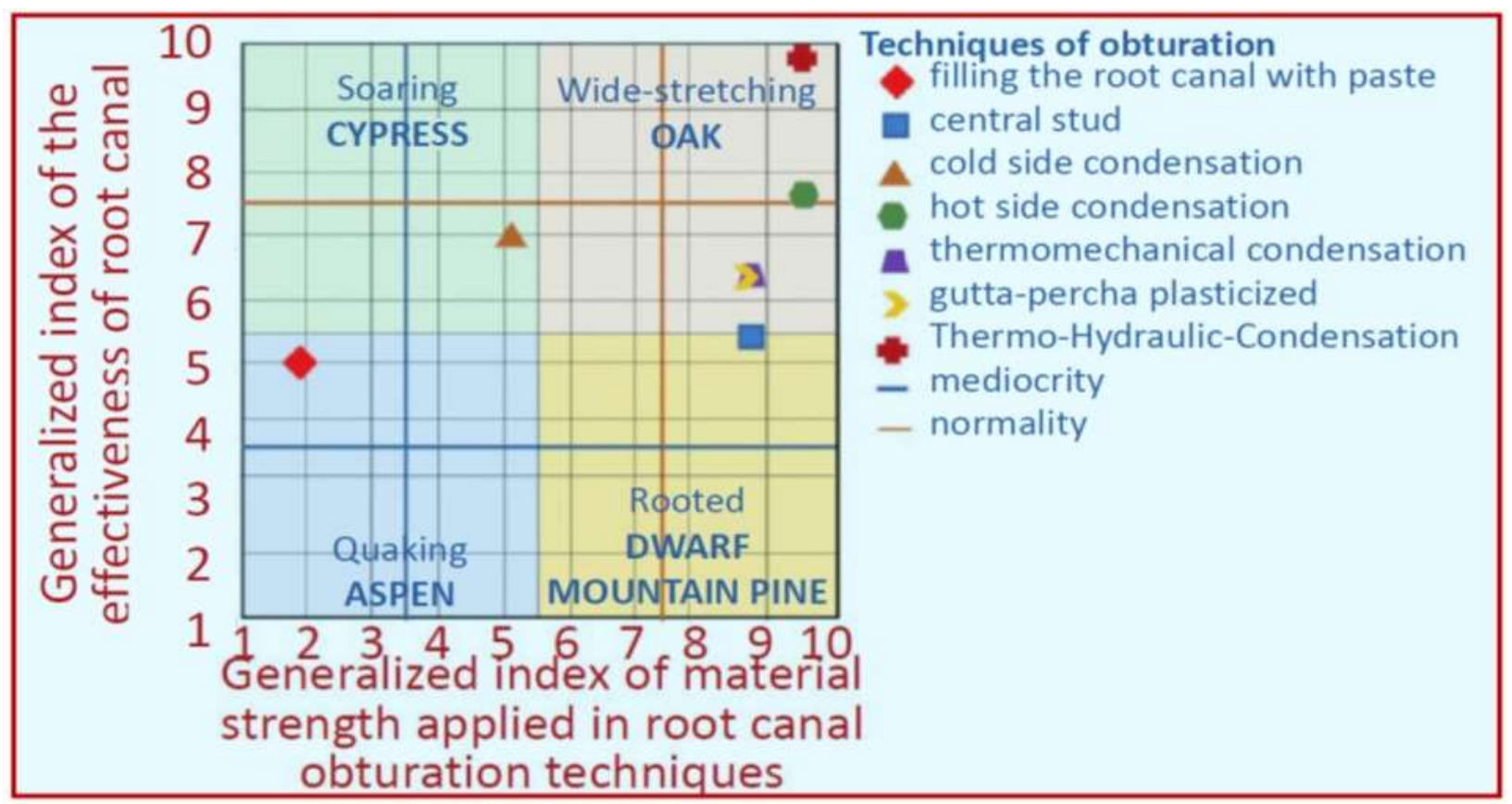

Figure 11. Contextual matrix of the attractiveness of root canal obturation techniques during endodontic treatment. 


\section{Description of the Authors' Contextual Matrices Concerning the Methods of Assessing the Effectiveness of Fillings}

An analysis was made of which techniques worked best when using the analysed filling materials in combination with organic material. The techniques that were analysed are used on a large scale in dentistry, as well as in other fields of knowledge, mainly in material engineering, and are possible to implement in endodontics to select the best methods for assessing the tightness of root canal fillings. The visualization methods were compared with other methods described in the literature [132], taking into account the effectiveness of the tests performed and organizational conditions to assess the validity of the choice of evaluating the tightness of root canal fillings. The effectiveness of the research was analysed, which was significant from the point of view of the obtained results, depending on the incurred organizational expenses necessary to conduct the research. For this purpose, a generalized test effectiveness index was created that consisted of equal parts: the effectiveness and sensitivity of the tests performed, assessed based on the literature, and the accuracy of the determination, which should be understood as the method of evaluating the filling of the canal and the suitability of the tested test method for quantifying the leakage at the border root canal fillings and walls. The second indicator used for this analysis was the generalized indicator of organizational conditions. As part of this issue, the procedure for preparing the specimen for the test; the course of the test, including the invasiveness of the analysed method; and the costs of conducting the test, including the costs of materials, investment costs, and the costs of the entire research equipment, were analysed. The attractiveness of the methods of assessing the quality of root canal fillings was checked in terms of the quality of the filling and organizational aspects. Table 5 summarizes all the described methods of tightness testing on the border of the root canal filling and wall, and specifies the criteria for the effectiveness of the tests and organizational conditions. The graph was also supplemented with a graphic border between normality and average, which facilitated the analysis of the presented results. Simultaneously, the boundary of the excellence group has not been given, but the maximum values shown in the graph are the boundary of excellence.

Table 5. The set of criteria adopted for the virtual contextual analysis concerning the selection of techniques of obturation during endodontic treatment.

\section{General Descriptors}

Investigation Method

\section{Fluent transport model}

Brightening technique

Dye penetration

Penetration of bacteria/metabolites

Electrochemical

penetration of labelled radioisotopes

Glucose penetration

Light microscope

Stereoscopic microscope

Scanning electron microscope

Confocal laser microscope
Criteria for Determining the Generalized Index of Organizational Conditions of Assessed Investigations Methods
Criteria for

Determining the

Generalized Index

Investigations Effectiveness

$$
\text { Weight }
$$

Dี

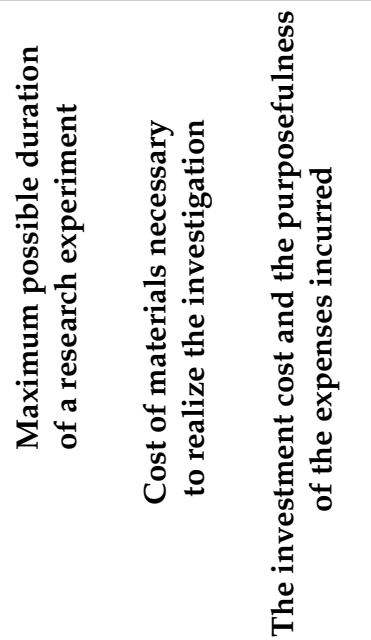


The weighted scoring analysis conducted allowed for the conclusion that quantitative methods obtained the lowest scores, including the liquid transport model, lightening technique, dye penetration test, test of bacterial penetration and their metabolites, glucose penetration test, and a method using an optical microscope, for which it should be said that they are of marginal importance and, as they have the little prospect and poor prospects for the future, they were not used in the further part of the research presented in the series of publications.

The analysis showed that among the methods for assessing the tightness of root canal fillings presented on the attractiveness matrix, the highest values and a clear advantage over other methods in terms of effectiveness were obtained by visualization methods using materialographic microscopes. The advantage of visualization methods is obtaining a sufficiently high resolution with which the tested preparations can be observed, which absolutely determines the observations' details and allows the measurement of the observed changes. Simultaneously, in these methods, it is possible to undoubtedly determine the type and details of the tested material, which also allows assessing how the sealant and the filling material are positioned in the channel being filled. Thanks to these methods, one obtains complete knowledge of the content of the filled channel.

All available materialographic microscopes were used in the research, including the ZEISS automated Stereo Discovery V12 stereoscopic light microscope with an HRC camera, the LSM Exciter confocal laser microscope for materialographic examinations based on the Axio Observer microscope by ZEISS (sources: HeNe $633 \mathrm{~nm} 5 \mathrm{~mW}$, HeNe $543 \mathrm{~nm} 1$ $\mathrm{mW}$, argon 458/488/514 nm, 25 mW, V 405 nm diode), a Park Systems AFM XE-100 atomic force microscope, a SUPRA 35 high-resolution scanning electron microscope by ZEISS together with WDS, an EDS spectrometer, and an EBSD TRIDENT XM4 camera by EDAX. The assumption was made, which was confirmed experimentally, that with the use of this equipment, it is possible to test various materials, not only engineering materials, and therefore also a special group of them, which were removed human teeth filled in the root part with appropriate filling and sealing materials. The method using the light microscope obtained results on the borderline between normal and average. Separate experiments were related to the use of the confocal laser microscope and the atomic force microscope. Research with the use of these microscopes was mainly of methodological importance. Research methods using a stereoscopic light microscope, a confocal laser microscope, and a scanning electron microscope have achieved values of excellence. Therefore, they constitute the basic methods useful for the mentioned purpose in endodontics.

The best result in the analysis was obtained by using a scanning electron microscope, which has one of the highest resolutions and enables by far the best accuracy of the mapping. Using this microscope, a properly prepared specimen can be viewed with the possibility of a precise assessment of various types of materials viewed, which was of key importance in the conducted research. The sample preparation process prepared for the needs of the described research allowed for obtaining longitudinal fractures, which, without any noticeable losses, made it possible to assess the tightness of fillings in the prepared root canals.

The scanning electron microscope is useful for observing structural details on longitudinal fractures covered with a thin layer of vacuum-sputtered gold, completely invisible in the applied magnification range, ensuring electrical conductivity of the tested surface, and revealing details of the structure of the tight connection of dentin and filling material, as well as for measuring the width of the gap in in the event of its disclosure, and to identify the structure and chemical composition of sealants using the EDS (energy dispersive spectrometer) analyser.

Materialographic analysis with the use of a stereoscopic light microscope was used to observe the general view of the examined teeth after decalcification, where the course of the root canal filling was revealed, as well as two canals in the two-canal tooth, the root delta, and the course of the lateral canals. This preparation method, despite the fact that it lasted several weeks, allowed for very interesting research results. The stereoscopic 
light microscope was also useful for the observation of fractures, including longitudinal fractures, and was the most useful due to the adopted technique of measuring the identified gaps between the dentin and the filling material, and between the dentin and the sealant.

Materialographic examinations require proper specimen preparations to enable the observation of the examined teeth. For observation with a stereoscopic light microscope, materialographic specimens were prepared on longitudinal sections, or after the transverse cutting of the teeth filled with filling material, by embedding in a thermosetting resin and mechanical grinding successively on abrasive papers with smaller and smaller grain size, and then on diamond pastes that had a grain size of up to $3 \mu \mathrm{m}$. As the preliminary tests showed, due to the cracks formed during the preparation of the specimens by excessive heating, the filling material was smeared on the surface and additionally penetrated the newly formed cracks, and the abrasive from abrasive papers, and perhaps also from the diamond pastes, was arranged almost parallel on the surface of the soft elements of the structure, mainly in the filling material. They provided an example, along with other similar experiments on other preparations, that materialographic examinations are not a useful technique for preparing specimens to determine the effectiveness of root canal obturation, which practically eliminated the possibility of using this type of preparation. Therefore, the number of tests using this technique was limited, and the recording of results was limited to only methodically necessary cases. While the preparation of specimens for testing using an atomic force microscope did not require any extraordinary measures, in the case of leakage between the dentin and the seal, it posed a unique threat to the equipment. In the course of the described tests, the scanning probe blade was broken twice, jammed in the deep but narrow opening of the gap between the dentin and the filling.

The use of such specialized research equipment, especially a scanning electron microscope, requires a complex technical base and specialist knowledge necessary to operate the research equipment. The relatively unfavourable elements of the evaluation of this method included limited access to such research equipment, the purchase of which is very expensive, and the use of which requires extensive knowledge and high skills. However, we also considered that the analysis concerns the performance of research that can be carried out across multiple disciplines, and equipment of this type is found in many universities. In industrial laboratories, it can be concluded that this is not a context that disqualifies this method from research for endodontics. In the performed analysis, all organizational aspects were assessed. It can be concluded that the incurred labour and financial inputs are compensated by the high quality of the research results obtained.

The methodological studies reported in this chapter and the examples presented in it indicate the possibility of performing materialographic tests using all five analysed microscopes. The most effective way is to select the preparation of longitudinal fractures as the appropriate methodology for preparing teeth for materialographic observations, preferably using automated materialography, a stereoscopic light microscope, and a highresolution scanning electron microscope. Figure 12 shows the attractiveness matrix for the assessment of the tightness of root canal fillings. 


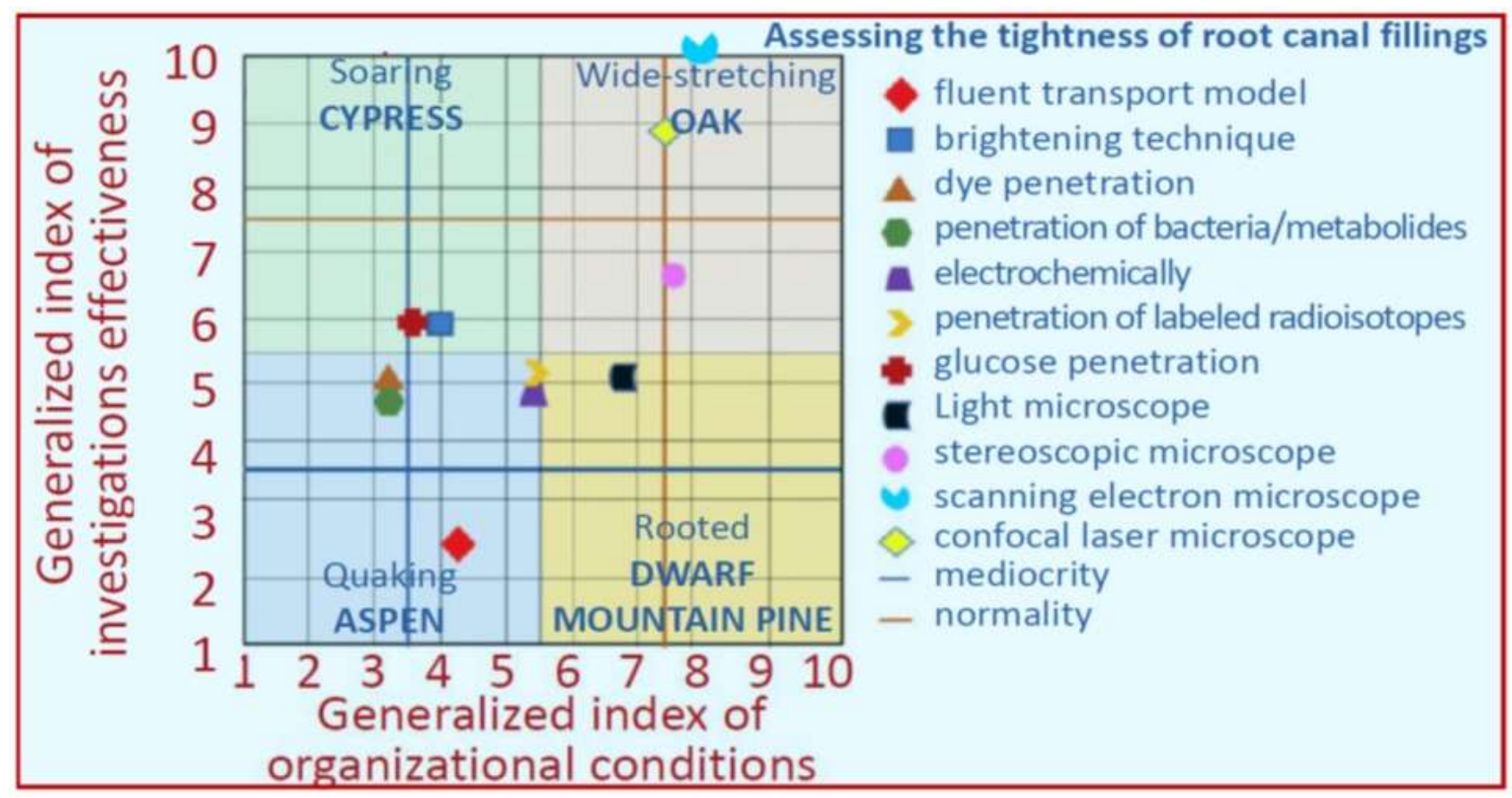

Figure 12. Matrix of attractiveness for the assessment of tightness of root canal fillings.

Measurements of the width of the gaps between the root canal wall and the filling material were made using scanning electron microscope tests in the magnification range of 1000-5000× and the microscope software, which had a built-in mechanism for measuring the distance between two markers set by the operator. The width of the gap is a measure of the effectiveness of the treatment endodontic. Tight filling of the apical section is extremely important during endodontic treatment because it is the last barrier that protects the periapical tissues against possible bacterial infection penetrating the canal from the side of the leaky cavity in the tooth chamber. The assessment of the tightness of the root canal filling was first made by determining whether the filling leaks were present and how numerous they were in any of the three sections of the root canals: parapillary, middle, and apical. Moreover, the number of leaks in these three segments was summarized, as their sum indicated the quality of the filling in the entire tooth. In addition, it was necessary to establish:

1. The number of leaks along the entire length of the root canal;

2. A representative value characterizing the mean dimensions of such leakage.

A comparative analysis of the width of the slots was also performed, and the results of the measurements of these widths were statistically analysed. The following calculations were made:
1. Mean value;
2. Standard deviation;
3. Confidence interval with the assumed significance level of 0.95 ;
4. Mean difference significance test.

The "Statistica 13" program was used to perform the calculations, while the charts were prepared using the "MS Excel 365" program. The calculations results are presented in the graphs.

\section{Experimental Verification and Examples of the Application of the Selected Methods to Evaluate the Effectiveness of Root Canal Filling}

This section of the paper presents the results of in vitro experimental studies to confirm the possibility and correctness of selecting methods for assessing the effectiveness of root canal fillings performed in the virtual analysis mode with the use of comparative matrices. 
In vitro studies included 80 single-canal incisors in the maxilla, maxillary, and mandibular canines, and maxillary and mandibular single-canal premolars removed for orthodontic, prosthetic, and periodontal indications. Among these teeth, two sets of 32 and 48 teeth, and 5 groups, each containing 16 teeth, were identified below. Immediately after extraction, the test material was placed in $0.2 \%$ chloramine solution for $24 \mathrm{~h}$, then rinsed and transferred to distilled water. These teeth were selected after the rejection of approximately $25 \%$ of the preprepared single-canal teeth not meeting the established requirements. In particular, teeth with a damaged root part were excluded from the study due to fractures, cracks, or root resorption, as well as teeth from adolescent patients with incomplete development of the apical part of the root or teeth damaged during sample fractures, which was revealed only during the examination with the use of light stereoscopic microscopy methods. Correctly selected single-canal teeth were prepared and filled with the assumptions described in this paper. Before processing, each tooth was cleaned and rinsed in $0.9 \% \mathrm{NaCl}$ solution, and then the tooth crowns were cut off at the height of the tooth neck with a diamond separator placed on the prosthetic handpiece. During the mechanical preparation of the root canals, a lubricant containing glycerin, sodium edetate, and urea peroxide RC-Prep (Premier) was used. The task of the lubricant during the preparation of the canal was to remove the smear layer covering the canal dentine and facilitate the mechanical preparation of the canal with the tools used. Between each instrument subsequently introduced into the root canal, irrigation with $2.25 \%$ sodium hypochlorite solution and $0.9 \%$ saline solution was performed alternately.

Among all prepared teeth, two sets were specified due to the preparation of root canals with hand or rotary tools. Then, five groups were completely separated due to the filling material and the method of obturation.

A 32-tooth set of 2 groups was processed with hand tools (ProTaper, Dentsply/Maillefer). Each canal was prepared in two stages. In the first stage, the peritoneal part was widened with the S1 tool, then the SX tool with the highest 19\% taper was inserted into the same part of the canal, after which the length of the canal was measured with a 10 ISO Kerr file, from which $1 \mathrm{~mm}$ was subtracted. The working length was determined based on the length of the tooth canal minus $1 \mathrm{~mm}$ (as the average distance between the anatomical apex and the physiological narrowing of the root canal). The channel was subsequently developed to the full working length with the S1 and S2 tools. The next four tools, numbered F1, F2, F3, and F4, were introduced to the full working length, widening and smoothing the root canal walls. Each instrument introduced was followed by a channel recapitulation with the Kerr tool. As a result of the development and filling of root canals, the research material selected according to the previously mentioned principles was divided into five groups.

The second set of 48 teeth, consisting of 3 groups, was developed with rotary tools up to an ISO size of 40 using the X-Smart endodontic micromotor (DentSply/Maillefer). Of these teeth, 16 were processed with hand tools (ProTaper, DentSply/Maillefer), and the remaining 32 teeth were processed with K3 tools (Sybron Endo). Each channel was developed in two stages. In the first stage, the canal mouth was developed using K3 tools with the symbols $10 / 25$ and $08 / 25$, with a tool taper of 10 and $8 \%$, respectively. Then, the root canal length measurement was performed by inserting a 10 ISO Kerr file and subtracting from the full length of $1 \mathrm{~mm}$, determining the working length as the average distance between the anatomical apex and the physiological narrowing of the root canal. Subsequently, the canal was developed to the full working length with tools in sizes of $0.4 / 20,0.4 / 25,0.4 / 30,0.4 / 35$, and $0.4 / 40$. Each instrument introduced was followed by a channel recapitulation with the Kerr tool.

In two groups, 32 teeth were filled with the method of lateral condensation. In the first group, the canals were filled with the lateral condensation method, and the filling material was made of a material based on a gutta-percha matrix. After drying the root canal, a F4 size gutta-percha point (DentSply/Maillefer) stud was fitted, corresponding to the last tool used to prepare the canal to the full working length. Before obturation, each canal was thoroughly dried with paper points. A thin layer of sealant (AH Plus 
type, DentSply/Maillefer) was applied to the walls with a paper filter in each canal. Each stud made of a material based on gutta-percha was decontaminated in $2.25 \%$ sodium hypochlorite solution and then placed in the root canal on the full, previously determined working length. Then, due to the large convergence of the main cone, which corresponded to the variable taper of the ProTaper tool, an expander with the size of 20 ISO, with a taper of $2 \%$, was selected. If using a silicone stopper, a length $1 \mathrm{~mm}$ shorter than the length on which the main stud was inserted was determined for the plugger. After the placement prepared by the manual pusher, the canal was supplemented with studs made of gutta-percha matrix material with a convergence of $2 \%$ in the size corresponding to the pusher used. The filling of the canal was completed when it was impossible to insert the expander into the canal.

In the second group, the teeth were filled with the lateral condensation method; the filling materials were Resilon points based on polyester polymer materials (RealSeal, SybronEndo) with a convergence of $4 \%$ and $2 \%$, respectively. Because the sodium hypochlorite solution may negatively affect the bond strength, each canal was thoroughly rinsed with $0.9 \%$ saline solution before drying to neutralize the residual hypochlorite. Before obturation, each canal was thoroughly dried with paper points. A root stud (RealSeal, SybronEndo) with a taper of $4 \%$ was fitted to each canal, corresponding to the apex of the last MAF instrument to prepare the canal. Then, the self-etching conditioner included in the kit (RealSeal, SybronEndo) was applied to the root canal walls with a paper filter. Then a thin layer of sealant (RealSeal, SybronEndo) was placed on the canal walls with a paper filter, and a previously selected main stud was inserted into the canal. A 20 ISO plugger with a taper of $2 \%$ was chosen successively.

Similar to inside condensation, a length of $1 \mathrm{~mm}$ shorter than the length on which the main stud was inserted was established using a silicone stopper on the pusher. After the manual plugger had prepared the site, the canal was supplemented with studs (RealSeal, SybronEndo) with a taper of $2 \%$ in the size corresponding to the plugger used. After filling the canal, the mouth of the canal was irradiated with the light of a polymerization lamp for $40 \mathrm{~s}$ to immediately seal the canal from the outlet side.

In the third group, the teeth were filled with the thermoplastic method using the Thermafil-type system, which began with selecting the appropriate size of this system from a material based on gutta-percha with the use of a verifier. The canals were checked with a 40 ISO verifier because the last instrument introduced during root canal preparation was 40 ISO. After selecting the appropriate Thermafil-type obturator, the working length was marked with a stopper, disinfected in 2.25\% sodium hypochlorite solution, dried, and placed in a ThermaPrep Plus oven to plasticize it. A thin layer of AH Plus sealant (DentSply/Maillefer) was applied to the walls with a paper filter for each canal. After the gutta-percha was plasticized in the oven, the Thermafil-type obturator was slowly withdrawn from the oven elevator and placed in the channel to the working length previously determined, maintaining a constant pressure on the polymer support for a few seconds. When placing the obturator, care was taken that it was accurately inserted centrally into the canal to prevent and distort the material in the gutta-percha matrix at the top of the obturator. The polymeric material carrier on the gutta-percha matrix was then cut off with a Therma-Cut drill without water cooling at 300,000 rpm. The gutta-percha matrix material was condensed around the carrier with a plugger.

In the case of the next two groups, containing 32 teeth in total, they were filled with a thermoplastic method using System B and Obtura III devices (SybronEndo).

In the fourth group, the teeth were filled with studs and pellets made of material based on gutta-percha. The root canals were thoroughly dried with paper points. Then the main stud was selected from material on a gutta-percha matrix with a convergence of $4 \%$. The selection criterion was the wedging of the stud in the periapical area after its introduction to its full working length. The Buchanan plugger (SybronEndo, size 1) was subsequently fitted to the canal's diameter, and its length was marked with a stopper, equal to the working length shortened by $4 \mathrm{~mm}$. AH Plus sealant (DentSply/Maillefer) was 
applied with a paper filter to cover the root canal walls. During the introduction of the heated System B plugger through the gutta-percha-based stud placed in the root canal to the length marked with a stopper, the temperature was set at $200{ }^{\circ} \mathrm{C}$. After $3 \mathrm{~s}$, the heating was turned off while maintaining the pressure of the tool towards the root apex for $10 \mathrm{~s}$. The plugger was then reheated to $300{ }^{\circ} \mathrm{C}$ and immediately removed along with any excess noncondensed material on the gutta-percha matrix. The apical portion of the material on the gutta-percha matrix was condensed for the next $10 \mathrm{~s}$ with pulsating movements using a cold, previously selected Buchanan-type plugger (SybronEndo). The canal, filled in this way at the apex, was supplemented with gutta-percha matrix material and fed into the canal using the Obtura III system (SybronEndo). The temperature was set at $160{ }^{\circ} \mathrm{C}$. The canal was supplemented in stages by introducing small portions of liquid material on a gutta-percha matrix, each time condensing with a Buchanan-type plugger (SybronEndo). The sequence of root canal preparation and obturation using this methodology has already been presented in Figure 4.

In the fifth group, the teeth were filled with studs and pellets made of Resilon based on polyester polymeric materials (RealSeal, SybronEndo) using System B and Obtura III devices (SybronEndo). The canals were thoroughly rinsed with $0.9 \%$ saline solution to neutralize any residues. Subsequently, the main pin of the RealSeal-type (SybronEndo) with a taper of $4 \%$ was selected so that when introduced to the full working length, there was a wedging of the cone in the periapical area. Primer material was attached to the RealSeal kit (SybronEndo). A thin layer of RealSeal sealant (SybronEndo) was placed on the canal walls with a paper filter, and a previously selected stud was inserted into the canal (Figure 4).

Microscopic methods were used, adapted from materials science, to assess the tightness of the root canal fillings according to the methods described above, including a stereoscopic light microscope, a confocal laser microscope, an atomic force microscope, and a scanning electron microscope. The preparations for the tests were prepared using various available techniques; i.e., as decalcified teeth, transverse and longitudinal materialographic specimens, and longitudinal fractures. To prepare the specimens for materialographic tests, after the canals were tightly filled with each technique, the root canal orifices of the selected teeth were secured with Ketac Molar glass ionomer cement (3 M ESPE). For the next seven days, the teeth were stored in a humid environment at room temperature to bind the sealant. Each tooth was wrapped in gauze soaked in physiological saline and tightly closed in plastic containers. The prepared samples were incised longitudinally along the root to a depth of $1 \mathrm{~mm}$ using a diamond disc placed on a prosthetic handpiece. The research material was placed in liquid nitrogen, and then a breakthrough was made. Fifteen samples with a correctly made longitudinal fracture were selected for each of the research groups. The samples prepared in this way were subjected to preliminary examinations in the papillary, medial, and apical sections of the root canal on a Stereo Discovery V12 stereo microscope with a Zeiss AxioCam HRC digital camera. The test results were documented using digital photography at $50 \times$ magnification (Figure 13). 


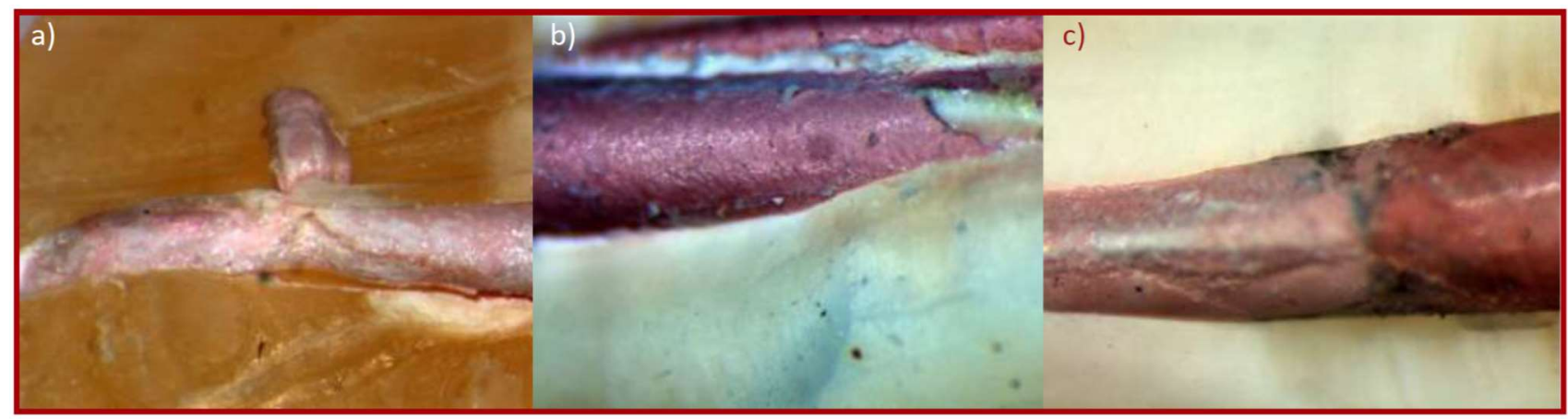

Figure 13. Results of observations in a light stereoscopic microscope of teeth after filling the root canal with filling material based on polymeric Resilon-type polyester materials, covered with a thin intermediate layer of sealant: (a) lateral canal filled with a thermoplastic method $(50 \times)$; (b) joining the main stud with the complementary studs with a sealant in the middle part of the root canal after filling with the cold lateral condensation method $(50 \times)$; (c) joining the main stud with the filling material, sealed with a thin layer of sealant in the middle part of the root canal after filling with the thermoplastic method $(50 \times)$.

Five teeth filled with material based on gutta-percha with AH Plus sealant using the thermoplastic method using System B and Obtura III devices were immersed for 14 days in an aqueous solution consisting of $7 \%$ formic acid, 3\% hydrochloric acid, and $8 \%$ sodium citrate. The samples were then rinsed thoroughly under running water to eliminate acid, and then immersed in $99 \%$ acetic acid for $12 \mathrm{~h}$, and the samples were rinsed thoroughly with distilled water. Then, the samples were dehydrated in ethanol solutions of successively increasing concentrations of 25,50,70,90, 95, and 100\%, each for $30 \mathrm{~min}$. Then the samples were stored in methyl salicylate and observed in the Stereo Discovery V12 stereoscopic light microscope with the AxioCam HRC digital camera by Zeiss at 8-50× magnification, to three-dimensional observation of the root canal lumen filled with a substitute material, with careful consideration of the root delta and its complicated internal system and side branches of the main canal (Figure 14).

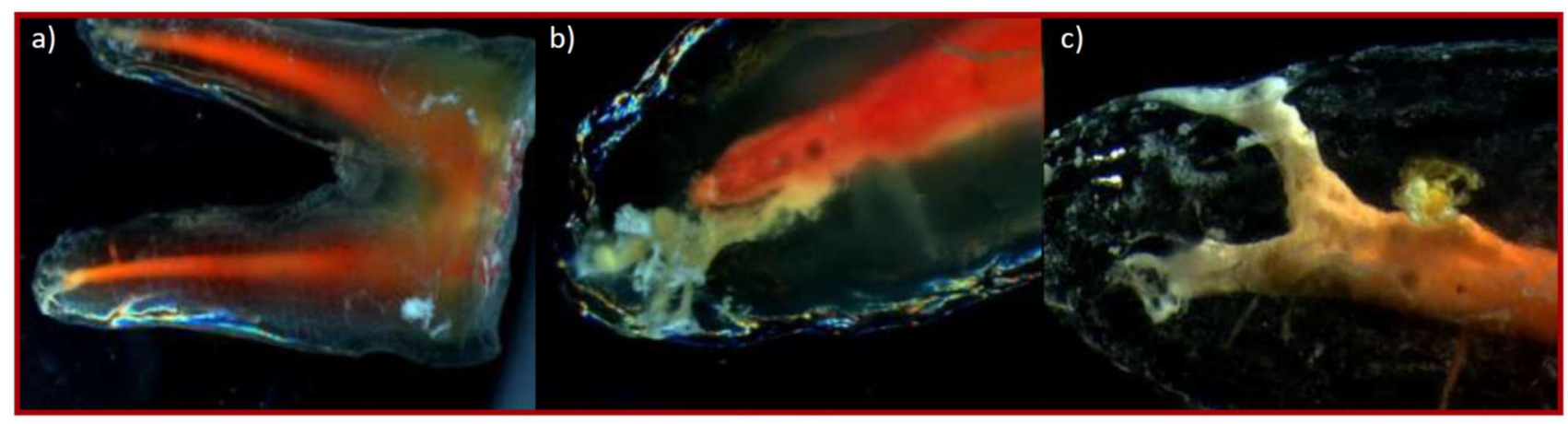

Figure 14. Results of observations in a light microscope of teeth after filling the root canal with thermoplastic gutta-percha studs prepared with the decalcification technique: (a) view of a two-root tooth with a root delta in each root and a lateral branch of the root canal in the lower part of the image $(8 \times)$; (b) view of the root of the tooth with the delta-filled complex structure of the root canal filled with sealant $(50 \times)$; (c) root canal delta filled with sealant $(50 \times)$.

Each sample was sputtered with a thin layer of gold as a conductive material in an Oerlikon Balzers BAL-TEC SCD050 sputtering machine, after making longitudinal breakthroughs by cracking in liquid nitrogen. The goal of sputtering was to remove the electric charge from the surface of the sample during the scanning electron microscope test and improve the secondary electron emission factor. The longitudinal fractures sputtered with gold were subjected to quantitative analysis of the leaks between the filling material and the root canal wall using the SUPRA 35 high-resolution scanning microscope by Zeiss in the magnification range of $2000-5000 \times$, and the results were digitally archived. 
Observations were made to document the lack of discontinuities between the dentin and the layers of sealant and filling (Figure 15) and instances where such leaks appeared as local or continuous (Figure 16).

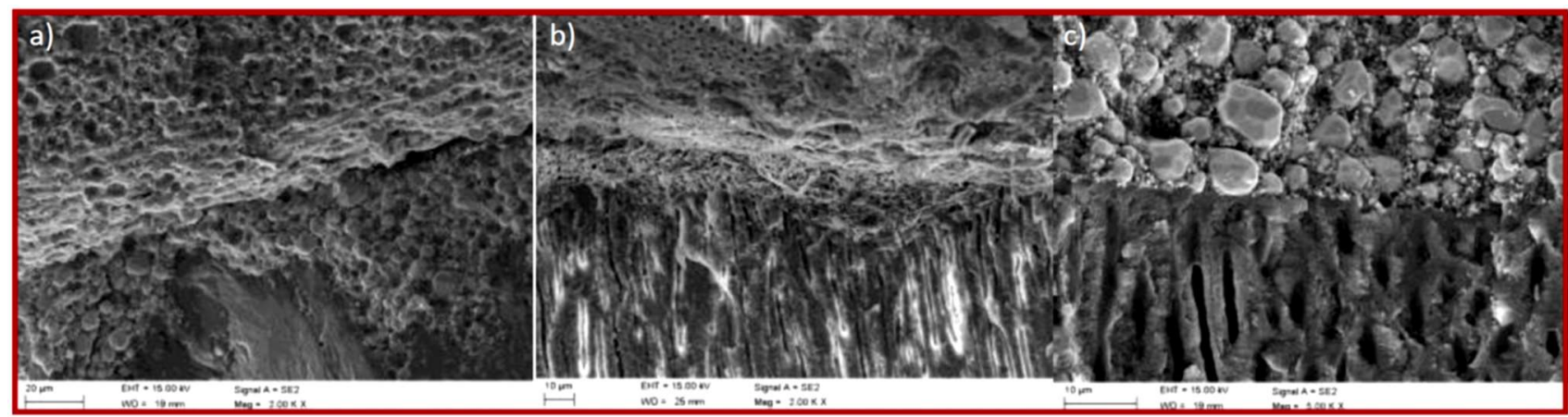

Figure 15. Scanning electron microscope view of a tooth fracture: (a) tight connection of three layers of filling material on a gutta-percha matrix covered with sealant, showing sealant and root dentine after filling with gutta-percha studs using the thermoplastic method $(2000 \times)$; (b) tight connection of the root dentine with the filling material based on Resilon-type polymer materials, covered with a thin intermediate layer of the sealant, with a thermoplastic method visible after filling with the use of studs of the Resilon-type material and a visible cross-section of the dentinal tubules along their axis transversely to the axis of the root canal $(2000 \times)$; (c) close bonding of the intermediate layer of the sealant and root canal dentin with a visible cross-section of the dentin tubules along their axis transversely to the axis of the root canal, with the method of filling and obturation as in (a) (5000×).

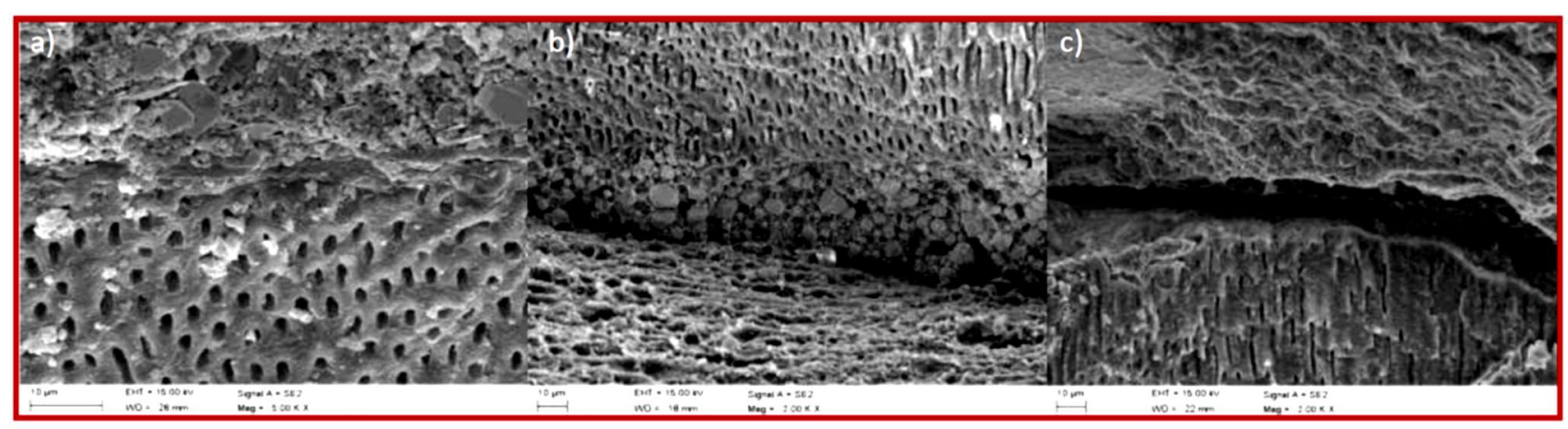

Figure 16. Scanning electron microscope view of the tooth fracture after filling the root canal by cold lateral condensation: (a) tight connection of the filling material based on Resilon-type polymer materials with the dentine of the root canal, showing fine particles of sealant $(2000 \times)$; (b) border of the connection of the three layers of root canal dentin, sealant, and filling material based on gutta-percha; leakage in two places at the border of the joint between the sealant and the filling material (2000×); (c) leakage on the border of the sealant and the dentine of the root canal, with the method of filling and obturation as $(\mathbf{b})(2000 \times)$.

Five consecutive samples—one of each group of preparations subjected to the studywere obtained by making cross-sections of these samples by cutting them on the GATAN ISOTOM device and then subjecting them to observations in the Exciter confocal laser scanning microscope by Zeiss with a $405 \mathrm{~nm}$ laser and electronic recording of test results, in which the samples were also observed, prepared as for observation in a scanning electron microscope, but not sputtered with a layer of gold (Figure 17). 


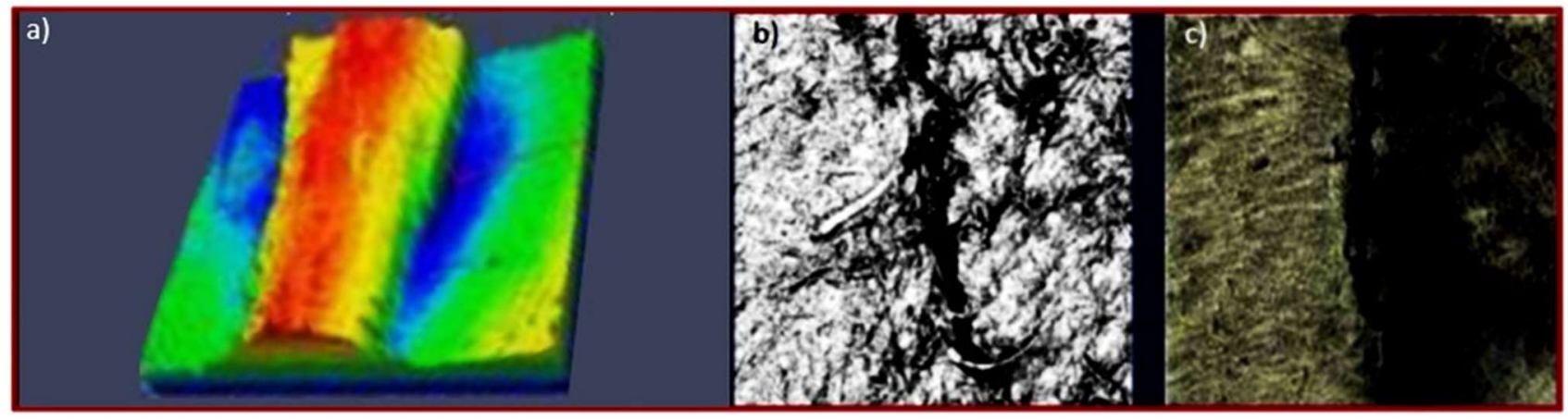

Figure 17. View in a confocal laser microscope of a tooth fracture after filling the root canal: (a) an exposed cylindrical stud with slight differences in geometrical features after filling with gutta-percha using the thermoplastic method $(20 \times)$; (b) leakage of the connection between the filling using the thermoplastic method with a filling material based on polymeric Resilon-type materials with dentin of the root canal $(2000 \times)$; (c) clear longitudinal leakage of the connection between the filling and the root dentine, with the method of filling and obturation as in (b) $(2000 \times)$.

Observations were also made using the AFM XE-100 atomic force microscope (AFM) by Park Systems with a scanning probe, using the forces of interatomic interactions and enabling the image of the surface to be obtained with a resolving power corresponding to the size of the atom (Figure 18).

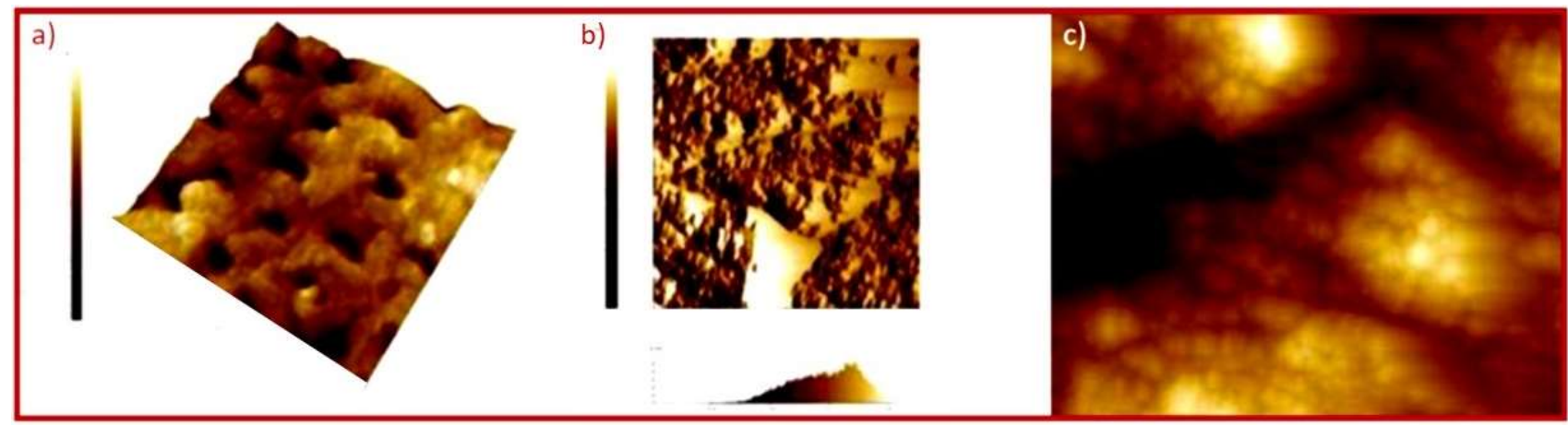

Figure 18. Microscopic surface map showing the image of the specimen surface in an atomic force microscope (a) with visible tubules and a visible connection in the dentin tubule with the filling (gutta-percha as a filling material using the thermoplastic method or sealant) $(4000 \times)$; (b) with an indication of height differences and a histogram distribution of the height of the eminence and depressions of the surface after filling the root canal using the cold side condensation method with filling material based on polymeric polyester Resilon-type materials $(4000 \times)$; (c) with visible elevations and depressions related to leaks, with the filling material and obturation method as in $(\mathbf{a})(8000 \times)$.

\section{Summary and Final Comments}

This paper aimed to develop and present the methodological assumptions of the virtual comparative analysis of biomaterials used in endodontic treatment, including the production and selection of filling and sealing materials; the selection of dental devices and tools, including specialized tools; the selection and application of the technology for the development and obturation of the root canal; and assessment effectiveness and tightness of root canal fillings as a result of endodontic treatment. Achievements and experiences from various areas of knowledge were used synergistically to achieve this goal. The motivation of the multifaceted approach and wide-ranging activities undertaken in this work, and the synergy achieved in this way in its implementation, is referred to as the motto, the thought of W.E. Deming, the creator of the idea of continuous improvement, implemented, among others, in the Japanese automotive company the Toyota Motor Corporation [331]. This, through Kaizen [332] and Total Quality Management (TQM) [333], became the basis of its global market success and, like the German concern Volkswagen AG, sells almost 
11 million passenger cars annually. The authors sought the best solution to their research and methodological problems, adopting an open and synergistic methodological approach appropriate to various and seemingly very distant scientific disciplines. The basics of quality management were used with the basic proprietary approach, contained in the slogan "Whatever you plan to do, make what is needed to do, do it right and get it done the first time". This paper dealt with clinical dentistry, especially endodontics as its branch. The knowledge and methodological experience of materials engineering, including metallography and scanning electron microscopy, was also widely used, which justifies the publication of this paper in the Special Issue on Synthesis and Characterization of Biomedical Materials. Engineering and knowledge management, including the methodology of technological foresight, as well as procedural benchmarking and comparative analysis with the use of contextual matrices, appropriately adapted methodology and research results, previously developed and published own works, concerning the analysis of many problems concerning mainly material engineering, also provided a broad view on the issues under consideration. We have referred to our own published works $[1,64,69,132,287-314]$ and other authors [315-328].

The paper concerned one of the most common and effective methods of treating oral cavity diseases as a branch of advanced interventionist dentistry within the concept of sustainable development of dentistry [1]. Endodontic treatment ensures the maintenance of the tooth in a functional state when its vital functioning is no longer possible, undertaken when symptoms of the second stage according to ICDAS of dental pulp disease appear [99-101]. The global endodontics market reached USD 1.56 billion in 2018 and is projected to grow to USD 2.1 billion by 2026, with a CAGR of $4.1 \%$ [127]. The global dental consumables market, which also applies to endodontics to some extent, in 2016 reached USD 38.921 million, while it is forecasted to reach USD 55.584 million in 2023, with a CAGR of 5.2\% [128] (Figure 3). The treatment is based on caries, as the most common infectious disease in the world, affecting 3-5 billion people [1], causing many systemic diseases [14-28], as well as personality changes leading to dementia [29-35], and if necessary the necessity to extract teeth, causing toothlessness, which may also cause many systemic complications [8-13]. However, it should be emphasized that dentists treat tooth extraction as a necessity in the event of failure to continue endodontic treatment $[103,104]$, performed carefully to avoid complications due to iatrogenic causes [53-58]. The endodontic treatment results in sealing the previously infected and then developed root canals, preventing the spread of bacteria and their toxins to the root tip [110-112], including saliva [113].

Apart from the obturation techniques presented in the form of an umbrella (Figure 2), the effectiveness of endodontic treatment depends on the proper selection of the filling material, presented in the form of ikebana [119-125]. Apart from a good fit to the geometrical features of the prepared root canal, the filling material should be biocompatible, bactericidal, sterile, and easily removable if it is necessary to repeat endodontic treatment [114,115], and should strengthen of the root [118] and not cause tooth discolouration [115-117]. For many years, the most commonly used natural material for filling root canals was gutta-percha [130-135], even considered a "gold standard", and 20 years ago, the Thermo-Hydraulic-Condensation obturation technique [140-145] significantly improved the effectiveness of root canal fillings (Figure 4). Despite this and selecting nonstandard sealing materials [118,160-163], there were suggestions of improper bonding of gutta-percha to dentin [146-155]. An alternative is a synthetic thermoplastic filler material based on polyester materials, introduced in 2004 from the company Resilon [168] with eponymous sealant $[167,174,175]$ and amenable to all obturation techniques developed for gutta-percha [168]. The competitive advantage of this material was supposed to be a monoblock with dentin [179-181], which unfortunately did not turn out to be true [182]. There has been dispute as to whether this material is more useful, as it has been recognized in some studies [168,178,184,194,211,215,216,230,232-245], or whether gutta-percha provides the best filling and tightness in the root canal [160,194-207], especially after a longer time [208,209]. Many other evaluations and research results showed, and many dentists 
still believe, that Resilon cannot compete with gutta-percha. The significant dispersion of the results of the cited studies and methodological flaws of many of them did not allow for an unambiguous formulation of conclusions, and due to the lack of sufficient clinical evidence, it is impossible to firmly confirm the possible advantage of this material over gutta-percha or even the hypothesis that both materials are equivalent.

The controversies presented above regarding the choice of the more favourable filling material and the better obturation method refer to the methodological aspects of characterizing these descriptors of the adopted methodology of clinical activities, as pointed out in, among others, the works $[156,157]$. This paper focused on the methodological aspects of the research, as the detailed results of this research were presented in a series of other publications [286]. The detailed multipoint research methodology included the theoretical analysis carried out here using procedural benchmarking and comparative analysis using contextual matrices, in addition to reviewing the literature and preliminary analyses, the assumptions of the so-called "digital twins" as an approach characteristic of Industry $4.0[64,65,67-98]$, and the resulting idea of Dentistry $4.0[62,63,66]$. The concept of the "digital twin" allows many experiments to be carried out in virtual space before the analysed product or object is physically created or made available for research, even without its physical existence. For the quantitative assessment of the analysed aspects of endodontic treatment, appropriate criteria were defined in each case, assigning them to sum up weights reflecting their significance and subsequent evaluation in each of the criteria using the universal scale of relative states (Figure 6). The positioning of the method or procedure among those covered by the analysis and their usefulness in endodontological treatment was achieved by a set of contextual matrices, containing in particular ones analogous to dendrological matrices, adopted in the foresight analysis of surface engineering technology (Figure 7), which are tools for a graphical comparative analysis of individual methods and materials or groups of them. Depending on the value of the generalized potential and the generalized level of attractiveness, which were determined as part of the expert assessment, each of the analysed objects was placed in one of the matrix quarters, which were distinguished in the dendrological value matrix, based on which it was possible to reach conclusions about its methodological success in the field of endodontics. The broad oak quarter covered the most promising aspects for future success. The soaring cypress quarter covered the objects with possible success. The rooted mountain pine quarter covered those with high probability. In contrast, the quivering aspen quarter contained the weakest objects, for which success is unlikely or impossible.

The literature analysis was based on the substantive subject of the considered criteria, interviews with dentists, and our own experience gained during dental practice. As a result of considerations, this paper presents four types of the authors' contextual matrices related to endodontics:

1. Materials selection in the coordinate system generalized index of material quality for root canal filling $(\mathrm{x})$ and generalized index of material strength in the root canal $(\mathrm{y})$;

2. Root canal development technique selection in the coordinate system of a generalized organizational index of techniques for the development of root canals $(x)$ and generalized index of the quality of filling with selected techniques (y);

3. Techniques of obturation selection in the coordinate system generalized index of material strength applied in root canal obturation techniques $(x)$ and generalized index of the effectiveness of root canal obturation techniques (y);

4. Assessing the tightness of root canal fillings selection in the coordinate system of the generalized index of organizational conditions $(x)$ and generalized index of investigations effectiveness (y).

All the analyses performed were included in this paper, along with an exemplary description of the obtained test results. The detailed test results will be included in subsequent papers from the announced series [286]. Based on the analyses performed and the analysis of the plotted dendrological matrices, a decision was made regarding detailed research on the four aspects mentioned above. At the same time, the full usefulness of 
materialographic tests with the use of a scanning electron microscope was confirmed. For this purpose, 80 single-canal incisors in the maxilla, maxillary, and mandibular canines, and maxillary and mandibular single-canal premolars, removed for orthodontic, prosthetic, and periodontal indications, were included in the in vitro tests. The research was performed after obtaining the consent of the Bioethics Committee. Among these teeth, five groups were distinguished, each containing 16 teeth, tested in identical conditions of root canal preparation, using the same filling materials and using the same obturation technique. The results of good tests using various methods were also presented as an example in this work.

The analysis results confirmed the full practical usefulness of the so-called "digital twins" in a virtual comparative analysis of biomaterials used in endodontic treatment.

\begin{abstract}
Author Contributions: Conceptualization, literature review, presentation, design, resources, data curation, software, formal analysis, writing, original draft preparation, visualization, J.D., L.B.D., L.A.D., and A.D.D.-D.; practical verification, J.D., L.B.D., and K.G., writing-review and editing, supervision, project administration, funding acquisition, L.A.D., L.B.D., and J.D. All authors have read and agreed to the published version of the manuscript.
\end{abstract}

Funding: This research was not directly financed by external funding.

Notice: This paper was prepared to actually implement Project POIR.01.01-00-0485/16-00 on "IMSKAMAT Innovative dental and maxillofacial implants manufactured using the innovative additive technology supported by computer-aided materials design ADD-MAT" realized by the Medical and Dental Engineering Centre for Research, Design, and Production (ASKLEPIOS) in Gliwice, Poland. The project was implemented in 2017-2021 and was cofinanced by the Operational Program for Intelligent Development of the European Union.

Conflicts of Interest: The authors declare no conflict of interest.

\title{
References
}

1. Dobrzański, L.A.; Dobrzański, L.B.; Dobrzańska-Danikiewicz, A.D.; Dobrzańska, J. The Concept of Sustainable Development of Modern Dentistry. Processes 2020, 8, 1605. [CrossRef]

2. Watt, R.G.; Daly, B.; Allison, P.; Macpherson, L.M.D.; Venturelli, R.; Listl, S.; Weyant, R.J.; Mathur, M.R.; Guarnizo-Herreño, C.C.; Celeste, R.K.; et al. Ending the neglect of global oral health: Time for radical action. Lancet 2019, 394, 261-272. [CrossRef]

3. Peres, M.A.; Macpherson, L.M.D.; Weyant, R.J.; Daly, B.; Venturelli, R.; Mathur, M.R.; Listl, S.; Celeste, R.K.; Guarnizo-Herreño, C.C.; Kearns, C.; et al. Oral diseases: A global public health challenge. Lancet 2019, 394, 249-260. [CrossRef]

4. Fejerskov, O. Concepts of dental caries and their consequences for understanding the disease. Community Dent. Oral Epidemiol. 1997, 25, 5-12. [CrossRef]

5. Reisine, S.; Litt, M. Social and psychological theories and their use for dental practice. Int. Dent. J. 1993, 43 (Suppl. 1), $279-287$.

6. Selwitz, R.H.; Ismail, A.I.; Pitts, N.B. Dental caries. Lancet 2007, 369, 51-59. [CrossRef]

7. GBD Compare. Viz Hub. Available online: https://vizhub.healthdata.org/gbd-compare/ (accessed on 6 April 2021).

8. Li, X.; Tornstad, L.; Olsen, I. Brain abscesses caused by oral infection. Dent. Traumatol. 1999, 15, 95-101. [CrossRef] [PubMed]

9. Scannapieco, F.A.; Bush, R.B.; Paju, S. Associations between periodontal disease and risk for nosocomial bacterial pneumonia and chronic obstructive pulmonary disease. A systemic review. Ann. Periodontol. 2003, 8, 54-69. [CrossRef]

10. Dobrzański, L.A.; Dobrzański, L.B. Dentistry 4.0 Concept in the Design and Manufacturing of Prosthetic Dental Restorations. Processes 2020, 8, 525. [CrossRef]

11. Aleksander, M.; Krishnan, B.; Shenoy, N. Diabetes mellitus and odontogenic infections-an exaggerated risk? Oral Maxillofac. Surg. 2008, 12, 129-130. [CrossRef]

12. Scannapieco, F.A. Role of oral bacteria in respiratory infection. J. Periodontol. 1999, 70, 793-802. [CrossRef] [PubMed]

13. Mueller, A.A.; Saldami, B.; Stübinger, S.; Walter, C.; Flückiger, U.; Merlo, A.; Schwenzer-Zimmerer, K.; Zeilhofer, H.F.; Zimmerer, S. Oral bacterial cultures in nontraumatic brain abscesses: Results of a first line study. Oral Surg. Oral Med. Oral Pathol. Oral Radiol. Endod. 2009, 107, 469-476. [CrossRef]

14. Buset, S.L.; Walter, C.; Friedmann, A.; Weiger, R.; Borgnakke, W.S.; Zitzmann, N.U. Are periodontal diseases really silent? A systematic review of their effect on quality of life. J. Clin. Periodontol. 2016, 43, 333-344. [CrossRef] [PubMed]

15. Sierpinska, T.; Golebiewska, M.; Dlugosz, J.W.; Kemona, A.; Laszewicz, W. Connection between masticatory efficiency and pathomorphologic changes in gastric mucosa. Quintessence Int. 2007, 38, 31-37.

16. Al-Nawas, B.; Maeurer, M. Severe versus local odontogenic bacterial infections: Comparison of microbial isolates. Eur. Surg. Res. 2008, 40, 220-224. [CrossRef] [PubMed]

17. Pallasch, T.J.; Wahl, M.J. Focal infection: New age or ancient history? Endodon. Top. 2003, 4, 32-45. [CrossRef] 
18. De Pablo, P.; Dietrich, T.; McAlindon, T.E. Association of periodontal disease and tooth loss with rheumatoid arthritis in the US population. J. Rheumatol. 2008, 35, 70-76. [PubMed]

19. Felton, D.A. Edentualism and comorbid factors. J. Prosthodont. 2009, 18, 88-96. [CrossRef]

20. Volzke, H.; Schwahn, C.; Hummel, A.; Wolff, B.; Kleine, V.; Robinson, D.M.; Dahm, J.B.; Felix, S.B.; John, U.; Kocher, T. Tooth loss is independently associated with the risk of acquired aortic valve sclerosis. Am. Heart J. 2005, 150, 1198-1203. [CrossRef] [PubMed]

21. Bagchi, S.; Tripathi, A.; Tripathi, S.; Kar, S.; Tiwari, S.C.; Singh, J. Obstructive sleep apnea and neurocognitive dysfunction in edentulous patients. J. Prosthodont. 2019, 28, e837-e842. [CrossRef]

22. Nagpal, R.; Yamashiro, Y.; Izumi, Y. The two-way association of periodontal infection with systemic disorders: An overview. Mediat. Inflamm. 2015, 2015, 793898. [CrossRef] [PubMed]

23. Abnet, C.C.; Qiao, Y.L.; Dawsey, S.M.; Dong, Z.W.; Taylor, P.R.; Mark, S.D. Tooth loss is associated with increased risk of total death and death from upper gastrointestinal cancer, heart disease, and stroke in a Chinese population-based cohort. Int. J. Epidemiol. 2005, 34, 467-474. [CrossRef] [PubMed]

24. Burzyńska, B.; Mierzwińska-Nastalska, E. Rehabilitacja protetyczna pacjentów bezzębnych. Nowa Stomatol. 2011, 4, 167-199.

25. Bui, F.Q.; Almeida-da-Silva, C.L.C.; Huynh, B.; Trinh, A.; Liu, J.; Woodward, J.; Asadi, H.; Ojcius, D.M. Association between periodontal pathogens and systemic disease. Biomed. J. 2019, 42, 27-35. [CrossRef]

26. Holmlund, A.; Holm, G.; Lind, L. Number of teeth as a predictor of cardiovascular mortality in a cohort of 7674 subjects followed for 12 years. J. Periodontol. 2010, 81, 870-876. [CrossRef] [PubMed]

27. Takata, Y.; Ansai, T.; Matsumura, K.; Awano, S.; Hamasaki, T.; Sonoki, K.; Kusaba, A.; Akifusa, S.; Takehara, T. Relationship between tooth loss and electrocardiographic abnormalities in octogenarians. J. Dent. Res. 2001, 80, 1648-1652. [CrossRef] [PubMed]

28. Felton, D.A. Complete edentulism and comorbid diseases: An update. J. Prosthodont. 2016, 25, 5-20. [CrossRef]

29. Chen, H.; Iinuma, M.; Onozuka, M.; Kubo, K.-Y. Chewing maintains hippocampus-dependent cognitive. Int. J. Med. Sci. 2015, 12, 502-509. [CrossRef]

30. Stein, P.S.; Desrosiers, M.; Donegan, S.J.; Yepes, J.F.; Kryscio, R.J. Tooth loss, dementia and neuropathology in the Nun study. J. Am. Dent. Assoc. 2007, 138, 1314-1322. [CrossRef]

31. Henke, K. A model for memory systems based on processing modes rather than consciousness. Nat. Rev. Neurosci. 2010, 11, 523-532. [CrossRef]

32. Lexomboon, D.; Trulsson, M.; Wårdh, I.; Parker, W.G. Chewing ability and tooth loss: Association with cognitive impairment in an elderly population study. J. Am. Geriatr. Soc. 2012, 60, 1951-1956. [CrossRef]

33. Hirano, Y.; Obata, T.; Takahashi, H.; Tachibana, A.; Kuroiwa, D.; Takahashi, T.; Ikehira, H.; Onozuka, M. Effects of chewing on cognitive processing speed. Brain Cognit. 2013, 81, 376-381. [CrossRef] [PubMed]

34. Onishi, M.; Iinuma, M.; Tamura, Y.; Kubo, K.Y. Learning deficits and suppression of the cell proliferation in the hippocampal dentate gyrus of offspring are attenuated by maternal chewing during prenatal stress. Neurosci. Lett. 2014, 560, 77-80. [CrossRef]

35. Kawahata, M.; Ono, Y.; Ohno, A.; Kawamoto, S.; Kimoto, K.; Onozuka, M. Loss of molars early in life develops behavioral lateralization and impairs hippocampus-dependent recognition memory. BMC Neurosci. 2014, 15, 4. [CrossRef] [PubMed]

36. Clarkson, B.H.; Exterkate, R.A.M. Noninvasive dentistry: A dream or reality? Caries Res. 2015, 49 (Suppl. 1), 11-17. [CrossRef]

37. Pitts, N.B.; Zero, D.T. White Paper on Dental Caries Prevention and Management. FDI World Dental Federation. Available online: http:/ / www.fdiworlddental.org/sites/default/files/media/documents/2016-fdi_cpp-white_paper.pdf (accessed on 6 April 2021).

38. Wierichs, R.J.; Meyer-Lueckel, H. Systematic review on noninvasive treatment of root caries lesions. J. Dent. Res. 2015, 94, 261-271. [CrossRef] [PubMed]

39. Marsh, P.D.; Head, D.A.; Devine, D.A. Prospects of oral disease control in the future-an opinion. J. Oral. Microbiol. 2014, 6, 261-276. [CrossRef] [PubMed]

40. Marthaler, T.M. A standardized system of recording dental conditions. Helv. Odontol. Acta 1966, 10, 1-18.

41. Dirks, O.B.; van Amerongen, J.; Winkler, K.C. A reproducible method for caries evaluation. J. Dent. Res. 1951, 30, 346-359. [CrossRef] [PubMed]

42. Black, G.V. A Work on Operative Dentistry: The Technical Procedures in Filling Teeth; Medico-Dental Publishing: Chicago, IL, USA, 1917; p. 5.

43. Pitts, N. "ICDAS"-an international system for caries detection and assessment being developed to facilitate caries epidemiology, research and appropriate clinical management. Community Dent. Health 2004, 21, 193-198.

44. ICDAS Website. Available online: https:/ / www.icdas.org/ (accessed on 6 April 2021).

45. Featherstone, J.D. The continuum of dental caries—evidence for a dynamic disease process. J. Dent. Res. 2004, 83, C39-C42. [CrossRef] [PubMed]

46. Ismail, A.I.; Sohn, W.; Tellez, M.; Amaya, A.; Sen, A.; Hasson, H.; Pitts, N.B. The International Caries Detection and Assessment System (ICDAS): An integrated system for measuring dental caries. Community Dent. Oral Epidemiol. 2007, 35, 170-178. [CrossRef] [PubMed] 
47. Ismail, A.; Tellez, M.; Pitts, N.B.; Ekstrand, K.R.; Ricketts, D.; Longbottom, C.; Eggertsson, H.; Deery, C.; Fisher, J.; Young, D.A.; et al. Caries management pathways preserve dental tissues and promote oral health. Community Dent. Oral Epidemiol. 2013, 41, e12-e40. [CrossRef] [PubMed]

48. Pitts, N.B.; Ekstrand, K.R. International Caries Detection and Assessment System (ICDAS) and its International Caries Classification and Management System (ICCMS) - methods for staging of the caries process and enabling dentists to manage caries. Community Dent. Oral Epidemiol. 2013, 41, e41-e52. [CrossRef]

49. Ormond, C.; Douglas, G.; Pitts, N. The use of the International Caries Detection and Assessment System (ICDAS) in a National Health Service general dental practice as part of an oral health assessment. Prim. Dent. Care 2010, 17, 153-159. [CrossRef]

50. Ismail, A.; Pitts, N.B.; Tellez, M. The international caries classification and management system (ICCMS ${ }^{\mathrm{TM}}$ ) an example of a caries management pathway. BMC Oral Health 2015, 15, S9. [CrossRef]

51. Sunay, H.; Tanalp, J.; Dikbas, I.; Bayirli, G. Cross-sectional evaluation of the periapical status and quality of root canal treatment in a selected population of urban Turkish adults. Int. Endodon. J. 2007, 40, 139-145. [CrossRef]

52. Tsuneishi, M.; Yamamoto, T.; Yamanaka, R.; Tamaki, N.; Sakamoto, T.; Tsuji, K.; Watanabe, T. Radiographic evaluation of periapical status and prevalence of endodontic treatment in an adult Japanese population. Oral Surg. Oral Med. Oral Pathol. Oral Radiol. Endod. 2005, 100, 631-635. [CrossRef]

53. Lazarski, M.P.; Walker, W.A.; Flores, C.M.; Schindler, W.G.; Hargreaves, K.M. Epidemiological evaluation of the outcomes of nonsurgical root canal treatment in a large cohort of insured dental patients. J. Endodon. 2001, 27, 791-796. [CrossRef]

54. Chen, S.C.; Chuech, L.H.; Hsiao, C.K.; Tsai, M.Y.; Ho, S.C.; Chiang, C.P. An epidemiologic study of tooth retention after nonsurgical endodontic treatment in a large population in Taiwan. J. Endodon. 2007, 33, 226-229. [CrossRef]

55. Meuwissen, R.; Eschen, S. Twenty years of endodontic treatment. J. Endodon. 1983, 9, 390-393. [CrossRef]

56. Kirkevang, L.L.; Horsted-Bindslev, P.; Orstavik, D.; Wenzel, A. Frequency and distribution of endodontically treated teeth and apical periodontitis in an urban Danish population. Int. Endodon. J. 2001, 34, 198-205. [CrossRef]

57. Salehrabi, R.; Rotstein, I. Endodontic treatment outcomes in a large patient population in the USA: An epidemiological study. J. Endodon. 2004, 30, 846-850. [CrossRef] [PubMed]

58. Hayashi, M.; Haapasalo, M.; Imazato, S.; Il Lee, J.; Momoi, Y.; Murakami, S.; Whelton, H.; Wilson, N. Dentistry in the 21st century: Challenges of a globalising world. Int. Dent. J. 2014, 64, 333-342. [CrossRef] [PubMed]

59. Dobrzański, L.B.; Dobrzański, L.A.; Dobrzańska, J.; Rudziarczyk, K.; Achtelik-Franczak, A. Akcesorium do ochrony osobistej personelu dentystycznego przed koronawirusem SARS-CoV-2 i innymi drobnoustrojami chorobotwórczymi. Zgłoszenie Pat. 2020, 434391.

60. Galicia, J.C.; Mungia, R.; Taverna, M.V.; Mendoza, M.J.; Estrela, C.; Gaudin, A.; Zhang, C.; Vaughn, B.A.; Khan, A.A. Response by Endodontists to the SARS-CoV-2 (COVID-19) Pandemic: An International Survey. Front. Dent. Med. 2021, 1, 1-24. [CrossRef]

61. Ates, A.A.; Alomari, T.; Bhardwaj, A.; Tabnjh, A.; Gambarini, G. Differences in endodontic emergency management by endodontists and general dental practitioners in COVID-19 times. Braz. Oral Res. 2020, 34, 1-11. [CrossRef] [PubMed]

62. Dobrzański, L.A.; Dobrzański, L.B. Approach to the Design and Manufacturing of Prosthetic Dental Restorations According to the Rules of Industry 4.0. Mater. Perform. Charact. 2020, 9, 394-476. [CrossRef]

63. Dobrzański, L.A.; Dobrzańska-Danikiewicz, A.D.; Dobrzański, L.B. Effect of Biomedical Materials in the Implementation of a Long and Healthy Life Policy. Processes 2021, 9, 865. [CrossRef]

64. Dobrzański, L.A.; Dobrzański, L.B.; Dobrzańska-Danikiewicz, A.D. Overview of conventional technologies using the powders of metals, their alloys and ceramics in Industry 4.0 stage. JAMME 2020, 98, 56-85. [CrossRef]

65. Dobrzański, L.A. Role of materials design in maintenance engineering in the context of industry 4.0 idea. JAMME 2019, 96, 12-49. [CrossRef]

66. Dobrzański, L.A.; Dobrzański, L.B.; Achtelik-Franczak, A.; Dobrzańska, J. Application Solid Laser-Sintered or Machined Ti6Al4V Alloy in Manufacturing of Dental Implants and Dental Prosthetic Restorations According to Dentistry 4.0 Concept. Processes 2020, 8, 664. [CrossRef]

67. Dobrzański, L.A.; Dobrzańska-Danikiewicz, A.D. Applications of Laser Processing of Materials in Surface Engineering in the Industry 4.0 Stage of the Industrial Revolution. Mater. Perform. Charact. 2019, 8, 1091-1129. [CrossRef]

68. Dobrzański, L.A.; Dobrzańska-Danikiewicz, A.D. Why Are Carbon-Based Materials Important in Civilization Progress and Especially in the Industry 4.0 Stage of the Industrial Revolution. Mater. Perform. Charact. 2019, 8, 337-370. [CrossRef]

69. Dobrzański, L.A.; Dobrzański, L.B.; Dobrzańska-Danikiewicz, A.D.; Kraszewska, M. Manufacturing powders of metals, their alloys and ceramics and the importance of conventional and additive technologies for products manufacturing in Industry 4.0 stage. AMSE 2020, 102, 13-41. [CrossRef]

70. Hermann, M.; Pentek, T.; Otto, B. Design Principles for Industrie 4.0 Scenarios: A Literature Review; Technische Universität Dortmund: Dortmund, Germany, 2015.

71. Kagermann, H.; Wahlster, W.; Helbig, J. Recommendations for Implementing the Strategic Initiative INDUSTRIE 4.0: Final Report of the Industrie 4.0 Working Group; Federal Ministry of Education and Research: Bonn, Germany, 2013.

72. Rüßmann, M.; Lorenz, M.; Gerbert, P.; Waldner, M.; Justus, J.; Engel, P.; Harnisch, M. Industry 4.0: The Future of Productivity and Growth in Manufacturing Industries; Boston Consulting Group: Boston, MA, USA, 2015.

73. Kagermann, H. Chancen von Industrie 4.0 Nutzen. In Industrie 4.0 in Produktion, Automatisierung und Logistik; Springer Fachmedien Wiesbaden: Wiesbaden, Germany, 2014; pp. 603-614. 
74. Lee, J.; Kao, H.-A.; Yang, S. Service Innovation and Smart Analytics for Industry 4.0 and Big Data Environment. Proc. CIRP 2014, 16, 3-8. [CrossRef]

75. Jose, R.; Ramakrishna, S. Materials 4.0: Materials Big Data Enabled Materials Discovery. Appl. Mat. Today. 2018, 10, 127-132. [CrossRef]

76. Buer, S.-V.; Strandhagen, J.O.; Chan, F.T.S. The Link between Industry 4.0 and Lean Manufacturing: Mapping Current Research and Establishing a Research Agenda. Int. J. Produc. Res. 2018, 56, 2924-2940. [CrossRef]

77. Brettel, M.; Friederichsen, N.; Keller, M.; Rosenberg, M. How Virtualization, Decentralization, and Network-Building Change the Manufacturing Landscape: An Industry 4.0 Perspective. Int. J. Mech. Aerospac. Indust. Mechatron. Manuf. Eng. 2014, 8, 37-44.

78. Tay, S.I.; Lee, T.C.; Hamid, N.A.A.; Ahmad, A.N.A. An Overview of Industry 4.0: Definition, Components, and Government Initiatives. J. Adv. Res. Dynamic Control Syst. 2018, 10, 1379-1387.

79. Xu, X. Machine Tool 4.0 for the New Era of Manufacturing. Int. J. Adv. Manuf. Techn. 2017, 92, 1893-1900. [CrossRef]

80. Sipsas, K.; Alexopoulos, K.; Xanthakis, V.; Chryssolouris, G. Collaborative Maintenance in Flow-Line Manufacturing Environments: An Industry 4.0 Approach. Proc. CIRP 2016, 55, 236-241. [CrossRef]

81. Posada, J.; Toro, C.; Barandiaran, I.; Oyarzun, D.; Stricker, D.; de Amicis, R.; Pinto, E.B.; Eisert, P.; Döllner, J.; Vallarino, I. Visual Computing as a Key Enabling Technology for Industrie 4.0 and Industrial Internet. IEEE Comp. Graph Appl. 2015, 35, 26-40. [CrossRef] [PubMed]

82. Hozdic, E. Smart Factory for Industry 4.0: A Review. Int. J. Modern Manuf. Tech. 2015, 7, 28-35.

83. Zhong, R.Y.; Xu, X.; Klotz, E.; Newman, S.T. Intelligent Manufacturing in the Context of Industry 4.0: A Review. J. Eng. 2017, 3, 616-630. [CrossRef]

84. Łobaziewicz, M. Zarządzanie Inteligentnym Przedsiębiorstwem w Dobie Przemystu 4.0; Towarzystwo Naukowe Organizacji i Kierownictwa: Toruń, Poland, 2019.

85. Bahrin, M.A.K.; Othman, M.F.; Azli, N.H.N.; Talib, M.F. Industry 4.0: A Review on Industrial Automation and Robotic. J. Tekno 2016, 78, 137-143. [CrossRef]

86. Vaidya, S.; Ambad, P.; Bhosle, S. Industry 4.0-A Glimpse. Proc. Manuf. 2018, 20, 233-238. [CrossRef]

87. Lee, J.; Bagheri, B.; Kao, H.-A. A Cyber-Physical Systems Architecture for Industry 4.0-Based Manufacturing Systems. Manuf. Lett. 2015, 3, 18-23. [CrossRef]

88. Stock, T.; Seliger, G. Opportunities of Sustainable Manufacturing in Industry 4.0. Proc. CIRP 2016, 40, 536-541. [CrossRef]

89. Schumacher, A.; Erol, S.; Sihn, W. A Maturity Model for Assessing Industry 4.0 Readiness and Maturity of Manufacturing Enterprises. Proc. CIRP 2016, 52, 161-166. [CrossRef]

90. Kumar, K.; Zindani, D.; Davim, J.P. Industry 4.0: Developments towards the Fourth Industrial Revolution; Springer Nature: Singapore, 2019.

91. Pfeiffer, S. Robots, Industry 4.0 and Humans, or Why Assembly Work Is More than Routine Work. Societies 2016, 6, 16. [CrossRef]

92. Wang, S.; Wan, J.; Zhang, D.; Li, D.; Zhang, C. Towards Smart Factory for Industry 4.0: A Self-Organized Multi-Agent System with Big Data Based Feedback and Coordination. Comp. Network 2016, 101, 158-168. [CrossRef]

93. Ardito, L.; Petruzzelli, A.M.; Panniello, U.; Garavelli, A.C. Towards Industry 4.0: Mapping Digital Technologies for Supply Chain Management-Marketing Integration. Business Proc. Manag. J. 2019, 25, 323-346. [CrossRef]

94. Mosterman, P.J.; Zander, J. Industry 4.0 as a Cyber-Physical System Study. Software Syst. Model 2016, 15, 17-29. [CrossRef]

95. Almada-Lobo, F. The Industry 4.0 Revolution and the Future of Manufacturing Execution Systems (MES). J. Innov. Manag. 2015, 3, 16-21. [CrossRef]

96. Lu, Y. Industry 4.0: A Survey on Technologies, Applications and Open Research Issues. J. Indust. Infor. Integrat. 2017, 6, 1-10. [CrossRef]

97. Qin, J.; Liu, Y.; Grosvenor, R. A Categorical Framework of Manufacturing for Industry 4.0 and Beyond. Proc. CIRP 2016, 52, 173-178. [CrossRef]

98. Thoben, K.-D.; Wiesner, S.; Wuest, T. 'Industrie 4.0' and Smart Manufacturing-A Review of Research Issues and Application Examples. Int. J. Automat. Techn. 2017, 11, 4-16. [CrossRef]

99. Peroz, I.; Blankenstein, F.; Lange, K.-P.; Naumann, M. Restoring endodontically treated teeth with post and cores-A review. Quintessence Int. 2005, 36, 737-746.

100. Shutzky-Goldberg, I.; Shutzky, H.; Gorfil, C.; Smidt, A. Restoration of endodontically treated teeth review and treatment recommendations. Int. J. Dent. 2009, 2009, 150251. [CrossRef]

101. Schwartz, R.S.; Robbins, J.W. Post placement and restoration of endodontically treated teeth: A literature review. J. Endodon. 2004, 5, 289-301. [CrossRef] [PubMed]

102. De Oliveira, B.P.; Câmara, A.C.; Aguiar, C.M. Prevalence of endodontic diseases: An epidemiological evaluation in a Brazilian subpopulation. Braz. J. Oral Sci. 2016, 15, 119-123. [CrossRef]

103. Alwadani, M.; Mashyakhy, M.H.; Jali, A.; Hakami, A.O.; Areshi, A.; Daghriri, A.A.; Shaabi, F.I.; Al Moaleem, M.M. Dentists and Dental Intern's Preferences of Root Canal Treatment with Restoration Versus Extraction then Implant-Supported Crown Treatment Plan. Open Dent. J. 2019, 13, 93-100. [CrossRef]

104. Estrela, C.; Holland, R.; Estrela, C.R.; Alencar, A.H.; Sousa-Neto, M.D.; Pécora, J.D. Characterization of successful root canal treatment. Braz. Dent. J. 2014, 25, 3-11. [CrossRef] 
105. Aggarwal, A.; Pandey, V.; Bansal, N. Regenerative Endodontics- Potential Approaches in Revitalizing the Tooth Pulp-A Review Article. J. Adv. Med. Dent. Sci. Res. 2019, 7, 27-32. [CrossRef]

106. Sreedev, C.P.; Karthick, K.; Mathew, S.; Raju, I. Regenerative endodontics: An overview. J. Indian Acad. Dent. Spec. Res. 2017, 4, 18-22. [CrossRef]

107. Nair, P.N.R. On the cause of persistent apical periodontitis: A review. Int. Endod. J. 2006, 34, 249-281. [CrossRef]

108. Malarvizhi, D.; Shuruthi, J.; Anuradha, B.; Subbiya, A. Etiology And Management Of Separation Of Instruments In Endodontics An Overview. Eur. J. Mol. Clin. Med. 2020, 7, 1229-1234.

109. Drabarczyk-Nasińska, M.; Kacprzak, M. Nowoczesne leczenie endodontyczne-materiały i metody wypełniania kanału korzeniowego. Borgis Nowa Stomatol. 2001, 3, 11-14.

110. Siqueira, J.F.; Rocas, I.N.; Lopes, H.P. de Uzeda, M. Coronal leakage of two root canal sealers containing calcium hydroxide after exposure to human saliva. J. Endod. 1999, 25, 14-16. [CrossRef]

111. Hirsch, J.M.; Ahlstrom, U.; Henrikson, P.A.; Peterson, L.E. Periapical surgery. Int. J. Oral Surg. 1979, 8, 173-185. [CrossRef]

112. Sundqvist, G.; Figdor, D.; Persson, S.; Sjörgren, U. Microbiological analysis of teeth with failed endodontic treatment and the outcome of conservative re-treatment. Oral Surg. Oral Med. Oral Pathol. Oral Radiol. Endod. 1998, 85, 86-93. [CrossRef]

113. Carrotte, P. Endodontics: Part 1. The modern concept of root canal treatment. Br. Dent. J. 2004, 197, 181-183. [CrossRef] [PubMed]

114. Karamifar, K.; Tondari, A.; Saghiri, M.A. Endodontic Periapical Lesion: An Overview on the Etiology, Diagnosis and Current Treatment Modalities. Eur. Endod. J. 2020, 2, 54-67. [CrossRef]

115. Grossman, L. Endodontic Practice, 11th ed.; Lea \& Fibiger: Phildelphia, PA, USA, 1988; p. 242.

116. Muliyar, S.; Shameem, K.A.; Thankachan, R.P.; Francis, P.G.; Jayapalan, C.S.; Hafiz, K.A. Microleakage in endodontics. J. Int. Oral Health. 2014, 6, 99-104.

117. Krastl, G.; Allgayer, N.; Lenherr, P.; Filippi, A.; Taneja, P.; Weiger, R. Tooth discoloration induced by endodontic materials: A literature review. Dent. Traumatol. 2013, 29, 2-7. [CrossRef]

118. Teixeira, F.B.; Teixeira, E.C.; Thompson, J.Y.; Trope, M. Fracture resistance of roots endodontically treated with a new resin filling material. J. Am. Dent. Assoc. 2004, 135, 646-652. [CrossRef]

119. Ahmad, P.; Dummer, P.M.H.; Noorani, T.Y.; Asif, J.A. The top 50 most-cited articles published in the International Endodontic Journal. Int. Endod. J. 2019, 52, 803-818. [CrossRef]

120. Raghavendra, S.S.; Jadhav, G.R.; Gathani, K.M.; Kotadia, P. Bioceramics in Endodontics-a review. J. Istanbul Univ. Fac. Dent. 2017, 51, S128-S137. [CrossRef]

121. Parirokh, M.; Torabinejad, M.; Dummer, P.M.H. Mineral trioxide aggregate and other bioactive endodontic cements: An updated overview - part I: Vital pulp therapy. Int. Endod. J. 2018, 51, 177-205. [CrossRef]

122. Torabinejad, M.; Parirokh, M.; Dummer, P.M.H. Mineral trioxide aggregate and other bioactive endodontic cements: An updated overview-part II: Other clinical applications and complications. Int. Endod. J. 2018, 51, 284-317. [CrossRef] [PubMed]

123. Malkondu, Ö.; Karapinar-Kazandağ, M.; Kazazoğlu, E. A review on biodentine, a contemporary dentine replacement and repair material. Biomed. Res. Int. 2014, 2014, 160951. [CrossRef]

124. Debelian, G.; Trope, M. The use of premixed bioceramic materials in endodontics. G. Italia. Endod. 2016, 30, 70-80. [CrossRef]

125. Ekambaram, M.; Yiu, C.K.Y.; Matinlinna, J.P. Bonding of adhesive resin to intraradicular dentine: A review of the literature. Int. J. Adhes. Adhes. 2015, 60, 92-103. [CrossRef]

126. Dental Endodontics Market (Product-Instruments (Endodontic Scalers \& Lasers, Motors, Apex Locators, and Machine Assisted Obturation Systems) and Consumables (Obturation, Shaping and Cleaning, and Access Cavity Preparation); End User: Dental Hospitals, Dental Clinics, and Dental Academic \& Research Institutes)-Global Industry Analysis, Size, Share, Growth, Trends, and Forecast 2017-2025. Dental Endodontics Market Size, Share \& Trend I Industry Analysis Report, 2025. Available online: transparencymarketresearch.com (accessed on 6 April 2021).

127. Endodontic Devices Market Size, Share \& Trends Analysis Report By Type (Instruments, Consumables), By End Use (Hospitals, Clinics, Dental Academic \& Research Institutes), And Segment Forecasts, 2019-2026. Endodontic Devices Market Size \& Share I Industry Report, 2019-2026. Available online: grandviewresearch.com (accessed on 6 April 2021).

128. Dental Consumables Market by Product [Dental Implants (Root Form Dental Implants and Plate Form Dental Implants), Dental Prosthetics (Crowns, Bridges, Dentures, Abutments, Veneers, and Inlays \& Onlays), Endodontics (Endodontic Files, Obturators, and Permanent Endodontic Sealers), Orthodontics (Brackets, Archwires, Anchorage Appliances, and Ligatures), Periodontics (Dental Sutures and Dental Hemostats), Retail Dental Care Essentials (Specialized Dental Pastes, Dental Brushes, Dental Wash Solutions, Whitening Agents, and Dental Floss), and Other Dental Consumables (Dental Splints, Dental Sealants, Dental Burs, Dental Impression Materials, Dental Disposables, Bonding Agents, Patient Bibs, and Aspirator Tubes \& Saliva Ejectors)]-Global Opportunity Analysis and Industry Forecast, 2017-2023. Dental Consumables Market Size, Share and Growth opportunities 2023. Available online: alliedmarketresearch.com (accessed on 6 April 2021).

129. Endodontics Market by Instruments (Scalers, Apex Locator, Motors, Handpiece, Laser), Consumables (Access Cavity Preparation, Endodontic Files, Burs, Drill, Lubricant, Obturation), End User (Clinic, Hospital)-Global Forecast to 2022. Endodontics Market by Consumables \& End User I Global Forecast 2022. Available online: marketsandmarkets.com (accessed on 6 April 2021).

130. Ferreira, C.M.; Silva, J.B.A., Jr.; Monteiro de Paula, R.C.; Andrade Feitosa, J.P.; Negreiros Cortez, D.G.; Zaia, A.A.; de Souza-Filho, F.J. Brazilian gutta-percha points. Part I: Chemical composition and X-ray diffraction analysis. Braz. Oral Res. 2005, 19, 193-197. [CrossRef] [PubMed] 
131. Dobrzańska, J.; Gołombek, K.; Dobrzański, L.B. Polymer materials used in endodontic treatment-in vitro testing. AMSE 2012, 58, 110-115.

132. Dobrzańska, J. Analiza Szczelności Wypełnień Kanałów Korzeniowych. Ph.D. Thesis, Śląski Uniwersytet Medyczny w Katowicach, Zabrze, Poland, 2011.

133. Schilder, H.; Goodman, A.; Winthrop, A. The termomechanical properties of gutta-percha. Determination of phase transition temperatures for gutta-percha, Oral Surg. Oral Med. Oral Pathol. 1974, 38, 109-114. [CrossRef]

134. Ferreira, C.M.; Gurgel-Filho, E.D.; Silva, J.B.A., Jr.; Monteiro de Paula, R.C.; Pessoa Andrade Feitosa, J.; Figueiredo de Almeida Gomes, B.P.; de Souza-Filho, F.J. Brazilian gutta-percha points. Part II: Thermal properties. Braz. Oral Res. 2007, $21,29-34$. [CrossRef]

135. Combe, E.C.; Cohen, B.D.; Cumming, K. Alpha- and beta-forms of gutta-percha in products for root canal filling. Int. Endodon. J. 2001, 34, 447-451. [CrossRef]

136. Tully, J. A Victorian Ecological Disaster: Imperialism, the Telegraph, and Gutta-Percha. J. World Hist. 2009, 20, 559-579. [CrossRef]

137. Schilder, H. Filling root canals in three dimensions. Dent. Clin. North Am. 1967, 32, 723-744. [CrossRef]

138. Buchanan, L.S. The continuous wave of condensation technique: A convergence of conceptual and procedural advances in obturation. Dent. Today 1994, 13, 84-85.

139. Hand, R.E.; Huget, E.F.; Tsakinis, P.J. Effects of a warm gutta-percha technique on the lateral periodontium. Oral Surg. Oral Med. Oral Pathol. 1976, 42, 395-401. [CrossRef]

140. Nahmias, Y.; Mab, T.; Dovgan, J.S. The Thermo Hydraulic Condensation Technique. Oral Health 2001, 91, 11-15.

141. Nahmias, Y.; Serota, K.S.; Watson Jr, W.R. Predictable Endodontic Success: Part II -Microstructural Replication. Available online: http: / / www.ecoweek.ca/issues / PrinterFriendly.asp?aid=1000156065\&RType=\&PC=\&issue=12012003 (accessed on 6 April 2021).

142. Barattolo, R.; Santarcangelo, F. Otturazione del sistema dei canali radicolari con guttaperca termoplasticizzata: Principi, materiali e tecniche. G. Italia. Endod. 2011, 25, 112-124. [CrossRef]

143. Nahmias, Y.; Mab, T.; Dovgan, J.S. La tecnica di condensazione termoidraulica. L'infor. Endod. 2002, 5, $28-33$.

144. Nahmias, Y.; Bery, P. Due radici palatine nei primi molari superiori. L'infor. Endod. 2007, 10, 48-51.

145. Carvalho-Sousa, B.; Almeida-Gomes, F.; Carvalho, P.R.; Maníglia-Ferreira, C.; Gurgel-Filho, E.D.; Albuquerque, D.S. Filling lateral canals: Evaluation of different filling techniques. Eur. J. Dent. 2010, 4, 251-256. [CrossRef] [PubMed]

146. Siqueira, J.F.; Roças, I.N.; Favieri, A.; Abad, E.C.; Castro, A.J.; Gahyva, S.M. Bacterial leakage in coronally unsealed root canals obturated with 3 different techniques. Oral Surg. Oral Med. Oral Pathol. Oral Radiol. Endod. 2000, 90, 647-650. [CrossRef]

147. Limkangwalmongkol, S.; Burtscher, P.; Abbot, P.; Sandler, A.; Bishop, B. A comparative study of the apical leakage of four root canals sealers and laterally condensed gutta percha. J. Endod. 1991, 17, 495-499. [CrossRef]

148. Swanson, K.; Madison, S. An evaluation of coronal microleakage in endodontically treated teeth. Part 1. Time periods. J. Endod. 1987, 13, 56-59. [CrossRef]

149. Friedman, S.; Torneck, C.; Komorowsji, R.; Ouzounian, Z.; Syrtash, P.; Kaufman, A. In vivo model for assessing the functional efficacy of endodontic materials and techniques. J. Endod. 1997, 23, 557-561. [CrossRef]

150. Torabinejad, M.; Ung, B.; Kettering, J. In vitro bacterial penetration of coronally unsealed endodontically treated teeth. J. Endod. 1990, 16, 566-569. [CrossRef]

151. Shipper, G.; Trope, M. In vitro microbial leakage of endodontically treated teeth using new and standard obturation techniques. J Endod 2004, 30, 154-158. [CrossRef] [PubMed]

152. Magura, M.E.; Kafrawy, A.H.; Brown, C.E.; Newton, C.W. Human saliva coronal microleakeage in obturated root canals: An in vitro study. J. Endod. 1991, 17, 324-331. [CrossRef]

153. Oliver, C.; Abbott, P. An in vitro study of apical and coronal micro leakage of laterally condensed gutta-percha with Ketac-Endo and AH-26. Aust. Dent. J. 1998, 43, 262-268. [CrossRef] [PubMed]

154. Madison, S.; Wilcox, L. An evaluation of coronal microleakge in endodontically treated teeth. Part III. In vivo study. J. Endod. 1988, 14, 455-458. [CrossRef]

155. Khayat, A.; Lee, S.J.; Torabinejad, M. Human saliva penetration of coronally unsealed obturated root canals. J. Endod. 1993, 19, 458-461. [CrossRef]

156. Jafari, F.; Jafari, S. Importance and methodologies of endodontic microleakage studies: A systematic review. J. Clin. Exp. Dent. 2017, 9, e812-e819. [CrossRef]

157. Møller, L.; Wenzel, A.; Wegge-Larsen, A.M.; Ding, M.; Væth, M.; Hirsch, E.; Kirkevang, L.-L. Comparison of images from digital intraoral receptors and cone beam computed tomography scanning for detection of voids in root canal fillings: An in vitro study using micro-computed tomography as validation. Oral Surg. Oral Med. Oral Pathol. Oral Radiol. 2013, 115, 810-818. [CrossRef]

158. Imura, N.; Kato, A.S.; Hata, G.I.; Uemura, M.; Toda, T.; Weine, F. A comparison of the relative efficacies of four hand and rotary instrumentation techniques during endodontic retreatment. Int. Endod. J. 2000, 33, 361-366. [CrossRef]

159. Ferreira, J.J.; Rhodes, J.S.; Pitt Ford, T.R. The efficacy of gutta-percha removal using ProFiles. Int. Endod. J. 2001, 34, 267-274. [CrossRef]

160. Li, G.H.; Niu, L.N.; Selem, L.C.; Eid, A.A.; Bergeron, B.E.; Chen, J.H.; Pashley, D.H.; Tay, F.R. Quality of obturation achieved by an endodontic core-carrier system with crosslinked gutta-percha carrier in single-rooted canals. J. Dent. 2014, 42, 1124-1134. [CrossRef] [PubMed] 
161. Donnermeyer, D.; Bürklein, S.; Dammaschke, T.; Schäfer, E. Endodontic sealers based on calcium silicates: A systematic review. Odontol. 2019, 107, 421-436. [CrossRef]

162. Gandolfi, M.G.; Siboni, F.; Prati, C. Properties of a novel polysiloxane-guttapercha calcium silicate-bioglass-containing root canal sealer. Dent. Mater. 2016, 32, e113-e126. [CrossRef] [PubMed]

163. Zoufan, K.; Jiang, J.; Komabayashi, T.; Wang, Y.-H.; Safavi, K.E.; Zhu, Q. Cytotoxicity evaluation of Gutta Flow and Endo Sequence BC sealers. Oral Surg. Oral Med. Oral Pathol. Oral Radiol. Endod. 2011, 112, 657-661. [CrossRef] [PubMed]

164. Zmener, O. Tissue response to a new methacrylate-based root canal sealer: Preliminary observations in the subcutaneous connective tis- sues of rats. J. Endod. 2004, 30, 348-351. [CrossRef]

165. Friedman, S.; Löst, C.; Zarrabian, M.; Trope, M. Evaluation of success and failure after endodontic therapy using a glass ionomer cement sealer. J. Endod. 1995, 21, 384-390. [CrossRef]

166. Lee, K.W.; Williams, M.C.; Camps, J.J.; Pashley, D.H. Adhesion of endodontic sealers to dentin and gutta-percha. J. Endod. 2002, 28, 684-688. [CrossRef]

167. Gatwood, R.S. Endodontic materials. Dent. Clin. North Am. 2007, 15, 695-712. [CrossRef]

168. Shipper, G.; Ørstavik, D.; Teixeira, F.B.; Trope, M. An evaluation of microbial leakage in roots filled with a thermoplastic synthetic polymer-based root canal filling material (Resilon). J. Endod. 2004, 30, 342-347. [CrossRef] [PubMed]

169. Resilon ${ }^{\mathrm{TM}}$ Obturation Material-The New Standard of Care? Available online: https:/ /www.endoexperience.com/ filecabinet/ Clinical\%20Endodontics/Obturation/Resilon/Resilon.Fact.Sheet.pdf (accessed on 1 April 2021).

170. Lipski, M.; Woźniak, K.; Buczkowska-Radlińska, J.; Łagocka, R.; Bochińska, J.; Nowicka, A. Resilon i Epiphany nowy materiał do wypełniania kanałów korzeniowych zębów: Badania wstępne w SEM. Mag. Stomat. 2005, 9, 108-112.

171. Lotfi, M.; Ghasemi, N.; Rahimi, S.; Vosoughhosseini, S.; Saghiri, M.A.; Shahidi, A. Resilon: A comprehensive literature review. J. Dent. Res. Dent. Clin. Dent. Prospects 2013, 7, 119-130. [CrossRef] [PubMed]

172. Pawińska, M.; Kierklo, A.; Marczuk-Kolada, G. New technology in endodontics-the Resilon-Epiphany system for obturation of root canals. Adv. Med. Sci. 2006, 51 (Suppl. 1), 154-157.

173. Pocket Dentistry. Gutta-percha Substitute: Resilon. Available online: https://pocketdentistry.com/33-gutta-percha-substituteresilon/ (accessed on 1 April 2021).

174. Mohammadi, Z.; Jafarzadeh, H.; Shalavi, S.; Bhandi, S.; Kinoshita, J. Resilon: Review of a New Material for Obturation of the Canal. J. Contemp. Dent. Pract. 2015, 16, 407-414. [CrossRef]

175. Barnett, F.; Trope, M. Resilon ${ }^{\mathrm{TM}}$ : A novel material to replace gutta-percha. Contemp. Endod. 2004, 1, 16-19.

176. Hammad, M.; Qualtrough, A.; Silikas, N. Effect of a new obturating material on vertical root fracture resistance of endodontically treated teeth. J. Endod. 2007, 33, 732-736. [CrossRef]

177. Teixeira, F.B.; Teixeira, E.C.N.; Thompson, J.Y.; Leinfelder, K.F.; Trope, M. Dentinal bonding reaches the root canal system. J. Esthet. Restor. Dent. 2004, 16, 348-354. [CrossRef]

178. Shipper, G.; Teixeira, F.B.; Arnold, R.R.; Trope, M. Periapical inflammation after coronal microbial inoculation of dog roots filled with gutta-percha or resilon. J. Endod. 2005, 31, 91-96. [CrossRef] [PubMed]

179. Shrestha, D.; Wei, X.; Wu, W.-C.; Ling, J.-Q. Resilon: A methacrylate resin-based obturation system. J. Dent. Sci. 2010, 5, 47-52. [CrossRef]

180. Resende, L.M.; Rached-Junior, F.J.; Versiani, M.A.; Souza-Gabriel, A.E.; Miranda, C.E.; Silva-Sousa, Y.T.; Sousa Neto, M.D. A comparative study of physicochemical properties of AH Plus, Epiphany, and Epiphany SE root canal sealers. Int. Endod. J. 2009, 42, 785-793. [CrossRef]

181. Rocha, A.W.; de Andrade, C.D.; Leitune, V.C.; Collares, F.M.; Samuel, S.M.; Grecca, F.S.; de Figueiredo, J.A.; dos Santos, R.B. Influence of endodontic irrigants on resin sealer bond strength to radicular dentin. Bull. Tokyo Dent. Coll. 2012, 53, 1-7. [CrossRef] [PubMed]

182. Strange, K.A.; Tawil, P.Z.; Phillips, C.; Walia, H.D.; Fouad, A.F. Long-term Outcomes of Endodontic Treatment Performed with Resilon/Epiphany. J. Endod. 2019, 45, 507-512. [CrossRef]

183. Pawińska, M.; Kierklo, A.; Tokajuk, G.; Sidun, J. New endodontic obturation systems and their interfacial bond strength with intraradicular dentine-ex vivo studies. Adv. Med. Sci. 2011, 56, 327-333. [CrossRef] [PubMed]

184. Kqiku, L.; Miletic, I.; Gruber, H.J.; Anic, I.; Städtler, P. Dichtigkeit von Wurzelkanalfüllungen mit GuttaFlow und Resilon im Vergleich zur lateralen Kondensation. Wien Med. Wochenschr. 2010, 160, 230-234. [CrossRef]

185. Shokouhinejad, N.; Sabeti, M.A.; Hasheminasab, M.; Shafiei, F.; Shamshiri, A.R. Push-out bond strength of Resilon/Epiphany self-etch to intraradicular dentin after retreatment: A preliminary study. J. Endod. 2010, 36, 493-496. [CrossRef]

186. De-Deus, G.; Namen, F.; Galan Jr, J.; Zehnder, M. Soft chelating irrigation protocol optimizes bonding quality of Resilon/Epiphany root fillings. J. Endod. 2008, 34, 703-705. [CrossRef] [PubMed]

187. Üreyen Kaya, B.; Keçeci, A.D.; Orhan, H.; Belli, S. Micropush-out bond strengths of gutta-percha versus thermoplastic synthetic polymer-based systems—an ex vivo study. Int. Endod. J. 2008, 41, 211-218. [CrossRef] [PubMed]

188. Fisher, M.A.; Berzins, D.W.; Bahcall, J.K. An in vitro comparison of bond strength of various obturation materials to root canal dentin using a push-out test design. J. Endod. 2007, 33, 856-858. [CrossRef]

189. Sly, M.M.; Moore, B.K.; Platt, J.A.; Brown, C.E. Push-out bond strength of a new endodontic obturation system (Resilon/Epiphany). J. Endod. 2007, 33, 160-162. [CrossRef] 
190. Dumani, A.; Yoldas, O.; Isci, A.S.; Köksal, F.; Kayar, B.; Polat, E. Disinfection of artificially contaminated Resilon cones with chlorhexidine and sodium hypochlorite at different time exposures. Oral Surg. Oral Med. Oral Pathol. Oral Radiol. Endod. 2007, 103, e82-e85. [CrossRef]

191. Shokouhinejad, N.; Sharifian, M.R.; Jafari, M.; Sabeti, M.A. Push-out bond strength of Resilon/Epiphany self-etch and guttapercha/AH26 after different irrigation protocols. Oral Surg. Oral Med. Oral Pathol. Oral Radiol. Endod. 2010, 110, e88-e92. [CrossRef] [PubMed]

192. Kumar, N.; Aggarwal, V.; Singla, M.; Gupta, R. Effect of various endodontic solutions on punch out strength of Resilon under cyclic loading. J. Conserv. Dent. 2011, 14, 366-369. [CrossRef] [PubMed]

193. Tay, F.R.; Loushine, R.J.; Weller, R.N.; Kimbrough, W.F.; Pashley, D.H.; Mak, Y.F.; Lai, C.N.; Raina, R.; Williams, M.C. Ultrastructural evaluation of the apical seal in roots filled with a polycaprolactone-based root canal filling material. J. Endod. 2005, 31, 514-519. [CrossRef] [PubMed]

194. Shin, S.J.; Jee, S.W.; Song, J.S.; Jung, I.Y.; Cha, J.H.; Kim, E. Comparison of regrowth of Enterococcus faecalis in dentinal tubules after sealing with gutta-percha or Resilon. J. Endod. 2008, 34, 445-448. [CrossRef] [PubMed]

195. Jack, R.M.; Goodell, G.G. In vitro comparison of coronal microleakage between Resilon alone and gutta-percha with a glass ionomer intraorifice barrier using a fluid filtration model. J. Endod. 2008, 34, 718-720. [CrossRef]

196. Santos, J.; Tjäderhane, L.; Ferraz, C.; Zaia, A.; Alves, M.; De Goes, M.; Carrilho, M. Long-term sealing ability of resin-based root canal fillings. Int. Endod. J. 2010, 43, 455-460. [CrossRef]

197. Shemesh, H.; Wu, M.K.; Wesselink, P.R. Leakage along the apical root fillings with and without smear layer using two different leakage models: A two month longitudinal ex vivo study. Int. Endod. J. 2006, 39, 968-976. [CrossRef]

198. De Bruyne, M.A.; De Moor, R.J. Long-term sealing ability of Resilon apical root-end fillings. Int. Endod. J. 2009, 42, 884-892. [CrossRef]

199. Deus, G.A.D.; Fábio, M.; Rocha, L.A.C.M.; Gurgel-Filho, E.D.; Maniglia, C.F.; Coutinho-Filho, T. Analysis of the film thickness of a root canal sealer following three obturation techniques. Pesqui Odontol. Bras. 2003, 17, 119-125. [CrossRef]

200. Paqué, F.; Sirtes, G. Apical sealing ability of Resilon/Epiphany versus gutta-percha/AH Plus: Immediate and 16 month leakage. Int. Endod. J. 2007, 40, 722-729. [CrossRef] [PubMed]

201. Pasqualini, D.; Scotti, N.; Mollo, L.; Berutti, E.; Angelini, E.; Migliaretti, G.; Cuffini, A.; Adlerstein, D. Microbial leakage of Gutta-Percha and Resilon root canal filling material: A comparative study using a new homogeneous assay for sequence detection. J. Biomater. Appl. 2008, 22, 337-352. [CrossRef] [PubMed]

202. Shemesh, H.; Souza, E.M.; Wu, M.K.; Wesselink, P.R. Glucose reactivity with filling materials as a limitation for using the glucose leakage model. Int. Endod. J. 2008, 41, 869-872. [CrossRef]

203. Kokorikos, I.; Kolokouris, I.; Economides, N.; Gogos, C.; Helvatjoglu-Antoniades, M. Long-term evaluation of the sealing ability of two root canal sealers in combination with self-etching bonding agents. J. Adhes. Dent. 2009, 11, 239-246. [PubMed]

204. Onay, E.O.; Ungor, M.; Orucoglu, H. An in vitro evaluation of the apical sealing ability of a new resin based root canal obturation system. J. Endod. 2006, 32, 976-978. [CrossRef] [PubMed]

205. Hirai, V.H.; da Silva Neto, U.X.; Westphalen, V.P.D.; Perin, C.P.; Carneiro, E.; Fariniuk, L.F. Comparative analysis of leakage in root canal filling performed with gutta-percha and Resilon cones with AH Plus and Epiphany sealers. Oral Surg. Oral Med. Oral Pathol. Oral Radiol. Endod. 2010, 109, 131-135. [CrossRef]

206. Saleh, I.M.; Ruyter, I.E.; Haapasalo, M.; Ørstavik, D. Bacterial penetration along different root canal filling materials in the presence or absence of smear layer. Int. Endod. J. 2008, 41, 32-40. [CrossRef]

207. De-Deus, G.; Namen, F; Galan, J. Reduced long-term sealing ability of adhesive root fillings after water-storage stress. J. Endod. 2008, 34, 322-325. [CrossRef]

208. Pandey, P.; Aggarwal, H.; Tikku, A.P.; Singh, A.; Bains, R.; Mishra, S. Comparative evaluation of sealing ability of gutta percha and resilon as root canal filling materials- a systematic review. J Oral Biol Craniofac Res 2020, 10, 220-226. [CrossRef]

209. Barborka, B.J.; Woodmansey, K.F.; Glickman, G.N.; Schneiderman, E.; He, J. Long-term Clinical Outcome of Teeth Obturated with Resilon. J. Endod. 2017, 43, 556-560. [CrossRef]

210. Lyons, W.W.; Hartwell, G.R.; Stewart, J.T.; Reavley, B.; Appelstein, C.; Lafkowitz, S. Comparison of coronal bacterial leakage between immediate versus delayed post-space preparations in root canals filled with Resilon/Epiphany. Int. Endod. J. 2009, 42, 203-207. [CrossRef] [PubMed]

211. Silveira, F.F.; Soares, J.A.; Nunes, E.; Mordente, V.L. Negative influence of continuous wave technique on apical sealing of the root canal system with Resilon. J. Oral Sci. 2007, 49, 121-128. [CrossRef] [PubMed]

212. De-Deus, G.; Audi, C.; Murad, C.; Fidel, S.; Fidel, R.A. Sealing ability of oval-shaped canals filled using the System B heat source with either gutta-percha or Resilon: An ex vivo study using a polymicrobial leakage model. Oral Surg. Oral Med. Oral Pathol. Oral Radiol. Endod. 2007, 104, 114-119. [CrossRef] [PubMed]

213. Baumgartner, G.; Zehnder, M.; Paqué, F. Enterococcus faecalis type strain leakage through root canals filled with Gutta-Percha/AH plus or Resilon/Epiphany. J. Endod. 2007, 33, 45-47. [CrossRef] [PubMed]

214. Hollanda, A.C.B.; Estrela, C.R.; Decurcio, D.A.; Silva, J.A.; Estrela, C. Sealing ability of three commercial resin-based endodontic sealers. Gen. Dent. 2009, 57, 368-373.

215. Kocak, M.M.; Er, O.; Saglam, B.C.; Yaman, S. Apical leakage of epiphany root canal sealer combined with different master cones. Eur. J. Dent. 2008, 2, 91-95. [CrossRef] 
216. Bodrumlu, E.; Tunga, U. The apical sealing ability of a new root canal filling material. Am. J. Dent. 2007, 20, 295-298.

217. Raina, R.; Loushine, R.J.; Weller, R.N.; Tay, F.R.; Pashley, D.H. Evaluation of the quality of the apical seal in Resilon/ Epiphany and gutta-percha/AH Plus-filled root canals by using a fluid filtration approach. J. Endod. 2007, 33, 944-947. [CrossRef]

218. Pitout, E.; Oberholzer, T.G.; Blignaut, E.; Molepo, J. Coronal leakage of teeth root-filled with gutta-percha or Resilon root canal filling material. J. Endod. 2006, 32, 610-615. [CrossRef]

219. Fransen, J.N.; He, J.; Glickman, G.N.; Rios, A.; Shulman, J.D.; Honeyman, A. Comparative assessment of ActiV GP/glass ionomer sealer, Resilon/Epiphany, and gutta-percha/AH plus obturation: A bacterial leakage study. J. Endod. 2008, 34, 725-727. [CrossRef]

220. Shokouhinejad, N.; Sharifian, M.R.; Aligholi, M.; Assadian, H.; Tabor, R.K.; Nekoofar, M.H. The sealing ability of Resilon and gutta-percha following different smear layer removal methods: An ex vivo study. Oral Surg. Oral Med. Oral Pathol. Oral Radiol. Endod. 2010, 110, 45-49. [CrossRef]

221. Kangarlou, A.; Dianat, O.; Esfahrood, Z.R.; Asharaf, H.; Zandi, B.; Eslami, G. Bacterial leakage of GuttaFlow-filled root canals compared with Resilon/Epiphany and Gutta-percha/AH26-filled root canals. Aust. Endod. J. 2012, 38, 10-13. [CrossRef]

222. Biggs, S.C.; Knowles, K.I.; Ibarrola, J.L.; Pashley, D.H. An in vitro assessment of the sealing ability of Resilon/Epiphany using a fluid filtration. J. Endod. 2006, 32, 759-761. [CrossRef]

223. Karapınar-Kazandağ, M.; Tanalp, J.; Bayrak, Ö.F.; Sunay, H.; Bayirh, G. Microleakage of various root filling systems by glucose filtration analysis. Oral Surg. Oral Med. Oral Pathol. Oral Radiol. Endod. 2010, 109, e96-e102. [CrossRef]

224. Oddoni, P.G.; Mello, I.; Coil, J.M.; Antoniazzi, J.H. Coronal and apical leakage analysis of two different root canal obturation systems. Braz. Oral Res. 2008, 22, 211-215. [CrossRef]

225. De Almeida-Gomes, F.; Maniglia-Ferreira, C.; de Morais Vitoriano, M.; Carvalho-Sousa, B.; Guimaraes, N.L.; dos Santos, R.A.; Gurgel-Filho, E.D.; Rocha, M.M. Ex vivo evaluation of coronal and apical microbial leakage of root canal-filled with gutta-percha or Resilon/Epiphany root canal filling material. Indian J. Dent. Res. 2010, 21, 98-103. [CrossRef]

226. Üreyen Kaya, B.; Keçeci, A.D.; Belli, S. Evaluation of the sealing ability of gutta-percha and thermoplastic synthetic polymer-based systems along the root canals through the glucose penetration model. Oral Surg. Oral Med. Oral Pathol. Oral Radiol. Endod. 2007, 104, E66-E73. [CrossRef]

227. Dultra, F.; Barroso, J.M.; Carrasco, L.D.; Capelli, A.; Guerisoli, D.M.; Pécora, J.D. Evaluation of apical microleakage of teeth sealed with four different canal sealers. J. Appl. Oral Sci. 2006, 14, 341-345. [CrossRef] [PubMed]

228. Muñoz, H.R.; Saravia-Lemus, G.A.; Florián, W.E.; Lainfiesta, J.F. Microbial leakage of Enterococcus faecalis after post space preparation in teeth filled in vivo with RealSeal versus gutta-percha. J. Endod. 2007, 33, 674-675. [CrossRef] [PubMed]

229. Tanomaru-Filho, M.; Sant'anna-Junior, A.; Bosso, R.; Guerreiro-Tanomaru, J.M. Effectiveness of gutta-percha and Resilon in filling lateral root canals using the Obtura II system. Braz. Oral Res. 2011, 25, 205-209. [CrossRef] [PubMed]

230. Bodrumlu, E.; Tunga, U. Coronal sealing ability of a new root canal filling material. J. Can. Dent. Assoc. 2007, 73, 623. [PubMed]

231. Sharifian, M.R.; Shokouhinejad, N.; Aligholi, M.; Jafari, Z. Effect of chlorhexidine on coronal microleakage from root canals obturated with Resilon/Epiphany Self-Etch. J. Oral Sci. 2010, 52, 83-87. [CrossRef] [PubMed]

232. Bodrumlu, E.; Tunga, U. Apical leakage of Resilon obturation material. J. Contemp. Dent. Pract. 2006, 7, 45-52. [CrossRef] [PubMed]

233. Verissimo, D.M.; do Vale, M.S.; Monteiro, A.J. Comparison of apical leakage between canals filled with gutta-percha/AH-plus and Resilon/Epiphany System, when submitted to two filling techniques. J. Endod. 2007, 33, 291-294. [CrossRef]

234. Moura-Netto, C.; Pinto, T.; Davidowicz, H.; de Moura, A.A.M. Apical leakage of three resin-based endodontic sealers after 810-nm-diode laser irradiation. Photomed. Laser Surg. 2009, 27, 891-894. [CrossRef]

235. Wedding, J.R.; Brown, C.E.; Legan, J.J.; Moore, B.K.; Vail, M.M. An in vitro comparison of micro leakage between Resilon and gutta-percha with a fluid filtration model. J. Endod. 2007, 33, 1447-1449. [CrossRef]

236. Ishimura, H.; Yoshioka, T.; Suda, H. Sealing ability of new adhesive root canal filling materials measured by new dye penetration method. Dent. Mater. J. 2007, 26, 290-295. [CrossRef]

237. Nawal, R.R.; Parande, M.; Sehgal, R.; Rao, N.R.; Naik, A. A comparative evaluation of 3 root canal filling systems. Oral Surg. Oral Med. Oral Pathol. Oral Radiol. Endod. 2011, 111, 387-393. [CrossRef]

238. Punia, S.K.; Nadig, P.; Punia, V. An in vitro assessment of apical microleakage in root canals obturated with guttaflow, Resilon, thermafil and lateral condensation: A stereomicroscopic study. J. Conserv. Dent. 2011, 14, 173-177. [CrossRef] [PubMed]

239. Tunga, U.; Bodrumlu, E. Assessment of the sealing ability of a new root canal obturation material. J. Endod. 2006, 32, 876-878. [CrossRef] [PubMed]

240. Shashidhar, C.; Shivanna, V.; Shivamurthy, G.; Shashidhar, J. The comparison of microbial leakage in roots filled with resilon and gutta-percha: An in vitro study. J. Conserv. Dent. 2011, 14, 21-27. [CrossRef]

241. Sagsen, B.; Er, O.; Kahraman, Y.; Orucoglu, H. Evaluation of micro leakage of roots filled with different techniques with a computerized fluid filtration technique. J. Endod. 2006, 32, 1168-1170. [CrossRef] [PubMed]

242. Kqiku, L.; Städtler, P.; Gruber, H.J.; Baraba, A.; Anic, I.; Miletic, I. Active versus passive microleakage of Resilon/Epiphany and gutta-percha/AH Plus. Aust. Endod. J. 2011, 37, 141-146. [CrossRef] [PubMed]

243. Aptekar, A.; Ginnan, K. Comparative analysis of microleakage and seal for two obturation materials: Resilon/Epiphany and gutta-percha. J. Can. Dent. Assoc. 2006, 72, 245. [PubMed]

244. Stratton, R.K.; Apicella, M.J.; Mines, P. A fluid filtration comparison of gutta-percha versus Resilon, a new soft resin endodontic obturation system. J. Endod. 2006, 32, 642-645. [CrossRef] 
245. Kurtzman, G.M. Resilon Update. Inside Dent. 2007, 3, 1-5.

246. Mohammadi, Z.; Khademi, A. An evaluation of the sealing ability of MTA and Resilon: A bacterial leakage study. Iran Endod. J. 2007, 2, 43-46. [PubMed]

247. Maltezos, C.; Glickman, G.N.; Ezzo, P.; He, J. Comparison of the sealing of Resilon, Pro Root MTA, and Super-EBA as root-end filling materials: A bacterial leakage study. J. Endod. 2006, 32, 324-327. [CrossRef] [PubMed]

248. Nagas, E.; Cehreli, Z.C.; Durmaz, V.; Vallittu, P.K.; Lassila, L.V. Regional push-out bond strength and coronal microleakage of Resilon after different light-curing methods. J. Endod. 2007, 33, 1464-1468. [CrossRef] [PubMed]

249. Williamson, A.E.; Marker, K.L.; Drake, D.R.; Dawson, D.V.; Walton, R.E. Resin-based versus gutta-percha-based root canal obturation: Influence on bacterial leakage in an in vitro model system. Oral Surg. Oral Med. Oral Pathol. Oral Radiol. Endod. 2009, 108, 292-296. [CrossRef]

250. Hanada, T.; Quevedo, C.G.; Okitsu, M.; Yoshioka, T.; Iwasaki, N.; Takahashi, H.; Suda, H. Effects of new adhesive resin root canal filling materials on vertical root fractures. Aust. Endod. J. 2010, 36, 19-23. [CrossRef] [PubMed]

251. Ulusoy, Ö.İA.; Nayır, Y.; Darendeliler-Yaman, S. Effect of different root canal sealers on fracture strength of simulated immature roots. Oral Surg. Oral Med. Oral Pathol. Oral Radiol. Endod. 2011, 112, 544-547. [CrossRef] [PubMed]

252. Shashidhar, J.; Shashidhar, C. Gutta percha verses resilon: An in vitro comparison of fracture resistance in endodontically treated teeth. J Indian Soc Pedod Prev Dent 2014, 32, 53-57. [CrossRef]

253. Baba, S.M.; Grover, S.I.; Tyagi, V. Fracture resistance of teeth obturated with gutta percha and Resilon: An in vitro study. J. Conserv. Dent. 2010, 13, 61-64. [CrossRef] [PubMed]

254. De Temiño Morante, P.R. ¿Es el Resilon el nuevo Material de Obturación Endodóntica? Available online: https:/ / gacetadental. com/2011/10/es-el-resilon-el-nuevo-material-de-obturacin-endodntica-25262/ (accessed on 1 April 2021).

255. Hemalatha, H.; Sandeep, M.; Kulkarni, S.; Yakub, S.S. Evaluation of fracture resistance in simulated immature teeth using Resilon and Ribbond as root reinforcements—an in vitro study. Dent. Traumatol. 2009, 25, 433-438. [CrossRef] [PubMed]

256. Sagsen, B.; Er, O.; Kahraman, Y.; Akdogan, G. Resistance to fracture of roots filled with three different techniques. Int. Endod. J. 2007, 40, 31-35. [CrossRef]

257. Grande, N.M.; Plotino, G.; Lavorgna, L.; Ioppolo, P.; Bedini, R.; Pameijer, C.H.; Somma, F. Influence of different root canal-filling materials on the mechanical properties of root canal dentin. J. Endod. 2007, 33, 859-863. [CrossRef]

258. Ribeiro, F.C.; Souza-Gabriel, A.E.; Marchesan, M.A.; Alfredo, E.; Silva-Sousa, Y.T.; Sousa-Neto, M.D. Influence of different endodontic filling materials on root fracture susceptibility. J. Dent. 2008, 36, 69-73. [CrossRef]

259. Economides, N.; Koulaouzidou, E.A.; Gogos, C.; Kolokouris, I.; Beltes, P.; Antoniades, D. Comparative study of the cytotoxic effect of Resilon against two cell lines. Braz. Dent. J. 2008, 19, 291-295. [CrossRef]

260. Donadio, M.; Jiang, J.; He, J.; Wang, Y.H.; Safavi, K.E.; Zhu, Q. Cytotoxicity evaluation of Activ GP and Resilon sealers in vitro. Oral Surg. Oral Med. Oral Pathol. Oral Radiol. Endod. 2009, 107, e74-e78. [CrossRef]

261. Susini, G.; About, I.; Tran-Hung, L.; Camps, J. Cytotoxicity of Epiphany and Resilon with a root model. Int. Endod. J. 2006, 39, 940-944. [CrossRef]

262. Leonardo, M.R.; Barnett, F.; Debelian, G.J.; de Pontes Lima, R.K.; da Silva, L.A.B. Root canal adhesive filling in dogs' teeth with or without coronal restoration: A histopathological evaluation. J. Endod. 2007, 33, 1299-1303. [CrossRef]

263. Bodrumlu, E.; Muglali, M.; Sumer, M.; Guvenc, T. The response of subcutaneous connective tissue to a new endodontic filling material. J. Biomed. Mater. Res. B Appl. Biomater. 2008, 84, 463-467. [CrossRef] [PubMed]

264. Merdad, K.; Pascon, A.E.; Kulkarni, G.; Santerre, P.; Friedman, S. Short-term cytotoxicity assessment of components of the epiphany resin-percha obturating system by indirect and direct contact millipore filter assays. J. Endod. 2007, 33, 24-27. [CrossRef]

265. Onay, E.O.; Ungor, M.; Ozdemir, B.H. In vivo evaluation of the biocompatibility of a new resin-based obturation system. Oral Surg. Oral Med. Oral Pathol. Oral Radiol. Endod. 2007, 104, e60-e66. [CrossRef]

266. Bodrumlu, E.; Alaçamm, T. The antimicrobial and antifungal activity of a root canal core material. J. Am. Dent. Assoc. 2007, 138, 1228-1232. [CrossRef] [PubMed]

267. Gomes, B.P.; Berber, V.B.; Montagner, F.; Sena, N.T.; Zaia, A.A.; Ferraz, C.C.; Souza-Filho, F.J. Residual effects and surface alterations in disinfected gutta-percha and Resilon cones. J. Endod. 2007, 33, 948-951. [CrossRef] [PubMed]

268. Cunha, R.S.; De Martin, A.S.; Barros, P.P.; da Silva, F.M.; de Castilho Jacinto, R.; da Silveira Bueno, C.E. In vitro evaluation of the cleansing working time and analysis of the amount of gutta-percha or Resilon remnants in the root canal walls after instrumentation for endodontic retreatment. J. Endod. 2007, 33, 1426-1428. [CrossRef]

269. Fenoul, G.; Meless, G.D.; Pérez, F. The efficacy of R-Endo rotary NiTi and stainless steel hand instruments to remove gutta-percha and Resilon. Int. Endod. J. 2010, 43, 135-141. [CrossRef]

270. Schirrmeister, J.F.; Meyer, K.M.; Hermanns, P.; Altenburger, M.J.; Wrbas, K.T. Effectiveness of hand and rotary instrumentation for removing a new synthetic polymer-based root canal obturation material (Epiphany) during retreatment. Int. Endod. J. 2006, 39, 150-156. [CrossRef]

271. Marfisi, K.; Mercade, M.; Plotino, G.; Duran-Sindreu, F.; Bueno, R.; Roig, M. Efficacy of three different rotary files to remove gutta-percha and resilon from root canals. Int. Endod. J. 2010, 43, 1022-1028. [CrossRef]

272. Zarei, M.; Shahrami, F.; Vatanpour, M. Comparison between gutta-percha and Resilon retreatment. J. Oral Sci. 2009, 51, 181-185. [CrossRef] 
273. Somma, F.; Cammarota, G.; Plotino, G.; Grande, N.M.; Pameijer, C.H. The effectiveness of manual and mechanical instrumentation for the retreatment of three different root canal filling materials. J. Endod. 2008, 34, 466-469. [CrossRef]

274. Taşdemir, T.; Yildirim, T.; Celik, D. Comparative study of removal of current endodontic fillings. J. Endod. 2008, 34, 326-329. [CrossRef]

275. Iizuka, N.; Takenaka, S.; Shigetani, Y.; Okiji, T. Removal of resin-based root canal filling materials with K3 rotary instruments: Relative efficacy for different combinations of filling materials. Dent. Mater. J. 2008, 27, 75-80. [CrossRef]

276. Hassanloo, A.; Watson, P.; Finer, Y.; Friedman, S. Retreatment efficacy of the Epiphany soft resin obturation system. Int. Endod. J. 2007, 40, 633-643. [CrossRef]

277. Tanomaru-Filho, M.; Orlando, T.A.; Bortoluzzi, E.A.; Silva, G.F.; Tanomaru, J.M. Solvent capacity of different substances on gutta-percha and Resilon. Braz. Dent. J. 2010, 21, 46-49. [CrossRef]

278. Faria-Júnior, N.B.; Loiola, L.E.; Guerreiro-Tanomaru, J.M.; Berbert, F.L.; Tanomaru-Filho, M. Effectiveness of three solvents and two associations of solvents on gutta-percha and Resilon. Braz. Dent. J. 2011, 22, 41-44. [CrossRef] [PubMed]

279. Bodrumlu, E.; Uzun, O.; Topuz, O.; Semiz, M. Efficacy of three techniques in removing root canal filling material. J. Can. Dent. Assoc. 2008, 74, 721. [PubMed]

280. Ezzie, E.; Fleury, A.; Solomon, E.; Spears, R.; He, J. Efficacy of retreatment techniques for a resin based root canal obturation material. J. Endod. 2006, 32, 341-344. [CrossRef]

281. Ring, J.; Murray, P.E.; Namerow, K.N.; Moldauer, B.I.; Garcia-Godoy, F. Removing root canal obturation materials: A comparison of rotary file systems and re-treatment agents. J. Am. Dent. Assoc. 2009, 140, 680-688. [CrossRef] [PubMed]

282. De Oliveira, D.P.; Barbizam, J.V.; Trope, M.; Teixeira, F.B. Comparison between gutta-percha and Resilon removal using two different techniques in endodontic retreatment. J. Endod. 2006, 32, 362-364. [CrossRef]

283. Azar, M.; Khojastehpour, L.; Iranpour, N. A comparison of the effectiveness of chloroform in dissolving Resilon and gutta-percha. J. Dent. (Tehran) 2011, 8, 19-24.

284. Shanahan, D.J.; Duncan, H.F. Root canal filling using Resilon: A review. Br. Dent. J. 2011, 211, 81-88. [CrossRef]

285. Steinke, H. Der Hippokratische Eid: Ein schwieriges Erbe. Horiz. Med. Schweiz. Ärztezeitung Bull. Médecins Suisses Boll. Med. Svizz. 2016, 97, 1699-1701.

286. Dobrzańska, J.; Dobrzański, L.B.; Gołombek, K.; Dobrzański, L.A.; Dobrzańska-Danikiewicz, A.D. Results of in vitro experimental research assessing the tightness of filling materials with the pulp of extracted human teeth depending on the obturation techniques during endodontic treatment. Processes. (prepared for printing).

287. Dobrzański, L.A.; Dobrzański, L.B.; Dobrzańska-Danikiewicz, A.D. Manufacturing technologies thick-layer coatings on various substrates and manufacturing gradient materials using powders of metals, their alloys and ceramics. JAMME 2020, 99, 14-41. [CrossRef]

288. Dobrzańska-Danikiewicz, A.D.; Dobrzański, L.A.; Szindler, M.; Achtelik-Franczak, A.; Dobrzański, L.B. Obróbka powierzchni materiałów mikroporowatych wytworzonych metodą selektywnego spiekania laserowego w celu uefektywnienia proliferacji żywych komórek. In Metalowe Materiały Mikroporowate i Lite do Zastosowań Medycznych i Stomatologicznych; Dobrzański, L.A., Dobrzańska-Danikiewicz, A.D., Eds.; Open Access Library VII(1); International OCSCO World Press: Gliwice, Poland, 2017; pp. 289-375.

289. Dobrzańska-Danikiewicz, A. The methodological fundaments of development state analysis of surface engineering technologies. JAMME 2010, 40, 203-210.

290. Dobrzańska-Danikiewicz, A.D.; Hajduczek, E.; Polok-Rubiniec, M.; Przybył, M.; Adamaszek, K. Evaluation of selected steel thermochemical treatment technologies using foresight methods. JAMME 2011, 46, 115-146.

291. Dobrzańska-Danikiewicz, A.D. The development perspectives of Physical Vapour Deposition technologies. JAMME 2012, 54, 103-109.

292. Dobrzańska-Danikiewicz, A.D. Metodologia Komputerowo Zintegrowanego Prognozowania Rozwoju Inżynierii Powierzchni Materiałów; Dobrzański, L.A., Ed.; In Open Access Library 1(7); International OCSCO World Press: Gliwice, Poland, $2012 ;$ pp. 1-289.

293. Dobrzańska-Danikiewicz, A.D. Księga Technologii Krytycznych Kształtowania Struktury i Własności Powierzchni Materiałów Inżynierskich; Dobrzański, L.A., Ed.; In Open Access Library 8(26); International OCSCO World Press: Gliwice, Poland, 2013; pp. 1-823.

294. Dobrzańska-Danikiewicz, A.D. (Ed.) Materials Surface Engineering Development Trends; Open Access Library 6; International OCSCO World Press: Gliwice, Poland, 2011; pp. 1-594.

295. Dobrzańska-Danikiewicz, A.D.; Dobrzański, L.A.; Sękala, A. Results of Technology Foresight in the Surface Engineering Area. AMM 2014, 657, 916-920. [CrossRef]

296. Dobrzańska-Danikiewicz, A.D.; Dobrzański, L.A.; Mazurkiewicz, J.; Tomiczek, B.; Reimann, Ł. E-transfer of materials surface engineering e-foresight results. AMSE 2011, 52, 87-100.

297. Dobrzańska-Danikiewicz, A.D.; Tański, T.; Malara, S.; Domagała-Dubiel, J. Technology Foresight Results Concerning Laser Surface Treatment of Casting Magnesium Alloys. In New Features on Magnesium Alloys; Monteiro, W.A., Ed.; IntechOpen: Rijeka, Croatia, 2012; pp. 1-30. [CrossRef]

298. Dobrzańska-Danikiewicz, A.D. Foresight of Material Surface Engineering as a Tool Building a Knowledge-Based Economy. MSF 2012, 706-709, 2511-2516. [CrossRef] 
299. Dobrzański, L.A. (Ed.) 1st Workshop on Foresight of Surface Properties Formation Leading Technologies of Engineering Materials and Biomaterials; International OCSCO World Press: Gliwice, Poland, 2009; pp. 1-272.

300. Dobrzański, L.A. (Ed.) 2nd Workshop on Foresight of Surface Properties Formation Leading Technologies of Engineering Materials and Biomaterials; International OCSCO World Press: Gliwice, Poland, 2009; pp. 1-324.

301. Dobrzański, L.A.; Dobrzańska-Danikiewicz, A.D. (Eds.) 3rd Workshop on Foresight of Surface Properties Formation Leading Technologies of Engineering Materials and Biomaterials; Raport z realizacji zadania 2. "Analiza Istniejacej Sytuacji w Zakresie Rozwoju Technologii oraz Uwarunkowań Społeczno-Gospodarczych w Odniesieniu do Przedmioty Foresightu pt. FORSURF-Foresight Wiodacych Technologii Kształtowania Własności Powierzchni Materiałów Inżynierskich i Biomedycznych"; International OCSCO World Press: Gliwice, Poland, 2010; pp. 1-184.

302. Dobrzański, L.A.; Achtelik-Franczak, A. Struktura i własności tytanowych szkieletowych materiałów mikroporowatych wytworzonych metodą selektywnego spiekania laserowego do zastosowań w implantologii oraz medycynie regeneracyjnej. In Metalowe Materiały Mikroporowate i Lite do Zastosowań Medycznych i Stomatologicznych; Dobrzański, L.A., Dobrzańska-Danikiewicz, A.D., Eds.; Open Access Library VII(1); International OCSCO World Press: Gliwice, Poland, 2017; pp. 186-244.

303. Dobrzański, L.A. Effect of heat and surface treatment on the structure and properties of the Mg-Al-Zn-Mn casting alloys. In Magnesium and Its Alloys; Dobrzański, L.A., Totten, G.E., Bamberger, M., Eds.; CRC Press: Boca Raton, FL, USA, $2019 ;$ pp. 91-202.

304. Dobrzański, L.A.; Dobrzańska-Danikiewicz, A.D. Perspektywy i trendy rozwojowe inżynierii powierzchni materiałów. In Inżynieria Powierzchni Materiałów: Kompendium Wiedzy i Podręcznik Akademicki; Dobrzański, L.A., Ed.; Open Access Library VIII(1); International OCSCO World Press: Gliwice, Poland, 2018; pp. 89-157.

305. Dobrzański, L.A.; Nieradka-Buczek, B. Transparent conductive nanocomposite layers with polymer matrix and silver nanowires reinforcement. AMSE 2018, 93, 59-84. [CrossRef]

306. Dobrzański, L.A.; Dobrzańska-Danikiewicz, A.D.; Czuba, Z.P.; Dobrzański, L.B.; Achtelik-Franczak, A.; Malara, P.; Szindler, M.; Kroll, L. Metallic skeletons as reinforcement of new composite materials applied in orthopaedics and dentistry. AMSE 2018, 92, 53-85. [CrossRef]

307. Dobrzański, L.A.; Dobrzański, L.B.; Dobrzańska-Danikiewicz, A.D.; Dobrzańska, J.; Rudziarczyk, K.; Achtelik-Franczak, A. Non-Antagonistic Contradictoriness of the Progress of Advanced Digitized Production with SARS-CoV-2 Virus Transmission in the Area of Dental Engineering. Processes 2020, 8, 1097. [CrossRef]

308. Dobrzański, L.A.; Dobrzańska-Danikiewicz, A.; Achtelik-Franczak, A. The structure and properties of aluminium alloys matrix composite materials with reinforcement made of titanium skeletons. AMSE 2016, 80, 16-30. [CrossRef]

309. Dobrzański, L.A.; Prokopiuk vel Prokopowicz, M. The influence of reduced graphene oxide on the structure of the electrodes and the properties of dye-sensitized solar cells. AMSE 2016, 77, 12-30. [CrossRef]

310. Dobrzański, L.A.; Hudecki, A.; Chladek, G.; Król, W.; Mertas, A. Biodegradable and antimicrobial polycaprolactone nanofibers with and without silver precipitates. AMSE 2015, 76, 5-26.

311. Dobrzański, L.A.; Hudecki, A. Structure, geometrical characteristics and properties of biodegradable micro- and polycaprolactone nanofibers. AMSE 2014, 70, 5-13.

312. Dobrzański, L.A.; Pawlyta, M.; Hudecki, A. Conceptual study on a new generation of the high-innovative advanced porous and composite nanostructural functional materials with nanofibers. JAMME 2011, 49, 550-565.

313. Dobrzańska-Danikiewicz, A.D.; Żmudzki, J. Development trends of mucous-borne dentures in the aspect of elastomers applications. AMSE 2012, 55, 5-13.

314. Dobrzański, L.B. Struktura i Własności Materiałów Inżynierskich na Uzupełnienia Protetyczne Układu Stomatognatycznego Wytwarzane Metodami Przyrostowymi i Ubytkowymi. Ph.D. Thesis, Akademia Górniczo-Hutnicza im. Stanisława Staszica w Krakowie, Kraków, Poland, 2017.

315. Rudziarczyk, K. Modelowanie Stanu Naprężeń w Wybranych Rodzajach Implantów Stomatologicznych Oraz w Otaczającej je Tkance Kostnej. Master's Thesis, Politechnika Śląska, Gliwice, Poland, 2020. (manuscript not punlished).

316. Berliński, M.; Suprvisory guidance Dobrzański, L.A. Modelowanie Zależności między Warunkami Wytapiania w Wielkim Piecu i Składem Chemicznym Surówki z Wykorzystaniem Sieci Neuronowych. Ph.D. Thesis, Politechnika Śląska, Gliwice, Poland, 2018.

317. Nieradka-Buczek, B.; Suprvisory Guidance Dobrzański, L.A. Zastosowanie Nanodrutów Srebra jako Wzmocnienia Transparentnych Warstw Nanokompozytowych. Ph.D. Thesis, Politechnika Ślaska, Gliwice, Poland, 2018.

318. Kędzierski, K.; Suprvisory guidance Dobrzański, L.A. Charakterystyka Ekologicznych Ośrodków Polimerowych do Chłodzenia Naweglonych Stali Niskowęglowych. Ph.D. Thesis, Politechnika Śląska, Gliwice, Poland, 2017.

319. Szindler, M.; Suprvisory Guidance Dobrzański, L.A. Polimerowe Warstwy Półprzewodnikowe zol-żel do Zastosowań Fotowoltaicznych. Ph.D. Thesis, Politechnika Śląska, Gliwice, Poland, 2017.

320. Achtelik-Franczak, A.; suprvisory guidance Dobrzański, L.A. Inżynierskie Materiały Kompozytowe O Wzmocnieniu Z Mikroporowatego Tytanu Selektywnie Spiekanego Laserowo. Ph.D. Thesis, Politechnika Ślaska, Gliwice, Poland, 2016.

321. Macek, M.; Suprvisory Guidance Dobrzański, l.a. Struktura i Własności Aluminiowych Materiałów Nanokompozytowych Wzmacnianych Nanorurkami Węglowymi. Ph.D. Thesis, Politechnika Śląska, Gliwice, Poland, 2016.

322. Prokopiuk vel Prokopowicz, M.; Suprvisory Guidance Dobrzański, L.A. Wpływ zredukowanego Tlenku Grafenu na Strukture Elektrod i Własności Barwnikowych Ogniw Fotowoltaicznych. Ph.D. Thesis, Politechnika Śląska, Gliwice, Poland, 2016.

323. Czaja, I.; Suprvisory Guidance Dobrzański, L.A. Wpływ Nanodrutów i Nanoproszków Miedzi na Strukturę i Własności Nanokompozytowych Materiałów Polimerowych. Ph.D. Thesis, Politechnika Śląska, Gliwice, Poland, 2015. 
324. Hudecki, A.; Suprvisory Guidance Dobrzański, L.A. Nanowłókna kompozytowe o bioaktywnym rdzeniu i antybakteryjnej powłoce na rusztowania tkankowe. Ph.D. Thesis, Politechnika Śląska, Gliwice, Poland, 2015.

325. Mucha, A.; Suprvisory Guidance Dobrzański, L.A. Wpływ nanorurek weglowych na własności barwnikowych ogniw fotowoltaicznych. Ph.D. Thesis, Politechnika Śląska, Gliwice, Poland, 2015.

326. Górniak, M.; Suprvisory Guidance Dobrzański, L.A. Wpływ Organofilizacji Powierzchni Nanorurek Haloizytowych i Nanopłytek Montmorylonitowych na Własności Kompozytów Polimerowych. Ph.D. Thesis, Politechnika Śląska, Gliwice, Poland, 2014.

327. Szindler, M.; Suprvisory Guidance Dobrzański, L.A. Struktura i Własności Nanostrukturalnych Warstw Antyrefleksyjnych Otrzymanych Metoda ALD Oraz zol-żel na Krzemowych Ogniwach Fotowoltaicznych. Ph.D. Thesis, Politechnika Śląska, Gliwice, Poland, 2014.

328. Reimann, Ł.; Suprvisory Guidance Dobrzański, L.A. System Komputerowego Wspomagania Doboru Materiałów Na Wieloczłonowe Częściowe Stałe Protezy Stomatologiczne. Ph.D. Thesis, Politechnika Śląska, Gliwice, Poland, 2013.

329. Henderson, B. The Product Portfolio. Available online: https://www.bcg.com/publications/1970/strategy-the-product-portfolio (accessed on 8 April 2021).

330. Suresh Chandra, B.; Gopikrishna, V. (Eds.) Grossman's Endodontic Practice, 13th ed.; Wolters Kluwer: New Delhi, India, 2014; pp. $1-576$.

331. Durey, I. Deming's Management Method and Total Quality Management. Available online: https://www.gembadesk.com/ 2014/10/demings-management-method-and-total-quality-management/\#: \{\}:text=Created\%20in \%201951\%2C\%20The \%20 Deming\%20Prize\%20was\%20awarded,American\%20Society\%20for\%20Quality\%E2\%80\%99s\%20Deming\%20Medal\%20in\%20 (accessed on 17 April 2021).

332. Lina, L.R.; Ullah, H. The concept and implementation of Kaizen in organization. Int. J. Bus. Adm. Manag. Res. 2019, 19, 1-9.

333. Rokke, C.; Yadav, O.P. Challenges and Barriers to Total Quality Management: An Overview. Int. J. Performability Eng. 2012, 8, $653-665$. 